\title{
Rozdział 3 \\ Postawy kobiet i mężczyzn w różnym wieku wobec swego wyglądu
}

\subsection{Komponent poznawczy}

\subsubsection{Sposób opisywania własnego wyglądu a płeć i wiek (Julita Czernecka)}

Ciało i jego wygląd jest poddawane kontroli społecznej i społecznej „obróbce”. Jak twierdził M. Focuault, ciała zostają podporządkowane określonym normom życia społecznego, są nośnikami wielu społecznie istotnych informacji (Foucault 2000). Niemożliwe jest istnienie ciała, które niczego nam nie mówi. Cielesność zawsze jest poddawana próbie nadania jej określonych znaczeń, które odnoszą się do poszczególnych elementów ciała i jego wyglądu. Według badaczy, takich jak między innymi Daniel Hamermesh i Jeff Biddle (1994) czy Catherine Hakim (2010), we współczesnym świecie mamy do czynienia $\mathrm{z}$ upowszechnionym i uwspólnionym, bo zwesternizowanym kanonem piękna. Według nich to przede wszystkim media przyczyniły się do wypromowania identycznych wzorców w większości społeczeństw (choć nadal głównie społeczeństw zachodnich). Są to szczupła i wysportowana sylwetka, twarz o symetrycznych rysach, duże oczy i pełne usta, ładna cera, białe i proste zęby, a także muskulatura u mężczyzn oraz wąska talia i bujne, długie włosy u kobiet.

W niniejszej części książki zostanie podjęta próba opisania tego, co typowe i nietypowe $\mathrm{w}$ sposobie opisywania własnego wyglądu przez kobiety i mężczyzn $w$ różnych kategoriach wiekowych podczas wywiadów swobodnych. Niezależne od wieku czy płci badanych wypowiedzi te były skromne objętościowo, być może wynika to $\mathrm{z}$ faktu, że o samym sobie - w tym i o swoim wyglądzie - trudno jest się wypowiadać, szczególnie gdy naprzeciw nas siedzi badacz. Wypowiedzi te ograniczały się 
najczęściej do jednego, dwóch zdań na swój temat lub krótkich stwierdzeń na przykład „jestem puszysta”, „jestem wysoki”, „jestem szczupły” - mimo że wielokrotnie osoby prowadzące wywiad dopytywały badanych o podanie szczegółowego opisu. Zdecydowana większość badanych wypowiedź na temat swojego wyglądu zaczynała od opisu swojego wzrostu, budowy sylwetki, rodzaju fryzury oraz stylu ubierania się. Pojawiały się także odpowiedzi dotyczące detali twarzy, cech wyróżniających, a także odniesienia do osobowości. Udało się wychwycić istotne różnice w sposobie opisywania swojego wyglądu przez kobiety i mężczyzn w różnym wieku.

Prawie wszyscy uczestnicy badań przy opisie własnego wyglądu uwzględniali $\mathrm{w}$ pierwszej kolejności typ posiadanej przez siebie fryzury lub jej brak. Większość kobiet opisywała swoje włosy poprzez podanie informacji na temat ich koloru, długości, tego czy są farbowane lub poddawane zabiegom typu trwała ondulacja. Określając długość włosów, kobiety wskazywały, czy są one krótkie, średniej długości, półdługie, długie. Opisywały włosy jako proste lub kręcone - co nie pojawiło się w opisach u badanych mężczyzn. Panowie oprócz podawania informacji typu „fryzura krótko obcięta”, mówili także o tym, czy posiadają tak zwane „zakola”, czy mają przerzedzone włosy lub po prostu są włosów na głowie pozbawieni. Jednak warto zauważyć, że w zdecydowanie skromniejszy sposób opisywali swoje owłosienie niż czyniły to kobiety i zwracali uwagę na zdecydowanie mniejszą liczbę detali. Panie, mówiąc o swoich włosach, wspominały także o ich kolorze i odcieniach: blondynka, włosy mocno kolorowe, różowe pasemka, ciemne włosy, rude, farbowane, piękne włosy. Jedna z ze starszych kobiet, mówiąc o kolorze swoich włosów, podkreślała, że ma „piękne włosy w kolorze blond” (KST_13_85), $\mathrm{w}$ jej przypadku akcentowanie tego faktu jest jakby wyłamywaniem się z patriarchalnego modelu kobiecości, w którym tylko z młodością utożsamiona jest atrakcyjność posiadania ładnych włosów. Badane w ogóle sporadycznie mówiły o siwiźnie, nawet te najstarsze. W zasadzie tylko dwie kobiety o tym wspomniały. Natomiast panowie zwracali na to uwagę o wiele częściej, zarówno podkreślając brak siwizny lub mówiąc o niej wprost (np. o posiadaniu „szronkowatych” włosów). Zwracali także uwagę na to, że są łysi lub posiadają przerzedzone włosy.

Podstawową różnicą między kobietami i mężczyznami była obszerność opisu fryzur. Panie mówiły o objętości włosów, o tym, że mają „bujną fryzurę" oraz nawiązywały do typu uczesania. Na przykład mówiły o tym, że noszą włosy związane lub rozpuszczone, uczesane w konkretny sposób na przykład - „włosy w kok się czeszę” (KST_6_69). Badane nawiązywały do tego, czy ich fryzura jest w określonym „ładzie”, poddana dyscyplinie czy nie: „Nigdy nieuporządkowana fryzura, włosy średniej 
długości, falowane” (KSR_7_49), „Wiatr we włosach, jak to moje koleżanki nazywają, czyli nigdy nieuporządkowana fryzura, korpulentna, roztrzepana” (KSR_7_49). To, że kobiety częściej, niż mężczyźni opisują swój wygląd przez pryzmat fryzury, można wyjaśnić tym, że włosy są mocnej związane z tradycyjny modelem kobiecości. Długie, lśniące i grube włosy u kobiet symbolizują witalność, seksualność, siłę fizyczną, zdrowie, a także płodność (Skrok 2009). W tym tradycyjnym modelu o atrakcyjności kobiet i ich pozycji na rynku matrymonialnym świadczą włosy pozbawione oznak starzenia się, takich jak przerzedzenia czy siwizna. U mężczyzn z kolei, choć także włosy oznaczają witalność, młodość czy określony status społeczny, to nadawane im jest mniejsze znaczenie niż włosom kobiecym (Skrok 2009).

W wypowiedziach kobiet i mężczyzn na temat włosów możemy odnaleźć istotne różnice w odniesieniu do odmiennych kategorii wiekowych. Co ciekawe, z punktu widzenia interpretacji znaczenia włosów w tradycyjnym modelu kobiecości młode kobiety, choć wszystkie wypowiedziały się na temat swoich włosów przy opisywaniu własnego wyglądu, były one najbardziej oszczędne w tych opisach spośród wszystkich respondentek. Ich wypowiedzi były konkretne i bardzo krótkie, ograniczające się do stwierdzenia jakiej długości mają włosy oraz wskazujące kolor. W modelu kobiecości odniesionym do młodych kobiet włosy są jednym z podstawowych atrybutów atrakcyjności. Większość najmłodszych uczestniczkek wywiadów przyznała, że ma długie włosy. Włosy te były pozbawione siwizny czy innych symptomów starzenia i być może dlatego badanym nie towarzyszyła głębsza refleksja na ich temat. Żadna z młodych kobiet nie poruszała kwestii jakichkolwiek problemów z włosami przy opisie swojego wyglądu. Innego typu wypowiedzi pojawiały się w dwóch pozostałych grupach wiekowych. Najobszerniej na temat fryzur wypowiadały się kobiety w średnim wieku, mówiąc zarówno o ich długości, typie fryzury, jak i kolorze „naturalnym” lub „farbowanym”: „Mocno kolorowe, różowe pasemka” (KSR_1_38), „Blond włosy trochę rozjaśniane” (KSR_4_45), "Siwa, ufarbowana na blond” (KSR_12_6o). Kobiety w średnim wieku nie mówiły o problemach z siwieniem włosów, raczej o tym, że są farbowane - czyli o zabiegach, które czyniły włosy w jakimś sensie nadal atrakcyjnymi. Wspominały także o zmianie fryzury, o tym, że kiedyś miały dłuższe włosy, a teraz mają krótsze lub odwrotnie. Starsze kobiety poruszały częściej kwestię procesu siwienia włosów i ich przerzedzania się: „Włosy mam siwe, w sumie to białe, niefarbowane” (KST_12_84). Być może wynika to $\mathrm{z}$ naturalnego i powszechnego procesu starzenia się, pojawiania się siwych włosów lub innych problemów z nimi związanych.

Podobna sytuacja miała miejsce w przypadku mężczyzn. Ci najmłodsi, choć także stanowili najliczniejszą grupę poruszającą kwestię fryzury 
w swoim opisie, to jednak byli najoszczędniejsi w tych wypowiedziach. Włosy są dla nich (tak jak dla młodych kobiet) ważnym elementem wyglądu, co może świadczyć o procesie większej androgynizacji tej kategorii wiekowej mężczyzn. Z kolei panowie w średnim wieku zazwyczaj mówili o kolorze włosów i siwiźnie lub jej braku. Być może wiek średni tak jak w przypadku kobiet jest wiekiem, w którym zauważa się pierwsze symptomy starzenia się. Niektórzy respondenci podkreślali to, że siwizny jeszcze nie zauważają, mimo upływającego czasu: „Nie siwy, włosy - ciemny blond” (MSR_6_47), „Ciemny, że włosy mam ciemne, powiedzmy, że jak na swój wiek. Co poniektórzy mówią - o stary, ciebie jeszcze siwizna nie dopadła. Istotnie, takich problemów jeszcze nie mam" (MSR_8_53). Tylko kilku starych mężczyzn powiedziało o swojej siwiźnie. Większość najstarszych respondentów wskazało jednak przede wszystkim na problem $\mathrm{z}$ łysieniem (tylko jeden mężczyzna zaznaczył, że nie ma tego problemu, bo ma jeszcze gęste włosy). Włosy okazują się także być ważnym aspektem wyglądu uwzględnianym przez mężczyzn, mimo że nie wpisują się w tradycyjny model męskości. Może to świadczyć o zmianach, jakie przechodzi we współczesnym społeczeństwie wizerunek mężczyzny. Ciało męskie także ulega uprzedmiotowieniu, ma być atrakcyjne i tak jest prezentowane w przekazach kulturowych - choćby w reklamach sporadycznie widzimy mężczyzn łysych (por. Arcimowicz 2003, Melosik 2006). Poza tym posiadanie włosów przez mężczyzn jest często utożsamiane z byciem postrzeganym jako „młodym” lub wręcz odwrotnie - już „niemłodym”.

Choć wśród młodych ludzi zdecydowanie najczęściej w wypowiedziach jako atrybut własnego wyglądu zewnętrznego pojawiały się włosy, to zarówno młode kobiety, jak i młodzi mężczyźni w dość oszczędny sposób wypowiadali się na ich temat. Kobiety i mężczyźni w kategorii wiekowej 20-37 lat mówili najczęściej o ich długości i typie fryzury, nie było tutaj znaczących różnic. Kobiety w średnim wieku dość obszernie wypowiadały się na temat swoich włosów, mówiąc o ich kolorze, tym, czy są farbowane czy nie, długie czy krótkie, bujne czy nie (warto zauważyć, że w tej kategorii wiekowej tylko jedna pani nawiązała do siwizny). W przypadku panów w tym samym wieku najczęściej mówili o sposobie, w jaki są ostrzyżeni i jak układają włosy, czy mają zakola czy są łysi, nawiązywali także do przerzedzania się włosów. Ciekawe jest to, że wielu przyznawało, że ich atrybutem jest brak siwizny. Najstarsze badane mówiły przede wszystkim o farbowaniu włosów, ich długości i sposobie układania. Ze względu na specyfikę badanej grupy (osoby starsze), brak lub występowanie siwych włosów było kategorią z dość liczną liczbą wskazań, choć zdecydowanie częściej u starych mężczyzn niż kobiet. Panowie mówili także o problemie łysienia. Należy zwrócić uwagę, że 
współcześnie obowiązujący kult młodości nie dotyczy tylko kobiet, ale także - być może coraz silniej - mężczyzn.

Kolejnym aspektem wymienianym przy opisie własnego wyglądu przez zdecydowaną większość badanych - niezależnie od wieku i płci - była budowa ciała i wzrost. Tę cechę najczęściej opisywano w sposób bardzo konkretny za pomocą określeń: wysoki/-a, średniego wzrostu lub niski/-a. Tylko niektórzy badani podawali wzrost w centymetrach lub metrach. Najliczniej wypowiadającą się na temat wzrostu wśród kobiet grupą wiekową były najmłodsze respondentki. Tylko jedna $\mathrm{z}$ nich podkreśliła, że wzrost jest jej cechą wyróżniającą: „Jestem troszkę wyższa, znaczy niż przeciętne dziewczyny są” (KM_3_24). W tradycyjnym modelu kobiecości niższy lub średni wzrost jest atrakcyjniejszy, niż „zbyt wysoki”. Dzieje się tak dlatego, że mężczyźni zazwyczaj na partnerki życiowe wybierają kobiety niższe od siebie. Niski wzrost oraz delikatna budowa ciała są dla nich bardziej atrakcyjne (Barbee, Cunningham i in. 1995). Być może w społeczeństwie patriarchalnym utożsamiane jest to $\mathrm{z}$ większą zależnością i uległością wobec mężczyzny. Warto zauważyć, że dwie kobiety spośród najstarszych respondentek podkreśliły, że kiedyś były wyższe, ale wraz z upływem wieku ten wzrost uległ zmianie: „Wzrost, kiedyś był wyższy, ale już się trochę skurczyłam, czyli w tej chwili jako średni” (KST_9_71), „Jestem teraz już niska” (KST_14_86). W tym kontekście badani dostrzegli proces starzenia się ciała, a zatem jego „kurczenia się”, obniżania wzrostu. Jeśli chodzi o panów, to również najczęściej wypowiadającą się na temat wzrostu grupą wiekową byli młodzi mężczyźni. Najliczniejsza grupa mężczyzn w wieku 20-37 lat określała siebie jako osoby wysokie lub średniego wzrostu. Natomiast ci, którzy uważali siebie za niewysokich, częściej podawali dokładną miarę w centymetrach. Warto zauważyć, że tak jak najmłodsi badani najliczniej opisywali siebie jako wysokich, tak starsi zazwyczaj jako niskich lub średniego wzrostu. Należy podkreślić, że wzrost u mężczyzn jest silnie związany z posiadaniem autorytetu. Im wyższy mężczyzna, tym cieszy się większym społecznym uznaniem (Gladwell 2008). Ponadto wysoki wzrost jest także utożsamiany z młodością. Ciało w procesie starzenia niejednokrotnie ulega skróceniu. Chyba powinien być przecinek przed niż, bo jest czasownik później. Zwłaszcza, że wzrost jest silnie utożsamiany z tradycyjnym modelem męskości.

Budowa ciała - to kolejny aspekt, na temat którego wypowiadali się respondenci. W przypadku kobiet i mężczyzn najwięcej osób w średnim wieku poruszyło tą kwestię. Jeśli chodzi o kobiety, to mówiąc o swojej sylwetce, opisywały ją jako normalną i średnią, szczupłą lub raczej szczupłą. Oto pełniejsza wypowiedź jednej z nich: „Żeby mnie rozpoznać, jeżeli już by mnie ktoś dopytywał, czy jestem gruba 
czy chuda, to powiedziałabym średniej budowy ciała, tak czyli ani nie gruba, ani nie chuda" (KSR_5_47). W grupie wypowiadających się kobiet pojawiły się także odniesienia do posiadania „pełnych kształtów i „kształtów kobiecych”. Tylko jedna kobieta określiła się mianem „filigranowej". I także jedna badana opisała swój wygląd zewnętrzny, charakteryzując szczegółowo poszczególne elementy swojego ciała, w tym atrybuty i mankamenty sylwetki kobiecej: „Mam bardzo chude ręce, trochę większe biodra, biust średniej wielkości, no jakieś tam wcięcie w talii, nogi proste i długie, cellulit" (KM_8_29). W modelu tradycyjnej kobiecości talia u kobiety ma być wąska, a biodra szerokie - takie kobiety są uważane za atrakcyjne. Szerokie biodra utożsamiane są z wyższymi możliwościami reprodukcyjnymi i tym samym ich właścicielki są atrakcyjniejsze seksualnie dla mężczyzn (Singh 1993). W tym przypadku okazuje się, że kobiety w średnim wieku najbardziej wpisują się w ten element tradycyjnego modelu kobiecości, jeśli chodzi o sylwetkę. Należy jednak pamiętać, że w tym kontekście to przede wszystkim młodość jest uważana za atrakcyjną, nie sam wygląd ciała. Jeśli chodzi o mężczyzn, to zwykle opisywali siebie, nawiązując do tego, że są szczupli, średniej, normalnej lub atletycznej budowy ciała. Mówili także o proporcjach sylwetki i stopniu jej wysportowania: „Po prostu szczupła sylwetka, akurat jeśli chodzi o moją sylwetkę, to nie wyróżniam się czymś szczególnym, jest po prostu szczupła sylwetka nic więcej (MSR_1_38). Powiedziałbym, poinformowałbym o średniej budowie ciała (MSR_4_40). Atletycznie zbudowany (MSR_9_54). Ani za gruby, ani za chudy, taki normalny jestem" (MST_8_70). Niektórzy starsi mężczyźni zwracali uwagę na swoją postawę i to, że mimo wieku ich ciało jest wyprostowane.

Niezależnie od wieku kobiety zwracały uwagę na swoją sylwetkę i tuszę. Częściej niż mężczyźni, mówiły o tym, że są „przy kości”. Na uwagę jednak zasługuje fakt, że w przypadku kobiet młodych częściej było to raczej związane $\mathrm{z}$ negatywną oceną: „Jestem grubsza troszkę [...], taka bardziej okrągła niż większość dziewczyn w moim wieku” (KM_3_24), „Jestem osobą przy kości [...] trochę za dużo mnie" (KM_13_34). Warto zauważyć, że wśród młodszych uczestniczek badania dominowały opinie o byciu szczupłą lub normalnej, przeciętej budowy. Może to być związane $\mathrm{z}$ większym przywiązywaniem wagi do wyglądu, dbaniem o to, by być szczupłym, ponieważ szczupła sylwetka jest obecnie lansowana $\mathrm{w}$ środkach masowego przekazu, szczególnie tych skierowanych do młodych kobiet. Ponadto wizja szczupłego ciała jest wzmacniana przez przypisywanie pozytywnych cech osobom szczupłym, takich jak sukces zawodowy, atrakcyjność seksualna, zdrowie oraz posiadanie kontroli nad własnym życiem. Osoby otyłe i z nadwagą są postrzegane jako niechlujne, 
leniwe, zaniedbane, które nie potrafią kontrolować własnego ciała i nie mogą wpływać na swoje życie (Melosik 1996).

Z kolei kobiety w średnim wieku i starsze podkreślały także pozytywne aspekty posiadania - jak to określały - bardziej kobiecych kształtów: „Mam kształty kobiece, ale nie jestem gruba” (KSR_1_38), „Raczej jestem dobrze zbudowana z niezłymi nogami” (KST_5_67). Jedna z nich połączyła bycie osobą "puszystą" z byciem zadowoloną z życia i uśmiechniętą. Jednocześnie na uwagę zasługuje fakt, że kobiety starsze najczęściej opisywały siebie jako pulchne lub z nadwagą, zaznaczając także tym samym te elementy swojego ciała, które o tym świadczą: „Można powiedzieć, że coś przytyłam, ale jestem średniej tuszy” (KST_16_89), „Niestety jestem dość pulchna, to mi też przeszkadza w aktywności życiowej i w ogóle, frustruje, bo większość życia byłam osobą szczupłą” (KST_9_71), „Tak, tutaj tak (pokazuje na brzuch - przyp. aut.), wałeczek i oponka się robi” (KST_1_64). Im badane były starsze, tym „bycie przy kości” częściej było postrzegane jako zaleta lub cecha neutralna niż wada czy mankament. Być może kobiety stare lub starzejące się "nie muszą” już - w swojej opinii - być szczupłe, a atrakcyjność jest także przez nie utożsamiana $\mathrm{z}$ „kobiecymi", czyli bardziej obłymi kształtami ciała.

Jeśli chodzi o mężczyzn, to młodzi respondenci byli skłonni opisywać swoją sylwetkę jako szczupłą (nieliczni przyznali się do nadwagi). Pojawiały się także wypowiedzi na temat umięśnionego ciała: „Opisałbym siebie jako osobę [...], z taką wydaje mi się atletyczną budową ciała, raczej staram się chodzić prosto [...], szczupła atletyczna budowa" (MM_4_24). Warto zauważyć, że mężczyźni w średnim wieku także wskazywali na ten typ posiadanej przez siebie sylwetki. Jednak niektórzy z tej kategorii wiekowej starali się podkreślić wysiłek, nakład pracy, jaki muszą włożyć w to, by wyglądać w taki sposób: „Super wysportowany, przystojny, dbający o siebie, schludny, sprawiający dobre wrażenie” (MSR_5_46), „Mam mocną budowę i ja dużo ważę, chociaż tego nie widać, ale to jest kwestia budowy posportowej" (MSR_12_58). Mówili także o uprawianiu sportu czy stosowaniu diety. Wśród mężczyzn w średnim wieku pojawiała się także w opisie kwestia posiadania lub nieposiadania tak zwanego „brzuszka”: „Facet z lekkim brzuszkiem” (MSR_2_39), „Nie z dużym brzuchem” (MSR_6_47), „Brzucha dużego nie mam” (MSR_13_6o). Jeden $z$ wypowiadających się mężczyzn opowiedział o niekorzystnych zmianach, jakie zaszły w jego wyglądzie po ukończeniu przez niego pięćdziesięciu lat:

Do pięćdziesiątego roku życia ważyłem 56 kilo i miałem w pasie $76-78$ do $80 \mathrm{~cm}$, czyli byłem bardzo szczupły. W tej chwili, po chorobie, mam 86 kilo i to jest strasznie dużo, a w pasie to nie wiem, ale bardzo dużo. Tak, że to jest zupełnie inna sylwetka, inna postać, ale tak jak mówię, mi to 
zupełnie nie przeszkadza, traktuje to, że tak musi być i koniec, o, na tej zasadzie (MSR_15_61).

Z powyższych wypowiedzi wynika, że dla mężczyzn i młodych, i w średnim wieku, sylwetka jest istotna. Natomiast najstarsi mężczyźni sporadycznie odnosili się w swoich wypowiedziach do swojej sylwetki. Tylko jeden stwierdził, że jest „w miarę przystojny” (MST_1_63). Inni mówili najczęściej, że są „ani grubi, ani chudzi”. Dwóch stwierdziło, że są nieatrakcyjnej budowy - jeden przyznał, że jest „zniszczony przez życie” (MST_14_82), a drugi, że jest „niski, nieładny, nieatrakcyjny” (MST_10_71). W tradycyjnym modelu męskości mężczyzna powinien być raczej wysoki i umięśniony, posiadać wąskie biodra w stosunku do szerokich barków (por. Melosik 2006). Posiadanie „brzuszka” oznacza utratę tego męskiego, silnego ciała - świadczy raczej o zaniedbaniu się lub procesie starzenia.

Podsumowując kwestie opisywania przez respondentów sylwetki, to młode osoby, zarówno kobiety, jak i mężczyźni, opisując siebie, najczęściej wskazywali na to, że są szczupli. Dodatkowo najmłodsi mężczyźni chwalili się swoją atletyczną budową ciała. Niewiele było wypowiedzi w tej kategorii wiekowej o posiadanej nadwadze. Być może jest to związane z tym, że młodzi ludzie przywiązują dużą wagę do własnego wyglądu w kontekście lansowanego w mediach kultu młodych i szczupłych ciał. A może być też tak, że akurat w tej grupie badanych nie znalazł się nikt, z problemem znaczącej nadwagi. Natomiast wśród osób w średnim wieku, panie podkreślały posiadanie tak zwanych „kobiecych kształtów”, a panowie mówili o normalnej budowie ciała lub posiadaniu niewielkiego „brzuszka”. Najstarsze badane kobiety opisywały się częściej jako te z nadwagą, ale raczej akceptujące swój wygląd. Z kolei panowie w tym wieku, albo mówili, że są „normalnej” budowy, albo że są nieatrakcyjni. Im respondenci byli starsi, tym częściej mówili o tym, że utracili atrakcyjną sylwetkę, którą kiedyś posiadali. Tym samym większość z nich utożsamia starość z brakiem atrakcyjności. Choć oczywiście te badania wskazują, że są także odstępstwa od tego sposobu myślenia.

Kolejnym aspektem wymienianym przy definiowaniu własnego wyglądu były detale twarzy. Badane osoby wymieniały między innymi kolor oczu, noszone przez siebie akcesoria, wyraz twarzy i kilka innych elementów. Występowały dwie istotne cechy różnicujące płeć w sposobie opisywania twarzy - kobiety zwracały uwagę na makijaż, a mężczyźni na zarost na twarzy. Opisując swoją twarz, uczestniczki badania często nawiązywały do robienia lub nierobienia makijażu: „Oczy umalowane trochę, maluję się, owszem, jakoś tam jeszcze mi się udaje, bo niektórzy nie umieją tego robić” (KST_6_69), „Nie maluję się, nie będę umalowana, taka saute" (KST_7_7o). Warto zauważyć, że na temat makijażu wypowiadały się 
kobiety tylko te należące do grupy młodych i starych, te w średnim wieku nie poruszały tego tematu. Często kobieca twarz, która jest całkowicie naturalna, bywa postrzegana jako nieatrakcyjna. Nawet w przypadku młodych kobiet delikatny makijaż powoduje, że same postrzegają się jako atrakcyjniejsze i tak samo są postrzegane przez otoczenie (Kowalczyk 200o). Makijaż odgrywa rolę mediatora pomiędzy naturą a kulturą: „,malowidła na twarzy nadają przede wszystkim danej osobie godność istoty ludzkiej - stwierdzają przejście od natury do kultury" (Radkowska 1999: 34). W kontekście kobiet można by pokusić się o tezę, że dzięki makijażowi stają się bardziej „społecznie widoczne”. Z jednej strony wpływa to na ich upodmiotowione, bo same decydują o tym, czy makijaż stosują, czy nie, i jak on wygląda. To z kolei wpływa na to, że są bardziej lub mniej "zauważalne", same decydują o swoim wizerunku i o tym, jak chcą być postrzegane przez otoczenie. Jednak z drugiej strony są bardziej przedmiotowo traktowane przez innych, choćby w kontekście seksualnej atrakcyjności lub jej braku. Być może młode kobiety makijażem chcą zwiększyć swoją efektowność. W przypadku starych kobiet makijaż staje się dla nich narzędziem zachowania atrakcyjnego i młodszego wyglądu, nieodłącznym atrybutem zachowania kobiecości i bycia dostrzeganą przez otoczenie. Jedna z wypowiadających się kobiet stwierdziła, że w makijażu czuje się pewniej i jest lepiej także postrzegana przez inne osoby:

Troszeczkę sobie oko umaluję, czy make-up jakiś zrobię na twarz, ale bardzo lekki, bo nie jestem osobą preferującą nakładanie dużej ilości tych sztucznych rzeczy, bo ja nie jestem z tego pokolenia, tym niemniej lubię ładnie wyglądać, nie wyjdę nigdy bez umalowanych ust na ulicę, mam taki nawyk czy przyzwyczajenie i to mi dodaje trochę blasku (KST_2_64).

Co ciekawe, młode kobiety, opisując poszczególne elementy twarzy, zwracały uwagę na to, że mają na przykład prosty nos, okrągłą twarz, jasną cerę czy duże usta. Dwie młode kobiety wypowiedziały się na temat swojej urody w sposób oceniający: „mam ładną twarz” (KM_13_34), „mam grecka urodę" (KM_12_34). Kobiety stare opisywały stan swojej cery, zwracając szczególną uwagę na zmiany skórne związane z procesem starzenia się, takie jak zmarszczki, worki pod oczami lub ich brak:

W miarę zadbana, bym powiedziała, nie powiem, że jestem jakaś wiotka, bo to już lata, zmiany hormonalne, ale twarz mam bez zmarszczek, w związku z tym to świadczy o tym, że te osoby nie dają mi takiego wieku, w jakim jestem rzeczywiście, bo buzię mam gładką tak jakbym botoksu używała, chociaż zastrzegam, że nie używam tego rodzaju zabiegów w ogóle (KST_2_64). Oczy są już troszkę podkreślone, podworkowate już, pod oczami woreczki są (KST_14_86). 
W patriarchalnym modelu kobiecości kobieta młoda z zasady jest atrakcyjna, zatem takie atrybuty urody jak pełne usta, gładka i jasna cera, brak zmarszczek świadczą o atrakcyjności, a posiadanie zmarszczek czy worków pod oczami o jej utracie. Wydaje się, że uczestniczki badania zdają sobie z tego sprawę.

Panowie $\mathrm{z}$ kolei $\mathrm{w}$ opisie twarzy nawiązywali do spraw związanych z zarostem, karnacją, kolorem oczu, posiadaniem zmarszczek. Ci w średnim wieku na ogół wspominali właśnie o zaroście: „Golę się, bo muszę, ale mnie to denerwuje” (MSR_3_40), „Noszę wąsy, w związku z tym jest to charakterystyczna rzecz, że tam mam krótki wąs" (MSR_8_53). Niektórzy młodzi mężczyźni, posiadający ciemną karnację, także o niej wspominali, co nie zdarzało się w przypadku tych, którzy mieli ją jaśniejszą: „Mam ciemną cerę, podobno wyglądam, jakbym przyjechał z południa Europy" (MM_6_27), „Mam ciemną opaleniznę, karnację” (MM_6_27). Ciemna karnacja oraz posiadanie zarostu wpisuje się $\mathrm{w}$ tradycyjny model męskości. Panowie na ogół wskazywali także posiadanie tak zwanych „męskich rysów twarzy”. Opisywali także z większą uważnością niż czyniły to kobiety wyróżniające ich elementy twarzy: „Mam duży nos” (MM_3_22), „Pociągłą twarz, lekki zarost, spory nos, głęboko osadzone oczy” (MSR_1_38), „Mam wysokie czoło, bardzo wysokie czoło” (MSR_11_57), „Z odstającymi uszami, $z$ wielkim nosem” (MSR_15_61). Z tych krótkich wypowiedzi można wywnioskować, że mężczyźni są częściej niż kobiety, krytyczniej nastawieni do oceny swojego wyglądu, natomiast kobiety opisują siebie w bardziej neutralny lub pozytywny sposób. Z kolei starzy mężczyźni wskazywali raczej na swoje zmarszczki jako jedną z cech wyróżniających: „No już zmarszczki mam, no ta twarz już nie taka młoda, jak to w starym wieku się ma" (MST_8_70), a także na stan uzębienia: „Szczerbaty, przepraszam, bo zębów nie mam, jeden jedyny ząb mam, protezę mam górną, a dolnej to w ogóle nie noszę" (MST_14_82). Inni zwrócili uwagę na proces starzenia się, odnosząc się do siwienia wąsów i włosów. Tylko jeden starszy mężczyzna spośród wszystkich innych opisał siebie jako w „miarę przystojnego” (MST_1_63). W społeczeństwie patriarchalnym siwienie czy posiadanie zmarszczek świadczyło u mężczyzn o ich dojrzałości, ugruntowanej społecznej pozycji, dziś natomiast, w czasach dyktatu młodości, także mężczyźni zaczynają coraz większą uwagę przykładać do swojego wyglądu i oceniać także w kontekście procesu starzenia się.

Tylko jedna kobieta i jeden mężczyzna zwrócili uwagę na rodzaj swojego spojrzenia. Ona stwierdziła, że ma "powalające spojrzenie” (KM_11_34), a on stwierdził, że ma smutne i przenikliwie patrzące oczy i że czasami „zabija wzrokiem” (MSR_3_40). Obie te wypowiedzi można zinterpretować w kontekście modelu patriarchalnego kobiecości i mę- 
skości. Bowiem w „jej” kontekście chodziło o takie spojrzenie o konotacji seksualnej, bycia atrakcyjną, a w ,jego" przypadku raczej chodziło o aspekt bycia niedostępnym, „bycia twardzielem”. Młodzi mężczyźni nawiązywali w opisie swojego wyglądu także do koloru oczu jako cesze ich wyróżniającej. Panowie w średnim wieku i starsi nie odnieśli się do tego aspektu. Być może świadczy to o większej androgyniczności młodych mężczyzn, bo na kolor oczu zwracały przede wszystkim uwagę kobiety.

Cechy osobowości, chociaż nie są bezpośrednio związane $\mathrm{z}$ wyglądem zewnętrznym, zostały jednak uwzględnione przez część respondentów przy jego opisie. Większość wypowiadających się na ten temat osób była w średnim i starszym wieku. Najczęściej wymieniano pogodny wyraz twarzy i towarzyszący mu uśmiech: „Od rana do wieczora mogę się śmiać, że jestem zawsze uśmiechnięta, pozytywna” (KSR_13_61). „O twarzy, no może nie ślicznej, ale sympatycznej, szerokim uśmiechu” (KST_8_70). „Banan na twarzy, uśmiech znaczy, cały czas uśmiechnięty” (MM_2_22). „Cały czas jestem uśmiechnięty, zadowolony, tryskający humorem” (MSR_9_54). Warto zauważyć, że w teorii C. Hakim urok i wdzięk, a także pozytywna energia oraz „bycie duszą towarzystwa” powodują, że ludzie uśmiechnięci, pogodni są postrzegani jako bardziej atrakcyjni (Hakim 2010). Być może kiedy atrakcyjność w wymiarze fizycznym przemija, ważne jest zachowanie wysokiej atrakcyjności społecznej, a ludzie pozytywni, uśmiechnięci są lepiej postrzegani przez otoczenie. Badane osoby opisywały siebie także poprzez własny temperament: „Jestem energiczna, to znaczy chodzę dosyć temperamentnie, można mnie po chodzie poznać również" (KM_15_36). Niektóre kobiety w średnim wieku i starsze także mówiły, że są "gadatliwe”, „otwarte”, aktywne ruchowo. Starość na ogół kojarzy się z powolnością, opieszałością, niezdarnością, a ruchliwość, otwartość, zwinność przypisywana jest młodości (por. Trafiałek 2003; Szatur-Jaworska 2005). Może właśnie ze względu na to, niektóre uczestniczki badania podkreślały właśnie te cechy, które zapewniały im jakby „kontynuację” bycia młodą - na przekór metryce.

Panowie $\mathrm{w}$ średnim wieku odwoływali się przy opisie samych siebie także do tego, że sprawiają dobre wrażenie, są schludni, wyglądają inteligentnie - jak osoby wykształcone: „Dbający o siebie, schludny, sprawiający dobre wrażenie” (MSR_5_46), „To, z czym ja się spotkałem, trochę zaskakujące, powiedziano mi, że wyglądam jak idę gdzieś jak matematyk, jako osoba wykształcona, inteligentna" (MSR_14_61). W dominującym dyskursie ubiór mężczyzny odzwierciedla osobowość, stanowczość, stabilność emocjonalną, racjonalność, mężczyzna ma być także inteligentny i wykształcony (Melosik 2006). Klasyczny strój nawiązuje do kanonu wizerunku mężczyzny obowiązującym w społeczeństwie patriarchalnym. 
W opisach wyglądu pojawiło się także nawiązanie do wieku. Jednak te wypowiedzi nie były tak liczne jak w poprzednich kategoriach opisu. Kobiety zazwyczaj podkreślały, że wyglądają młodziej niż wskazuje na to ich metryka:

Atrakcyjna [...] taka młodsza niż wskazuje na to metryka (K_15_36). Nie wyglądam na swoje lata i bardzo wiele osób mi mówi, że mimo że w tej chwili mam 64 lata, to nikt nie określa mnie w takim przedziale wieku tylko mówią, że wyglądam o wiele lepiej, czyli wyglądam gdzieś na 55 lat (KST_2_64). Ja bym się określiła gdzieś tak do 75 lat, bo tak się czuję [...]. Nie jestem brzydka, jestem blondynką, mam piękne włosy, ładny kolor blond, oczy niebieskie, jestem interesującą kobietą po prostu (KST_13_85).

I znowu młodszy wygląd staje się w interpretacji badanych synonimem atrakcyjności. Co ciekawe, wspominały o tym przede wszystkim młode badane oraz te najstarsze. Z kolei uczestniczki badania w wieku 38-62 lata po prostu definiowały siebie jako „kobiety w średnim wieku”. Natomiast wypowiadający się na ten temat mężczyźni raczej podkreślali wiek w kontekście procesu starzenia się. Jeden z badanych uważa, że wygląda na starszego niż jest w rzeczywistości „Wysoki, łysy, to już można sobie pomyśleć "a, po czterdziestce"” (MM_13_32). Pozostali z kolei stwierdzili, że się już „zestarzeli”: „W tej chwili to widzę jak patrzę w lustro to już ta moja osoba, wygląd mój się już zestarzał” (MSR_15_61), „Raczej bym powiedział, że niestety już zaczynam się jakoś już pochylać jak gdyby, starzeć" (MST_13_77). Jak wynika z powyższych wypowiedzi, kobiety raczej podkreślały młodszy wygląd i swoją atrakcyjność, mężczyźni wręcz przeciwnie - zwracali uwagę na niekorzystny proces starzenia się i stawanie się nieatrakcyjnym. Może to świadczyć o procesie uwrażliwiania się mężczyzn na wygląd i jego dbanie, co do tej pory stanowiło domenę kobiet.

Ubiór także stanowił element charakteryzowania siebie. Większość badanych opisała, w jaki sposób się ubiera. Prawie wszystkie kobiety wypowiadające się na ten temat nawiązywały do sportowego stylu, który zapewnia, że czują się w nim komfortowo:

(Mój styl ubierania się jest - przyp. aut.) młodzieżowy i elegancki jednocześnie (KM_1_21). Może jeszcze ubranie mogłabym opisać w ostateczności. To beżowa spódnica, jasna bluzką z jakąś naprasowanką na przodzie i ciemny makijaż i fioletowa torebka (KM_3_24). Ubrana w jeansy, ubrana w stylu nie tyle co sportowym, a raczej luźnym, jakieś jeansy i t-shirt, teraz, bo jest lato, np. sandałki czy jakieś klapki (KM_14_35). Na pewno nie modnie ubrana, tylko wygodnie (KSR_7_49).

Jedyna $\mathrm{z}$ wypowiadających się $\mathrm{w}$ tym kontekście pań w starszym wieku stwierdziła, że ubierając się w spodnie, t-shirt czy sportowe bluzki, 
ubiera się niestosowane do swojego wieku (KST_7_7o). Warto zauważyć, że kobiety w średnim wieku podkreślały nie tylko wygodę, ale to, że zaczęły się ubierać modniej oraz bardziej kolorowo: „Ubieram się dosyć barwnie i kolorowo, więc niewątpliwie opisałabym swój strój” (KSR_11_60), "Jeszcze do niedawna chodziłam bardzo na czarno, teraz zaczynam się ubierać się kolorowo" (KSR_8_53). Jeśli chodzi o strój, to te ubrania, które uważane są za klasyczne, konserwatywne, eleganckie na ogół świadczą o konformizmie społecznym, a te sportowe, komfortowe przypisuje się nonkonformizmowi (Bokszańska 2004). Ma to szczególne znaczenie w przypadku osób starszych, które zazwyczaj są postrzegane jako bardziej konserwatywne. Sportowy styl cechujący kobiety w średnim wieku oraz te najstarsze, a także bardziej kolorowy u kobiet w średnim wieku, może świadczyć o „wyłamywaniu się" tych kobiet $\mathrm{z}$ tradycyjnego modelu kobiecości, w którym kobieta powinna być bardziej elegancka, a jej stroje winny bazować na sukienkach, butach na wysokim obcasie i podkreślającym „atuty kobiecego ciała” kroju ubrań (biust, talię, biodra). Kobiety w średnim wieku - poprzez wielobarwny strój, być może chcą być nadal widoczne społecznie, dostrzegane przez otoczenie (nie tylko młode dziewczyny). Z kolei niektóre młode uczestniczki badania, oprócz podkreślania także znaczenia komfortu w sposobie ubierania się, zwracały uwagę na jego oryginalność: „Czerwona kurtka w dosyć dziwnym kroju, który będzie się zapewne rzucał w oczy, gdybyśmy sobie stali w jakiejś grupie. Buty na obcasie (KM_4_27), „(jestem - przyp. aut.) raczej zwracająca uwagę ze względu może na mniej standardowy sposób ubierania" (K_15_36). Reprezentantki najmłodszej kategorii badanych w swoich wypowiedziach częściej uwzględniały także elementy stroju, które miały je wyróżniać spośród innych, przywiązywały większą uwagę do mody i dostosowania ubioru do swojego wieku. Starsze respondentki wyłamywały się z takiego typowego dla patriarchalnego sposobu postrzegania kobiet w ich wieku - stawiały na własną wygodę lub kolorowym strojem chciały zwrócić na siebie uwagę (w patriarchacie powinny być raczej ubrane w stonowany, nierzucający się w oczy strój, „stosowny” do ich wieku).

W przypadku mężczyzn najliczniej na temat stroju wypowiedzieli się młodzi. Zarówno uczestnicy badań z najmłodszej, ale i najstarszej kategorii często opisywali strój jako młodzieżowy, luźny i sportowy:

Często chodzę w koszulach [...], raczej luźna koszula, rozpięta, taka na luzie. Nie jakaś upięta, bez krawatu. Nic takiego. Buty raczej sportowe. [...] wydaje mi się, że luźny styl ubierania, taki młodzieżowy, można to nazwać młodzieżowym stylem ubierania (MM_4_24). Staram się ubierać tak po młodzieżowemu, wydaje mi się, że to teź świadczy o tym że czuję się młodo, że lubię się ubierać bardziej młodzieżowo niż w stylu »na tatusia«, ja to tak nazywam 
(MM_15_37). Ubierający się młodzieżowo (MST_6_66). Granatowa bluza sportowa i czerwona reklamówka (MST_12_72).

Tylko jeden mężczyzna w średnim wieku stwierdził, że ubiera się młodzieżowo, ale tak, aby „nie przesadzić” i „żeby nie zrobić z siebie playboya młodzieżowego” (MSR_6_47). Większość panów w średnim wieku skłaniała (nie wiem czy forma dobra) się do tego, by wyglądać bardziej elegancko i ubierać się stosownie do okazji: „W miarę elegancko, estetycznie ubrany” (MSR_14_61), „Niekoniecznie krawat, ale jakiś element czegoś eleganckiego powinien być. Jeżeli byłaby to okazja formalna, to byłby strój dostosowany do okazji” (MSR_14_61). W przypadku mężczyzn daje się uchwycić w ich wypowiedziach nawiązanie do tradycyjnego modelu męskości. Młodość może pozwolić sobie na „luz”, wiek dojrzały powinien bazować na elegancji, stonowaniu, racjonalności w doborze stroju.

W kontekście porównania płci, to zarówno młode kobiety i młodzi mężczyźni cenili komfort, sportowe ubrania, ale także ich oryginalny wygląd. Opisywali siebie poprzez ubieranie się w modne „ciuchy”. Kobiety w średnim wieku przywiązywały większą wagę do wyróżniania się kolorowym strojem, a ich rówieśnicy - elegancją. Osób starszych wypowiadających się na ten temat były łącznie tylko trzy osoby, więc trudno tu o uchwycenie istotnych różnic między płciami.

Reasumując, w opisie własnego wyglądu dokonywanym przez uczestników i uczestniczki badania, możemy odnaleźć elementy zarówno wpisujące się w model kobiecości i męskości funkcjonujący w społeczeństwie patriarchalnym, jak i nowoczesnym. Po pierwsze kobiety odwołują się do takich swoich cech, które utożsamiane są z tradycyjnym modelem kobiecości: długie włosy pozbawione siwizny, ładna, gładka cera, „kobiece” kształty sylwetki (wąska talia, szerokie biodra, obfity biust). Warto podkreślić, że zwracały na to uwagę respondentki w różnym wieku. Te młode wypowiadały się na ten temat w najskromniejszy sposób, być może dlatego, że to właśnie młodość ich ciała pozbawiała je głębszej refleksji na temat swojego wyglądu w tym kontekście. Przyjmowały go jako coś „naturalnego” - są młode, więc atrakcyjne, mają pełne usta, gładką cerę, gęste i długie włosy, szczupłą sylwetkę. Z kolei takie cechy jak na przykład „bycie przy kości” czy zbyt wysoki wzrost były traktowane jako odstępstwa od normy dla tej kategorii wiekowej lub kobiecości w ogóle. Wraz z wiekiem uczestniczki badania jednak charakteryzowała większa refleksyjność i wnikliwsze rozważania przy opisywaniu własnego wyglądu. Podkreślały te atrybuty, które wpisują się w tradycyjny model kobiecości (bycia atrakcyjną), czyli posiadanie nadal ładnych włosów, pozbawionych siwizny, farbowanych. Wyróżnianie się posiadaniem „kobiecej sylwetki”, według tych pań jest ich atutem - czyli nie są „ani grube, ani chude”, mają widocznie zarysowaną linię biustu i bioder. Kobiety w średnim wieku 
i starsze zwracały także uwagę na jakość swojej cery, niektóre podkreślając fakt, że nie mają jeszcze zbyt widocznych zmarszczek i - w niektórych przypadkach - że wyglądają na młodsze niż wskazuje na to ich metryka. Istotne wydaje się także to, że kobiety w średnim wieku, by być zauważonymi przez otoczenie jako kobiety, zakładały kolorowe, wyróżniające ich ubrania. A kobiety stare stosowały makijaż jako narzędzie podnoszenia swojej atrakcyjności i zachowania młodego wyglądu. Z drugiej strony możemy zauważyć także elementy nowoczesnego modelu kobiecości choćby w kontekście wybierania przez większość uczestniczek badania wygodnych, komfortowych strojów, a nie tych "typowo kobiecych”, takich jak sukienki czy buty na wysokim obcasie.

Jeśli chodzi o mężczyzn biorących udział w badaniu, to również możemy dostrzec wspólistnienie tych dwóch modeli męskości. Z jednej strony mówili o wzroście, budowie ciała czy męskich rysach twarzy, ciemnej karnacji i posiadanym zaroście, klasycznym ubiorze, czyli cechach wpisujących się częściej w patriarchalny model męskości. Z drugiej strony wypowiadali się na temat komfortowego, sportowego stylu ubierania się. Dostrzegali także proces starzenia się, pojawianie się zmarszczek czy siwizny, co wpisuje się zdecydowanie w nowoczesny model męskości, bardziej podatnej na ocenę własnego wizerunku. Podobnie jak kobiety część mężczyzn była także skłonna - niezależnie od swojego wieku - krytycznie opisywać swój wygląd. Warto zauważyć, że młodzi mężczyźni zwracali uwagę na pewne elementy wyglądu, o których mówiły kobiety (a które były pomijane przez mężczyzn z pozostałych kategorii wiekowych). Wskazywali oni często na włosy czy kolor oczu jako cechy ich wyróżniające. Najmłodsi badani najczęściej charakteryzowali się poprzez opis swojego wzrostu (najczęściej wysokiego) i sylwetki (zazwyczaj określanej jako szczupłej). Z kolei mężczyźni w średnim wieku zwracali uwagę na to, że zachowanie „męskiej sylwetki", czyli takiej, która jest umięśniona i wysportowana, nadal atrakcyjna dla płci przeciwnej - kosztuje ich dużo poświęcenia (chodzenie na siłownię, czas poświęcony na dbanie o ciało). Również warto zwrócić uwagę, że w kategorii wiekowej 38-62 lata panowie najczęściej zwracali uwagę na ubieranie się w klasyczny sposób, który wpisuje się w typowy dla patriarchalnego społeczeństwa modelu męskości. Mężczyźni w średnim wieku i ci starsi mówili także o procesie utraty silnego ciała, zaniedbywaniu się i zauważaniu symptomów starzenia, takich jak łysienie, siwienie, pojawianie się zmarszczek, worków pod oczami. Może to świadczyć o zmianach, jakie zachodzą w obszarze wizerunku współczesnych mężczyzn jako tych, którzy także powinni dbać o swój wygląd i przykładać do niego wagę.

W wypowiedziach kobiet i mężczyzn pojawiają się elementy dotyczące kanonu atrakcyjności, o których pisali C. Hakim (2010), D. Hamermesh i J. Biddle (1994), czyli posiadania szczupłej sylwetki w przypadku 
obu płci, muskulatury u mężczyzn i tak zwanych „kobiecych kształtów” w przypadku kobiet. Panie mówiły także o swojej cerze i włosach. Warto jednak zaważyć, że wśród osób w średnim i starszym wieku pojawił się także inny element $\mathrm{z}$ teorii C. Hakim, dotyczący kapitału ludzkiego, jakim jest urok i wdzięk, a także pozytywna energia oraz „bycie duszą towarzystwa" (Hakim 2010). Osoby w tym wieku często opisywały siebie przez pryzmat tego, że są uśmiechnięte i pogodne, a tym samym postrzegane jako bardziej atrakcyjne dla innych. Być może w kontekście osób $\mathrm{w}$ tych najstarszych kategoriach warto pamiętać, że kiedy zdają sobie sprawę $\mathrm{z}$ tego, że atrakcyjność $\mathrm{w}$ wymiarze fizycznym przemija, ważne jest zachowanie atrakcyjności społecznej, a ludzie uśmiechnięci są postrzegani przez otoczenie w bardziej pozytywny sposób.

Kobiety na ogół dokładniej opisują swój wygląd, wskazując na wiele istotnych detali, na które nie zawsze zwracają uwagę mężczyźni. Jednak $\mathrm{w}$ kontekście analizowanego $\mathrm{w}$ tym podrozdziale materiału, nie w pełni można zgodzić się ze stawianą hipotezą, że to kobiety częściej niż mężczyźni postrzegają wygląd jako zasób kapitału ludzkiego, mający wpływ na ich społeczne funkcjonowanie. I kobiety, i mężczyźni w swoich wypowiedziach byli skłonni krytycznie opisywać swój wygląd. W przypadku kobiet może to świadczyć o przywiązywaniu się do bardziej tradycyjnego sposobu postrzegania kobiecości, w której to kobieta podlega surowej ocenie swojego wyglądu ze względu na poszczególne atrybuty (proporcjonalna budowa, symetryczna twarz, pełne usta itd.). W przypadku mężczyzn ta zwiększona krytyka w stosunku do własnego wyglądu świadczy o przesunięciu się postrzegania męskości w bardziej nowoczesny sposób, w którym wygląd zewnętrzny odgrywa również ważną rolę. Jeśli chodzi o kategorie wiekowe, to płeć słabo różnicuje postawy wobec wyglądu młodych ludzi, którzy są świadomi tego, jak ważną rolę odgrywa on w ich życiu. Postawy osób w średnim wieku i starych wobec wyglądu są zróżnicowane ze względu na płeć, ale nie wynika to jednoznacznie z tego, że realizują wyłącznie patriarchalne wzory kobiecości i męskości. We wszystkich kategoriach wiekowych, te dwa modele - patriarchalny i nowoczesny - współistnieją i wzajemnie na siebie wpływają, co czasem przyczynia się do kontrastujących ze sobą opinii u tych samych badanych osób.

\subsubsection{Czynniki wpływające na wygląd według kobiet i mężczyzn w różnym wieku (Julita Czernecka)}

Ciało ludzkie jest kształtowane nie tylko przez uwarunkowania biologiczne, społeczno-kulturowe, ekonomiczne czy środowiskowe, ale także w toku interakcji międzyludzkich. Często to właśnie w odniesieniu do 
obserwacji ciał innych ludzi będących dla nas pewnego rodzaju lustrem, w którym się przeglądamy, dokonujemy porównania tego, jak wyglądamy w szerszym kontekście, w stosunku do innych. Szukamy podobieństw i różnic, sprawdzamy, na ile nasze ciało wpisuje się w określone kanony piękna i brzydoty, zdrowia czy jego braku, normalności lub odstępstwa od niej (Wieczorkiewicz 200o). Ten podrozdział poświęcony jest przedstawieniu czynników, które zdaniem osób biorących udział w niniejszym badaniu, wpływają na to, w jaki sposób wyglądają. Zostaną w nim opisane uwarunkowania, które są typowe dla danej płci i kategorii wiekowej, oraz te najmniej reprezentacyjne.

Kobiety i mężczyźni w różnym wieku podczas wywiadów swobodnych mówili o kilku istotnych - wspólnych dla wszystkich - okolicznościach decydujących o ich wyglądzie. Najwięcej osób wskazało na czynniki genetyczne, dziedziczone po najbliższych, szczególnie po rodzicach. W drugiej kolejności mówiono o samopoczuciu, a także aspektach osobowości, które odgrywają znaczącą rolę w kontekście wyglądu. Badani odnosili się także do kwestii ogólnego dbania o siebie, używania kosmetyków, korzystania z usług profesjonalistów, a także właściwego odżywiania się czy aktywności fizycznej. Ważnym aspektem było także dbanie o zdrowie, które było utożsamiane w tym kontekście z dbaniem o wygląd. Wszystkie kategorie badanych zwracały uwagę także na czynniki ekonomiczne, bycie osobą aktywną towarzysko i zachowanie sprawności umysłowej. Pojawiały się także nieliczne wypowiedzi nawiązujące do czynników zewnętrznych, takich jak środowisko, pogoda, klimat czy przemiany cywilizacyjne. W końcu mówiono również o roli konkretnych sytuacji życiowych i losowych, które niejako odciskają "piętno" na wyglądzie.

Mówiąc o czynnikach, które mają wpływ na aparycję człowieka, kobiety i mężczyźni biorący udział w badaniu odwoływali się w pierwszej kolejności do cech dziedziczonych po przodkach, genów, które mają podstawowe znaczenie i determinują to, jaką mamy powierzchowność:

To jak wyglądam, na pewno zależy trochę od genów [...]. Czasami nie mamy wpływu na naszą sylwetkę, to znaczy nie do końca zależy ona tylko od nas, tylko właśnie od genów (KM_13_34). Na pewno geny. Ewidentnie i tutaj, oczywiście, nie jestem genetykiem ani medykiem, ale w takim moim potocznym rozumieniu, geny, czyli jakaś konstrukcja taka niezależna od nas (KSR_5_47). To są geny, ale na to się nie ma wpływu, to jest uwarunkowane genetycznie, więc ciężko powiedzieć, że od czegoś zależy, znaczy zależy nie ode mnie, że jestem szczupły (MM_14_35). Na pewno natura, urodziliśmy się tacy, czyli to ma wpływ w dużym procencie (MSR_4_40). Przede wszystkim to jest nasze podłoże genetyczne, co w nas siedzi, determinacja rodzinna (MST_4_64). 
W tych wypowiedziach odnajdujemy odwołania do tak zwanego kapitału biologicznego, który staje się przedmiotem poddawanym refleksji (Jakubowska 2009a). W tym kontekście badani odwołują się przede wszystkim do fizycznych cech dziedziczonych, takich jak rysy twarzy, wzrost, budowa ciała, określone skłonności ciała - na przykład tycie czy zachowanie szczupłej sylwetki, łysienie czy posiadanie bujnych włosów. Zarówno kobiety, jak i mężczyźni w różnym wieku mówili o dziedziczeniu cech przede wszystkim w pierwszej linii, czyli po rodzicach. Wiele $\mathrm{z}$ tych wypowiedzi nie różnicowały ani płeć, ani wiek. Jest to bowiem taki rodzaj uwarunkowań, który nie do końca - w opinii badanych - może zostać poddany przekształceniom:

Mój wygląd zależy na pewno od rodziców, od genów, mam różne rzeczy po nich (KM_1_21). Po rodzicach pewne rzeczy dziedziczymy, więc, no to na pewno ma jakiś wpływ (MM_1_21). Fajne geny to jest podstawa i tu mogę podziękować swoim rodzicom, bo pewne rzeczy dziedziczy się i czy pracujesz, czy nie pracujesz nad sobą, czy zawodowo jesteś aktywny, to z pewnymi rzeczami nie jesteś w stanie uporać się (MSR_5_46).

Jednak warto zwrócić uwagę przede wszystkim na różnice, jakie się pojawiały $\mathrm{w}$ tym kontekście $\mathrm{w}$ wypowiedziach uczestników badania. Kobiety najczęściej porównywały się do swoich matek. Jedne podkreślały, że wygląd odziedziczyły po swoich matkach i widzą bezpośrednie podobieństwo. Inne wręcz przeciwnie - odcinały się od tego, wskazując, że być może „wrodziły się" do rodziny ojca i do matek nie są lub nie chcą być podobne. Zazwyczaj wypowiedzi te miały zabarwienie oceniające. Raz pozytywne - w przypadku kiedy respondentki cieszyły się, że odziedziczyły po matkach figurę, „brak” zmarszczek, bujne włosy czy inne - ich zdaniem atuty. Innym razem negatywne - kiedy podkreślały, że robią wszystko, by jak swoje matki nie wyglądać. Co ciekawe, młode kobiety wypowiadały się na temat dziedziczonych genów najczęściej spośród wszystkich respondentek z różnych kategorii wiekowych, ale jednocześnie najbardziej ogólnie. W przypadku kobiet w średnim wieku wypowiedzi te były obszerniejsze i prawie każda nawiązywała do kwestii dziedziczenia po swojej matce i warto zauważyć, że podkreślały swoistą „walkę z genami matki”. Jedna $\mathrm{z}$ wypowiadających się na ten temat kobiet przyznała, że sama o siebie stara się dbać, natomiast jej mama w ogóle o siebie nie dba, a mimo tego „dość dobrze” - jej zdaniem - wygląda. Wypowiadająca się na ten temat rozmówczyni starała się zwrócić uwagę na to, że „urodzie trzeba pomóc, tak jak ona to robi” i „jakby (jej mama o siebie - przyp. aut.) zadbała, to byłaby super" (KSR_2_41). Mimo wszystko podkreślała, że zazwyczaj ludzie nie dowierzają jej matce, że ma tyle lat, ile widnieje w numerze pesel, bo wygląda na młodszą niż jest 
w rzeczywistości. Jednak widocznie dało się odczuć w jej wypowiedzi negatywną ocenę dotyczącą tego braku dbania o wygląd przez matkę i podkreślaniu, że w przypadku badanej jest zupełnie inaczej, bo ona sama potrafi zadbać o „odziedziczoną urodę”. Inna kobieta wyraziła zadowolenie, że „na szczęście” do matki się „nie wrodziła”, tylko do rodziny ojca, i z tego powodu się cieszy, bo nie musi walczyć z otyłością:

Mama niestety ma lekką nadwagę, próbowała kilka razy diet, ale jakoś jej się nie udawało. Teraz wiem, że to geny i ona nigdy nie będzie jakoś bardzo szczupła. Ja natomiast jakby za wszelką cenę chcę utrzymać figurę i mam nadzieję, że mi się to uda. Może jestem bardziej do rodziny ojca podobna, oni są szczuplejsi niż rodzina mojej mamy, więc to jakby geny też tu wchodzą w rachubę (KSR_4_45).

Jednak badana ta nie była pewna, czy to geny decydują o tym, że zachowuje szczupłą sylwetkę, czy nieustanna walka o jej zachowanie. Była także wypowiedź kobiety $\mathrm{w}$ średnim wieku, która $\mathrm{w}$ ogóle nie utożsamiała się z wyglądem swojej matki i w bardzo kategoryczny sposób się od niego odcinała: „To chyba geny, ja nie mam pojęcia. Moja mama to w ogóle jest anty-ja. W ogóle nie jestem do niej podobna, nie utożsamiam się z nią i za wszelką cenę nie chciałabym być do niej podobna" (KSR_3_42).

Z kolei w wypowiedziach starszych kobiet pojawił się pozytywniejszy stosunek do dziedziczonych przez nie cech wyglądu po matkach. Oto jedna $\mathrm{z}$ takich wypowiedzi:

Ja myślę, że po mojej mamie (odziedziczyłam wygląd - przyp. aut..), bo ona nie miała zmarszczek, miała 84 lata kiedy zmarła i nie miała w ogóle zmarszczek. Jak widzisz, ja nie mam też specjalnie zmarszczek. W tym wieku, w którym one się tam tworzą, w tym wieku to się powinno więcej mieć, a jednak tego nie ma tylu, bardziej taka czerstwa jest skóra (KST_14_86).

Inna kobieta zwróciła uwagę na to, że nie tylko odziedziczyła młody wygląd po mamie, ale także to, że należy dbać o swój wygląd: „Pewno geny, moja mama też nie wygląda na swoje lata, jest osobą zadbaną bardzo, nie wkłada w swoją urodę dużo zabiegów, a wygląda bardzo młodo i jej nikt nie mówi, że ma te lata, na które powinna wyglądać, zawsze jest zadbana, włosy ma zrobione, tak samo ja, ja nie wyjdę na ulicę jak nie jestem podmalowana troszeczkę" (KST_2_64).

Starsze kobiety niejednokrotnie zwracały uwagę także na to, że sam proces starzenia się i jego wpływ na wygląd jest często zależy od czynników genetycznych. Nawiązywały przede wszystkim do sytuacji, kiedy geny decydują o tym, czy ktoś wygląda na dużo młodszego czy starszego mimo swojego wieku: „Na pewno są też cechy genetyczne, które decydują 
o tym, że ktoś dłużej zachowuje młody wygląd, a ktoś szybciej dostaje zmarszczki (KST_8_70). Cechy genetyczne też wpływają dużo na cerę i na wygląd, bo jak ktoś nie ma tych cech, no to nawet mając te lat trzydzieści, to będzie wyglądać jak pięćdziesiąt" (KST_11_77). Warto zauważyć, że to silne odniesienie do podobieństwa $\mathrm{z}$ matkami lub jego braku w przypadku kobiet nie dotyczy tylko uwarunkowań genetycznych, ale także określonych zachowań wobec wyglądu. Być może w toku obserwacji tego, jak matki traktują swój wygląd, uczestniczki badania albo zinternalizowały podobne zachowania $\mathrm{w}$ toku socjalizacji, albo nie chciały ich naśladować. $W$ tym drugim przypadku być może silniejsza identyfikacja nastąpiła z przedstawicielkami rodziny ojca lub niego samego. Można nawiązać tu do teorii uczenia się ról, w której to bardzo ważna staje się identyfikacja zachowania i naśladowania rodziców. Nie zawsze dziecko naśladuje tylko rodzica własnej płci, ale też odmiennej, i wybiera ten model, który jest mu bliższy (Tillman 1996).

Młode kobiety w bardzo ogólny sposób wypowiadały się na temat dziedziczonych cech. Być może jest to spowodowane właśnie ich młodością i atrakcyjnością, co za tym idzie, mniejszą refleksyjnością nad tym jakie „pozytywne” czy „negatywne” cechy odziedziczyły po swoich rodzicach, a szczególnie po matkach. W przypadku kobiet w średnim wieku wypowiedzi negatywnie oceniające wygląd ich matek były wygłaszane głównie przez czterdziestolatki oraz pięćdziesięciolatki. Czterdzieści lat to często wiek określany mianem „przejściowego” między młodością, a wiekiem dojrzałym. Być może to wtedy kobiety mierzą się z „utratą młodości”, i brakiem pewnego „oswojenia się" czy utożsamienia $\mathrm{z}$ wiekiem średnim. To czas, w którym kobiety starają się nadal zachować młodzieńczy wygląd i szczupłą sylwetkę - promowaną tak szeroko przez współczesną kulturę - a jest to niekiedy trudne ze względu na uwarunkowania genetyczne i związane z biologicznym cyklem życia (starzenie się skóry, wchodzenie w menopauzę). Te badane, które się nie identyfikują z wyglądem swoich matek, pragną realizować własną koncepcję wyglądu. Z kolei najstarsze respondentki są w pewnym sensie „wdzięczne” matkom „za dobre geny”, które pozwalają im opóźnić oznaki starzenia się i zachować młodszy - niż to wskazuje metryka - wygląd. Sam wiek także nie pozostaje w tym przypadku bez znaczenia. Kobiety w procesie widocznego starzenia się są bardziej świadome wpływu upływającego czasu na ich wygląd i być może dlatego w tej kategorii wiekowej bardziej doceniają "dobre geny” odziedziczone po matkach niż młodsze respondentki.

Mężczyźni byli także świadomi, że ich wygląd w dużej mierze zależy od tego, jakie geny odziedziczyli po przodkach. I zdają sobie także sprawę z tego, że nie zawsze mogą wpłynąć na wygląd sylwetki, proces starzenia się czy łysienia: 
Na pewno jakieś tam czynniki genetyczne też mają wpływ na to, w jaki sposób się ludzie starzeją, jeżeli ktoś ma predyspozycje do tego, że z zewnątrz wygląda dojrzale, chociaż jest młody, to też ciężko pewnie mu z tym jakoś walczyć. Chociażby w przypadku mężczyzn szybsza tendencja do tracenia włosów na głowie, tak? [...], a jest to jakaś tam cecha dziedziczna w większości przypadków (MM_7_28). W 90\% jednak determinanty rozwojowe, biologia, zwłaszcza jeśli chodzi o twarz [...], głównie determinanty biologiczne (MSR_3_40).

Według jednego z nich dzięki „fajne geny, to jest podstawa” i jest wdzięczny rodzicom za nie, ponieważ „pewne rzeczy dziedziczy się i czy pracujesz, czy nie pracujesz nad sobą, czy zawodowo jesteś aktywny, to z pewnymi rzeczami nie jesteś w stanie uporać się” (MSR_5_46).

Młodsi mężczyźni upatrywali podobieństwa genetycznego zarówno do swoich ojców, jak i matek. Niektórzy twierdzili, że w połowie geny odziedziczyli po jednym i drugim rodzicu: „Oczy mam po mamie [...], chyba po ojcu odziedziczyłem kruchość włosów” (MM_8_29), „Genetycznie, jeśli chodzi o budowę ciała, to na pewno do ojca jestem podobny, z wyglądu to mama” (MM_11_31). Tylko jeden młody mężczyzna porównał swoją sylwetkę do braci, podkreślając genetyczną odmienność od nich, ponieważ „oni byli chudzi jak szczypiorki”, a on w stosunku do nich był „gruby” (MM_5_25). Mężczyźni w średnim wieku i starsi częściej w wypowiedziach mówili o swoich przodków z linii męskiej - szczególnie porównywali się do swoich ojców, czasem dziadków. Nie pojawiały się jednak porównania czy odniesienia do matek. Panowie w średnim wieku, mówiąc o podobieństwie do ojców, nawiązywali głównie do dwóch aspektów - łysienia i wzrostu. Jeden z respondentów przyznał, że po ojcu odziedziczył niski wzrost. Być może zwrócił na to szczególną uwagę, bo w tradycyjnym modelu męskości wzrost odgrywa duże znaczenie. Gdy ktoś jest obdarzony wysokim wzrostem. jednocześnie jest odbierany jako osoba z większym autorytetem (por. Skrok 2009, Gladwell 2008). Mężczyźni zwracali uwagę także na dziedziczenie tak zwanego „wysokiego czoła”. Warto zwrócić uwagę na to, że im mężczyźni byli starsi, tym także podkreślali to, że stają się podobni do swoich ojców. Jeden $\mathrm{z}$ nich podkreślił, że dzięki genom ojca ma w wieku 70 lat jeszcze włosy (MST_8_70). Inny stwierdził, że wraz z upływem czasu stał się niejako odzwierciedleniem wyglądu swojego ojca: „Ja wiem, geny, geny [...], jak byłem młody, to nie byłem podobny do ojca, ale dzisiaj to można powiedzieć, że lustrem mogę (być - przyp. aut.)" (MST_3_63). Młodzi mężczyźni choć najliczniej wskazywali na kwestię dziedziczenia genów, mieli także dość pobieżne refleksje na ten temat. Im respondenci byli starsi, tym częściej zauważali podobieństwa do ojców czy dziadków, podkreślając posiadanie pozytywnych "genów”: wysoki wzrost, posiadanie włosów 
na głowie czy wolniejsze starzenie się, lub tych negatywnych: utraty włosów, pojawienia się zakoli, niskiego wzrostu. Być może, tak jak w przypadku kobiet, doceniane są przede wszystkim te "geny”, które gwarantują pozostanie dłużej atrakcyjnym. $\mathrm{Z}$ analizy powyższych wypowiedzi wynika, że wygląd dla współczesnych mężczyzn ma coraz większe znaczenie, bo zwracają uwagę szczególnie na te elementy, które decydują, że we współczesnej kulturze danego mężczyznę uznajemy za atrakcyjnego bądź nie.

Podsumowując ten fragment analizy wyników badań, należy zwrócić uwagę, że młode kobiety i młodzi mężczyźni byli najliczniejszą grupą, która upatrywała uwarunkowań swojego wyglądu w cechach dziedziczonych przez rodziców. Częściej niż inne kategorie wiekowe zwracali oni uwagę na podobieństwo do rodziców, zarówno ojca, jak i matki (niezależnie od płci respondenta), szczególnie w kontekście sylwetki i dziedziczonej skłonności do szybszego lub wolniejszego starzenia się (panowie dodatkowo na procesy łysienia). Jednak wypowiedzi młodych ludzi były mało rozbudowane, co może świadczyć o ich poczuciu atrakcyjności, młodości i dostrzeganiu podobieństwa fizycznego tylko na poziomie dość płytkiej refleksji. Inna sytuacja dotyczy osób w wieku średnim, którzy potwierdzają lub zaprzeczają podobieństwu z rodzicem swojej płci. W wypowiedziach tej kategorii wiekowej nawiązywano ogólnie do procesu starzenia się i przede wszystkim kształtu sylwetki. Pojawia się tu także większa świadomość determinantów biologicznych i ich wpływu na zachowanie młodego i atrakcyjnego wyglądu lub wręcz przeciwnie - szybszej jego utraty. Kobiety często podkreślały, że obecnie muszą „walczyć z genami” matek, których nie akceptują. Także mężczyźni częściej wspominali o mankamentach wyglądu, które odziedziczyli po męskiej linii przodków. Być może wraz z upływającym czasem osoby w tej kategorii wiekowej częściej i bardziej „naocznie” konfrontują się ze zmianami, które zachodzą $\mathrm{w}$ ich ciele i ich nie akceptują - nie uznając też utraty samej młodości. Cechy wrodzone stają się bardziej widoczne niż u młodych ludzi. U starych ludzi z kolei następuje wyraźny zwrot ku wskazywaniu tych cech dziedziczonych po bliskich, które są pozytywne - brak zmarszczek i zachowanie młodzieńczego wyglądu, zachowanie włosów (w przypadku mężczyzn). To stawanie się odbiciem lustrzanym wyglądu rodziców - ojców w przypadku mężczyzn, a matek w przypadku kobiet - przybiera formę wyrażenia aprobaty i zadowolenia z faktu, że tak właśnie w ich przypadku się stało.

Kolejnym ważnym aspektem, który wpływał zdaniem badanych osób na ich wygląd, było samopoczucie. Najczęściej mówili o wpływie określonych sytuacji życiowych na pojawiające się emocje i nastroje, a także o roli stresu. Istotne było także własne podejście do życia, pozytywne 
bądź negatywne, i to, w jaki sposób oni sami ten stosunek do własnej egzystencji tworzą. Nie bez znaczenia okazała się także społeczna aktywność, towarzyskość i kontakty z innymi. Badani z wszystkich kategorii wiekowych wypowiedzieli się na temat samopoczucia, jednak od razu warto zaznaczyć, że wypowiedzi kobiet $\mathrm{w}$ tym zakresie były dominujące. Oto kilka ogólnych cytatów z przeprowadzanych wywiadów: „Samopoczucie [...], to jak się czujemy, wpływa na to jak wyglądamy i jak postrzegają nas inni” (KM_3_24). „Wygląd zależy od chyba charakteru, [...] od podejścia do życia” (KST_11_77). „Samopoczucie przekłada się na wygląd (MM_6_27). Od czego to zależy jak ja wyglądam, od tego jak się czuję chyba, tak wyglądam" (MST_8_70). Istotne były jednak różnice w kontekście wypowiedzi między poszczególnymi kategoriami badanych.

Kobiety zazwyczaj odwoływały się do swojego nastroju, który ich zdaniem miał największy wpływ na to, czy w danym momencie wyglądają dobrze, atrakcyjnie czy wręcz przeciwnie. Dostrzeżono, że zmęczenie, zniechęcenie i spadek "humoru” negatywnie wpływa na to, jak się one prezentują na zewnątrz. Co ciekawe, najmłodsze wypowiadające się na ten temat kobiety podkreślały znaczenie pewnej labilności emocjonalnej, która ich zdaniem nie do końca zależy od nich samych, a od czynników zewnętrznych. Inaczej obrazują to wypowiedzi kobiet w średnim wieku i starszych, które uważają, że same także mają wpływ na nastrój i samopoczucie, a tym samym na swój wygląd.

Młode kobiety wiążą to jak się prezentują z samopoczuciem, powołując się na różne czynniki natury losowej, takie jak problemy w życiu prywatnym czy w pracy zawodowej. Ich daniem wpływają one na stan psychiki, a co za tym idzie, odzwierciedlają się w ich wyglądzie:

To jak się czuję psychicznie, to bardzo, bardzo dużo potrafi zmienić. Czasami po prostu patrzę w lustro, źle się czuję i powiedzmy jestem niewyspana albo mam ciężkie momenty czy w pracy, czy w życiu osobistym, i patrzę na siebie, i widzę po prostu cień człowieka, podkrążone oczy, szarą cerę [...]. I dużo, dużo właśnie zależy od tego jak się czuję. Jak się czuję psychicznie, albo czasami sobie stanę przed lustrem »E, fajna laska ze mnie jest!«, i wtedy mogę iść do pracy i gdziekolwiek, i się dobrze czuję, mimo że wyglądam tak samo jak dzień wcześniej! Psychika dużo robi (KM_8_29). Myślę, że [...] sytuacja życiowa (ma wpływ na wygląd - przyp. aut.), bo to jednak w danym momencie jestem zadowolona ze swojej sytuacji życiowej, bo to na pewno jakieś przygnębienie czy problemy dodają lat, czuję się jakaś taka, dojrzalsza, poważniejsza, starsza, zmęczona bardziej, to wpływa na pewno (KM_15_36).

Warto zwrócić uwagę, że najmłodsze uczestniczki badania, mówiąc o swoim wizerunku widzianym w lustrze, bardzo szczegółowo go opisują, zwracając uwagę na najdrobniejsze szczegóły, takie jak wyraz oczu, 
sposób układania się włosów, stan skóry, która jest „świeża” lub „zmęczona". Czasem dość radykalne same siebie oceniają - jednego dnia wyglądają „fenomenalnie”, drugiego już „fatalnie”. Tak jak to opisała jedna z nich: „Jednego dnia staję przed lusterkiem i stwierdzam, że z niczego nie jestem zadowolona, a innego dnia oczy się błyszczą i zupełnie się inaczej wygląda [...], to zależy od dnia, nieraz siebie lubię i już, a nieraz nie podoba mi się nic" (KM_10_30). Z drugiej strony młode kobiety uważają, że złe samopoczucie lub zmęczenie zniechęca do podejmowania jakichkolwiek działań na rzecz ulepszenia własnego wizerunku. Nie widzą wtedy sensu w dobieraniu atrakcyjnego wizualnie stroju, robieniu makijażu czy fryzury. Przyznają, że kiedy mają zły nastrój, nie ma też „siły” o siebie zadbać. Jedna $\mathrm{z}$ nich skomentowała to $\mathrm{w}$ ten sposób, że jeśli ma "gorszy dzień", to bardzo długo zajmuje jej zrobienie sobie makijażu, a i tak się wtedy sobie nie podoba, choć „niby ładnie wygląda” (KM_5_28). Kiedy towarzyszy im obniżenie nastroju, młode kobiety przyznają, że ma to wpływ nie tylko na makijaż, czy fryzurę, ale także na sposób, w jaki się ubierają: „Jeżeli mam więcej czasu i chęci, to staram się wyglądać ładniej, czyli nowe modne ciuchy, buty, fryzura i mocniejszy makijaż. Natomiast, gdy mam zły dzień, jestem niewyspana albo po prostu mi się nie chce, to lekki makijaż i luźne, wygodne ciuchy" (KM_13_34).

$\mathrm{W}$ wypowiedziach kobiet $\mathrm{w}$ średnim wieku można było wychwycić zdecydowanie większy (niż miało to miejsce w przypadku młodych kobiet) wpływ ich samych na samopoczucie i tym samym na ich wygląd. Mówiły o większej sprawczości i aktywnych działaniach, które podejmują $\mathrm{w}$ tych obszarach. Kilka respondentek wyjaśniało to w swoich wypowiedziach w następujący sposób:

Przede wszystkim ode mnie samej, zawsze się staram żebym ja ze sobą się czuła dobrze (KSR_9_54). Jest ode mnie zależne, niezależnych to prawie nie ma (czynników wpływających na wygląd - przyp. aut.), zależne ode mnie to jest to, czy ja będę dbała o siebie czy nie, czy będę bardziej wypoczęta czy nie będę, czy pójdę do fryzjera obciąć włosy czy nie, bo nie muszę chodzić systematycznie, ale obciąć włosy do tego fryzjera muszę, bo się wtedy dobrze czuję i koniec (KSR_12_60).

Ten wpływ na samopoczucie odbywa się także poprzez dobór odpowiedniego stroju. Wybierają te ubrania, w których dobrze się czują: „Jeżeli mam dobre samopoczucie, jeżeli dobrze się czuję w jakimś ubiorze, to potrafię go nosić, potrafię go prezentować i uważam, że ubiór powinien być szalenie dostosowany do psychiki, nie można nosić wszystkiego" (KST_4_66). Jedna z nich wprost przyznała, że jeśli za oknem jest zimo i jest brzydka pogoda, ona sama musi dodać sobie energii poprzez odpowiednie dobranie kolorystyki ubrania i założenie „żarówiastego 
stróju", nie przejmując się opiniami innych (KSR_9_54). Tylko jedna kobieta $\mathrm{w}$ grupie $\mathrm{w}$ średnim wieku przyznała, że „jak ma jakąś wścieklicę w środku” to się ubiera „dziwnie, bez składu, bez ładu” (KSR_8_53). W grupie najstarszych badanych także pojawiła się warta uwagi wypowiedź dotycząca tego, że ubiór zawsze powinien być dostosowany do naszego samopoczucia. Zdaniem jednej z nich nawet najmodniejsze rzeczy nie będą do nas pasować i nie będą mogły być dobrze prezentowane, jeśli nie będą odzwierciedlać stanu naszej „psychiki”. Z kolei te ubrania, które będą odpowiadać, współgrać z nastrojem, powodują, że ci, którzy je noszą będą się w nich dobrze czuć (KST_4_66).

Reasumując wypowiedzi kobiet biorących udział w badaniu, należy zauważyć, że ich zdaniem pozytywne podejście do życia i optymizm mają istotne znaczenie wpływające na wygląd zewnętrzny. Część z nich, niezależnie od wieku, była świadoma wpływu cech osobowościowych na ogólne nastawienie do życia. Ich zdaniem optymizm życiowy dodatnio oddziałuje także na to, jak się prezentują w oczach innych ludzi i w jaki sposób są odbierane społecznie. Młode kobiety, podając przykłady takich sytuacji, nawiązywały raczej do negatywnych konsekwencji braku optymizmu życiowego: „Nieraz widzę takie laski, które są piękne, jakbyś spojrzała, to dałabyś je na okładkę Vogue, a stoi taka $z$ wykrzywioną buzią i pomimo, że wygląda jak milion dolarów, to nie miałabym $\mathrm{z}$ nią ochoty porozmawiać, bo jakoś odstrasza, mimo, że jest śliczna” (KM_5_28). Inna młoda respondentka także zauważyła, że brak pozytywnego nastawienia do życia, przekłada się na postrzeganie wyglądu jako nieatrakcyjnego, zmniejsza szanse na kontakty z innymi ludźmi, którzy ignorują tych, którzy mają „zły humor” (KM_3_24). Podobną wypowiedź odnajdziemy wśród kobiet starszych: „Usposobienie takie wewnętrzne też ma znaczenie, jak ktoś jest stale przygnębiony, to też wpływa na wygląd zewnętrzny" (KST_16_89). Zachowanie dobrego samopoczucia i optymizmu z kolei pozytywnie wpływa na zachowanie dobrych relacji międzyludzkich i znaczącą aktywność towarzyską (KST_6_69). Dało się zauważyć także takie wypowiedzi, które mówiły o tym, że optymistyczna postawa życiowa powoduje, że inni ludzie postrzegają nas jako młodszych niż w rzeczywistości jesteśmy: „Gdy jest się optymistycznym, uśmiecha się, jest się wesołym, przyjemnym, miłym i tak dalej, to się jest postrzeganym takim młodszym, czy nawet jest się takim młodszym nie jest, tak?” (KSR_5_47). To również nawiązanie do takich elementów kapitału erotycznego kobiet, jakim są urok, wdzięk, bycie miłym i uśmiechniętym. C. Hakim zwracała uwagę na to, że te aspekty są częściej przez kobiety wykorzystywane w relacjach międzyludzkich (Hakim 2010). Być może tak częste odwoływanie się przez 
kobiety do samopoczucia i nastroju jako czynników w tak ważnym stopniu wpływających na ich wygląd można wytłumaczyć tym, że psychiczne życie kobiet jest bardziej związane $\mathrm{z}$ ciałem niż życie mężczyzn, ponieważ kobiety posiadają specyficzną skłonność do ozdabiania swojego ciała niezależnie od kultury i czasów, w których żyją. Według J. Ortegi y Gasseta fizjologia kobiet narzuca im nawyk nieustannego czuwania nad swoim ciałem, które tym samym staje się - $\mathrm{w}$ ich perspektywie patrzenia na świat - najbliższym obiektem. Dlatego ciało i dusza kobiet są ze sobą nierozerwalnie połączone (Ortega y Gasset 1982).

Mężczyźni dużo rzadziej niż kobiety wspominali o znaczeniu samopoczucia w kontekście wyglądu. Nie powoływali się także na samo słowo „nastrój”, tak wielokrotnie przywoływane przez uczestniczki badania. Jeśli już wskazywali na ten czynnik, to raczej w odniesieniu do wpływu stresu i problemów życiowych na wygląd. Były też aspekty wspólne z tymi poruszanymi przez panie - mówiono o kontaktach towarzyskich oraz pozytywnej bądź negatywnej postawie życiowej.

Najmłodsi mężczyźni biorący udział w badaniu zdecydowanie najczęściej wskazywali na powiązanie czynników psychologicznych z wyglądem. Mówili szczególnie o problemach życiowych i emocjach, jakie im towarzyszą, które w znaczący sposób „odbijają się” na tym, jak się prezentują:

Od samopoczucia trochę zależy wygląd, postawą ciała na pewno wyraża (człowiek - przyp. aut.) swoją dyspozycję psychiczną, jak jest przybity, to się garbi, jak się czuję świetnie, to ma otwartą klatkę piersiową (MM_6_27). Właściwie wszystko wpływa na to, jak wyglądamy. To, czy jesteśmy wypoczęci, czy nasz aktualny stan, że tak powiem, zdrowia psychicznego jest optymalny, czy też mamy jakieś troski (MM_7_28).

Młodzi badani mówili także o negatywnym znaczeniu stresu, który może przyczyniać się do powstawania różnych chorób, a także popadania $w$ stany depresyjne. Jeden $z$ wypowiadających się na ten temat mężczyzn przyznał, że w dzisiejszych czasach jednym z głównych czynników stresotwórczych jest brak pewności zatrudnienia, a jego zdaniem stała praca i zapewnione dochody wypływają na poziom zadowolenia z życia i poczucie szczęścia. Jego zdaniem, kiedy jesteśmy usatysfakcjonowani swoją sytuacją życiową, to mamy także motywację do dalszego działania zmierzającego do podnoszenia własnej atrakcyjności, dbania o swój wygląd (MM_10_31). W innej wypowiedzi reprezentanta najmłodszej kategorii mężczyzn pojawia się odwołanie do określonych cech charakteru, takich jak pewność siebie, która sprawia, że człowiek nie tylko wygląda lepiej, ale pewny swoich atutów, ma większy wpływ na innych i łatwiej mu przychodzi osiąganie tego, co sobie w życiu zaplanował (MM_8_29). 
Jeśli chodzi o mężczyzn w średnim wieku, to warto zwrócić uwagę tylko na wypowiedź jednego z mężczyzn, który podkreślił wpływ ludzi, jakimi się otaczamy, na nasze samopoczucie. Mimo że ukończył 54 lata, to nadal ma "power”, czuje moc i zachowuje dobrostan psychiczny, właśnie dzięki otaczaniu się „fajnymi znajomymi”, którzy nie są „,zgryźliwi”, nie są malkontentami wiecznie na coś narzekającymi, tylko lubią się bawić, tańczyć i śmiać. W jego przypadku to ważne, by zachować dobre samopoczucie, bo ma obciążającą zarówno psychicznie, jak i fizycznie pracę zawodową (pracuje jako rehabilitant ciężko chorych osób) i żeby zachować optymizm, musi w jakiś sposób „odreagowywać” (MSR_9_54). Nieliczni starzy mężczyźni wspominali, że na wygląd ma wpływ przede wszystkim ogólne podejście i nastawienie do życia: „Dlaczego wyglądamy, tak jak wyglądamy? Otóż na to się składa całe nasze życie, bo to nie jest tak, że ostatnie trzy lata, tylko to jest pewien sposób bycia, sposób na życie" (MST_4_64). Inny mężczyzna w tej samej kategorii wiekowej wspominał, że jeśli człowiek ma pozytywne nastawienie do samego siebie, to jest „piękniejszy” (MST_3_65).

Analizując świadomość badanych na temat wpływu samopoczucia na wygląd, warto zauważyć, że najmłodsi respondenci i respondentki częściej interpretowali je w kontekście czynników niezależnych od nich samych, takich jak problemy życiowe, problemy z pracą etc. Może to być spowodowane $\mathrm{w}$ ich przypadku funkcjonowaniem $\mathrm{w}$ określonym cyklu życia, bowiem młodość zazwyczaj jest obarczona wieloma wewnętrznymi rozterkami i borykaniem się z nowymi wyzwaniami, jakie przed nimi stawia faza adolescencji. $Z$ kolei respondentki w średnim wieku znacząco podkreślały to, że one same mają wpływ na swój wygląd poprzez działania, jakie podejmują na rzecz utrzymania dobrego samopoczucia. Starsze osoby - i kobiety, i mężczyźni - uważali, że największy wpływ na wygląd ma zachowanie pozytywnego nastawiania do życia, w tym utrzymywanie kontaktów towarzyskich. Jest to swoiste łamanie stereotypu na temat starości, która jest zwykle postrzegana jako obarczona samotnością i niedołężnością (Tokarz 2005).

Uczestnicy badania wskazywali także inne aspekty, które ich zdaniem odgrywają istotą rolę w kontekście wyglądu. Zarówno kobiety, jak i mężczyźni zwrócili uwagę na kwestię dbania o siebie. Kobiety najczęściej mówiły o zabiegach kosmetycznych, a mężczyźni o utrzymaniu ogólnej higieny. Uczestniczki badania - niezależnie od wieku - opowiadały, w jaki sposób stosują określone kosmetyki, takie jak kremy, balsamy, a także jakim zabiegom pielęgnacyjnym poddają swoją skórę, zarówno $\mathrm{w}$ domu, jak i w profesjonalnych salonach urody. Mówiły o stosowaniu makijażu i pielęgnacji włosów (myciu, farbowaniu i układaniu). Oto kilka ilustrujących ten temat wypowiedzi: 
Mój wygląd zależy od tego na ile o siebie dbam [...], to znaczy, czy danego dnia chce mi się umalować, czy mi się nie chce, czy mi się chce założyć soczewki, czy mi się chce założyć okulary, czy mi się chce umyć głowę i mam rozpuszczone włosy, czy mi się nie chce i wtedy je zwiążę w kitkę (KM_4_27). Na pewno to dbałość o własny wygląd, to znaczy dbanie o włosy, jeżeli ktoś ma krótkie, to chodzenie do fryzjera czy układanie tych włosów, stosowanie kremów odpowiednich do własnej cery (KSR_6_48). Na wygląd wpływam ja, ponieważ dbam o swoją fizjonomię, kremuję się, ogólnie to te wszystkie odżywki, kosmetyki po prostu, kremy do twarzy, a nogi i rączki też sobie smaruję i dbam o ręce i robię sobie sama manicure, nie chodzę do manikiurzystki (KST_13_85).

Generalnie nie było w tym obszarze różnic między poszczególnymi kategoriami wiekowymi kobiet. Można powiedzieć, że te najmłodsze więcej uwagi skupiały na ilości czasu, jaki muszą zainwestować, by dobrze wyglądać i same o siebie zadbać. Z kolei kobiety w średnim wieku najczęściej mówiły o zabiegach fryzjerskich i dbaniu o ułożenie fryzury. Natomiast najstarsze badane wskazywały na używanie kremów, tak „by skóra się nie marszczyła” i wyglądała młodziej. Część z nich była świadoma zależności, jaką ma stosunek ilości czasu oraz uwagi poświęconej na pielęgnację ciała, a tym, w jaki sposób będą wyglądały i jak to wpłynie na ich społeczny odbiór.

Z kolei mężczyźni (niezależnie od wieku), mówiąc o ogólnym zadbaniu, najczęściej mieli na myśli sprawy związane z higieną ciała, czyli na przykład z byciem ogolonym, ostrzyżonym, z posiadaniem czystych paznokci. Oto wybrane wypowiedzi na ten temat:

Mówię tutaj o [...] dbaniu w sensie, ktoś jest ogolony - nieogolony, uczesany - nieuczesany, zadbaną ma fryzurę - niezadbaną, obcięte paznokcie - brudne paznokcie, zęby czarne - zęby umyte. To tak jakby codzienna, zwykła higiena stwarza nasz obraz (MSR_4_40). To ode mnie zależy, czy pójdę rano do pracy ogolony, czy nie, czy założę na przykład brudne spodnie czy czyste, czy wyprasowaną koszulę, czy niewyprasowaną [...], ja się będę jednak upierał, że wygląd od nas zależy (MST_5_54).

Dbanie o siebie nie ma mieć formy - zdaniem niektórych mężczyzn - „przesadnego narcyzmu”, czyli skupiania swojej uwagi tylko na wyglądzie. Przykładanie większego znaczenia do wizerunku najczęściej jest związane z charakterem wykonywanego przez mężczyzn zawodu. Oczywiście współcześni mężczyźni także coraz częściej stosują kosmetyki i korzystają z salonów urody, jednak jak na razie takie zachowania nie mają jeszcze charakteru masowego i odnoszą się przede wszystkim do młodych mężczyzn i tych w średnim wieku (Czernecka 2011). Warto zauważyć, że młodzi mężczyźni wśród czynników od nich niezależnych, a które 
mogą oddziaływać na wygląd zewnętrzny, wymieniali także porę roku oraz panujący klimat:

Gdy temperatury są niższe, rzadziej się golę i chodzę do fryzjera, natomiast gdy jest ciepło, staram się utrzymać niewielki zarost i krótkie włosy. Latem jest gorąco i noszenie dłuższych włosów nie jest komfortowe, jest w nich bardziej gorąco, mocniej się pocę i przez to wymagają dodatkowego mycia. To raczej ja mam wpływ na swój wygląd (MM_3_22). Lubię być delikatnie opalonym, niestety się mocno opalam, ale opalenizna też jest ważna, jeśli ktoś jest bardzo, bardzo blady, wolę bardziej opalone osoby (MM_15_37).

Zarówno w przypadku kobiet, jak i mężczyzn, upiększanie ciała za pomocą kosmetyków czy profesjonalnych zabiegów wydaje się być przez nich traktowane jako przejaw dokonywania określonego wyboru. Wyboru, dzięki któremu ciało staje się przekaźnikiem, symbolem, który poddawany jest interpretacji przez innych. Część respondentów traktuje ciało jako pewnego rodzaju zewnętrzną konstrukcję, która ma znaczenie nie tylko dla nich samych, ich samopoczucia, ale także wpływa na to, jak są postrzegani przez innych (Zawadzka 200o).

Kolejnym czynnikiem mającym wpływ na wygląd zewnętrzy, o którym wspominali uczestnicy badania, jest strój. Poruszano głównie kwestie odpowiedniego dostosowania ubrania do okoliczności, pór roku czy trendów mody, a także indywidualnego stylu ubierania się. Młode kobiety zwracały uwagę przede wszystkim na rolę stroju w tak zwanym „ukrywaniu” mankamentów sylwetki, tuszowaniu niedoskonałości figury. Kobiety $\mathrm{w}$ średnim wieku zwracały głównie uwagę na dostosowanie stroju do okoliczności i ludzi, z którymi się spotykamy:

Na pewno biorę poprawkę na to, gdzie się wybieram i z kim się spotykam. Jeżeli jest to spotkanie w plenerze, to nie pójdę $\mathrm{w}$ kilogramach biżuterii i na szpilkach. Kiedy biegnę na jakiś egzamin, mam szpile, wszystko jest ładnie, ale w torbie mam już czy sztyblety czy jakieś płaskie buty, to ja za chwile to zmieniam, bo gdzieś w innej części miasta mam spotkanie, czy coś, to ja sobie zdejmę biżuterię, jestem przetransponowana w sekundzie i biegnę dalej (KSR_9_54).

Inna wyraziła żal, że nie do końca może wybrać takie ubrania, jakie jej się podobają i są zgodne z trendami mody, bo ze względu na znaczącą otyłość musi ubierać się w to, co jest po prostu dostępne na rynku odzieżowym (KRS_8_53). Starsze badane zwracały uwagę bezpośrednio na kwestię mody i tego, $w$ jakim środowisku się obracają i jaki ma to wpływ na ich osobiste wybory. Jedna $\mathrm{z}$ nich interesuje się modą, ogląda pokazy mody i magazyny temu tematowi poświęcone, obserwuje to, w jaki sposób ubierają się znani ludzie i to wpływa na to, jakie stroje 
wybiera. Przyznaje jednak, że należy być w sprawie wyglądu krytycznym, bo nie wszystko „da się przetransponować na naszą sylwetkę”, bo nie wszystko dobrze na niej leży (KST_4_66). Inna starsza kobieta pracująca wśród młodych ludzi stwierdziła, że wiek współpracowników wpływa na to, że sama chce się ubierać atrakcyjnie i wyglądać dzięki temu na młodszą (KST_5_67).

Z kolei mężczyźni, szczególnie ci młodsi i w średnim wieku, największą wagę przypisywali właśnie okolicznościom, do których muszą dopasować swój wygląd. Ich zdaniem powierzchowność człowieka determinuje określona sytuacja życiowa, w jakiej człowiek się znajduje, a także miejsce, do jakiego się udaje, $w$ tym również środowisko zawodowe: „Wygląd zależy od pracy, od pozycji w firmie. Wiesz, jak trzy czwarte życia spędzasz w pracy, która wymaga od ciebie jakiegoś takiego wizerunku na pokaz, że tak powiem, no to przypuszczam, że jak przychodzi weekend, to nic się nie zmieni, to nie będzie tak, że całe życie będziesz się ubierać w garniaki, a sobota, niedziela będziesz się zapuszczał" (MM_13_32). Panowie mówili także ogólnie o tym, że należy wyglądać schludnie. Inni wspominali o akcesoriach, takich jak krawat czy okulary, które „podkreślają" ich osobowość. Niektórzy mężczyźni w średnim wieku uważali, że styl ubierania musi odzwierciedlać ich upodobania, oraz to, że w danym stroju muszą czuć się nie tylko komfortowo, ale przede wszystkim muszą "pozostać sobą”. Jeden z nich zauważył, że nie można jednak przekraczać „pewnych granic” - miał on na myśli, że jako osoba w określonym wieku, nie może ubierać się jak „playboy”, nawet jeśli ma się na to ochotę (MSR_6_47).

Z pewnością uczestnicy badania zdawali sobie sprawę z roli, jaką strój odgrywa w kreowaniu ich wizerunku, ale z pewnością zauważali także, że nie tylko należy go dopasować do okoliczności, ale przede wszystkim powinien odzwierciedlać „ich wnętrze” - psychikę, samopoczucie. Ten wizualny sposób wyrażania własnej indywidualności poprzez określony wygląd, symboli widocznych dla otoczenia staje się także podstawą budowania podmiotowości zarówno w przypadku kobiet, jak i mężczyzn (Bauman 1995).

Innym istotnym elementem, o którym wspominali badani w kontekście czynników, które wpływają na ich wygląd, był styl życia, a dokładnie dwa jego aspekty - odżywanie i aktywność fizyczna. Na ogół uczestnicy badania, niezależnie od płci, mówili o tych dwóch czynnikach jednocześnie. Wszyscy wypowiadali się na ten temat w dość ogólny sposób, podkreślając, że to, jak wyglądamy, zależy od tego, czy jesteśmy aktywni fizycznie, czy uprawiamy sport, w jaki sposób się odżywiamy i czy prowadzimy zdrowy tryb życia. Na uwagę zasługuje fakt, że wśród młodych kobiet pojawiały się opinie o tym, że sposób odżywiania 
i regularna aktywność fizyczna mogą realnie wpłynąć na wygląd, a nawet „walczyć" $\mathrm{z}$ uwarunkowaniami genetycznymi. Jedna $\mathrm{z}$ wypowiadających się na ten temat kobiet, przyznała, że kiedy ma się predyspozycje na przykład do tycia, to aktywny i zdrowy tryb życia może pomóc w utracie zbędnych kilogramów (ona sama dzięki temu straciła ich aż 30) (KM_9_30). Inna dzięki regularnemu ćwiczeniu jogi i stosowaniu odpowiedniej diety, zdołała znacząco - w jej opinii - „wysmuklić” ciało (KM_12_34). Inna badana, tym razem w średnim wieku, nawiązała do obecnie panującego kultu szczupłego ciała i konieczności odchudzania się: „Wszędzie gdzie się nie obejrzysz, to są szczupłe laski, modelki, prezenterki. Wszystkie są szczupłe i wszystkie się odchudzają, więc takie czasy, no musisz dążyć to tego ideału, wręcz takie są wymagania. Ja staram się tę figurę utrzymać, jak mi się trochę przytyje, to od razu głodóweczka i jest ok" (KSR_4_45). Natomiast najstarsze uczestniczki badania podkreślały znaczenie aktywności fizycznej jako stałego elementu stylu życia, który wpływa w istotny sposób na nasz wygląd. Oto wypowiedź jednej z nich: "Całe życie chodziłam na jakieś ćwiczenia gimnastyczne takie czy inne, kiedyś tam uprawiałam sport, a jak ze sportem skończyłam, to właściwie nigdy nie przerwałam chodzenia na jakiś fitness" (KST_8_70). Ta sama respondentka zauważyła, że aktywność fizyczna rozładowuje przede wszystkim stres i różnego rodzaju frustracje, a to wpływa także na nasz wizerunek.

W przypadku mężczyzn najobszerniej i najczęściej o stylu życia, aktywności fizycznej i odżywianiu mówili mężczyźni młodzi: „To co jem, to w jaki sposób się odżywiam (wpływa na wygląd - przyp. aut.), to czy ćwiczę i jak dużo, jak bardzo jestem aktywny fizycznie" (MM_5_26), „Ma na pewno wpływ jak wyglądam - waga, ilość aktywności fizycznej, styl życia” (MM_10_31). Co ciekawe, odwoływali się także do stylu pracy jako czynnika warunkującego ich wygląd. Zwracali uwagę na rodzaj pracy, czy jest to praca umysłowa czy fizyczna. Jeśli cały dzień „siedzi się przy biurku", to ciało należy poddać treningowi siłowemu. A jeśli jest się pracownikiem fizycznym, nie trzeba już dodatkowo ćwiczyć czy uprawiać sportu, bo samo wykonywanie zadań takich jak podnoszenie, przenoszenie, dźwiganie różnych przedmiotów, wpływa budowanie masy mięśniowej i kształt sylwetki. Warto podkreślić, że w wypowiedziach najmłodszych badanych dało się zauważyć także niekorzystny wpływ, jaki na wygląd zewnętrzy ma ciężka fizyczna praca w trudnych warunkach: „Nieraz mam podkrążone oczy, bo jednak wymaga to trochę wysiłku. Czerwone, bo a coś nuż, widelec wpadnie do oka, mimo to że się ma okulary ochronne, ale to zawsze pył i inne rzeczy, które latają w powietrzu" (MM_8_29). Młodzi mężczyźni wyraźnie dostrzegali powiązanie atrakcyjności zewnętrznej z odpowiednim „rzeźbieniem sylwetki” 
poprzez aktywność fizyczną. Z kolei wśród mężczyzn w średnim wieku ta świadomość prowadzenia aktywnego ruchowo trybu życia, była związana zapobieganiu otyłości. Ważny okazał się także - ich zdaniem - czynnik bycia aktywnym umysłowo, co także korzystnie wpływa na wygląd (wygląda się „inteligentnie”). Pojawiły się także nieliczne wypowiedzi najstarszych biorących w badaniu mężczyzn, którzy zwracali uwagę na to, jak ważna jest sama świadomość prowadzenia odpowiedniego trybu życia. Oprócz aktywności fizycznej na drugim miejscu w ich opinii było utrzymanie tak zwanej dyscypliny żywieniowej, walki z łakomstwem, „nie obżeranie się”. Jeden $\mathrm{z}$ wypowiadających się na ten temat mężczyzn stwierdził: „Jak ktoś lubi dużo jeść i jest gruby, to i będzie wyglądał starzej i będzie misiowaty, a jak ktoś po prostu je, a nie obżera to będzie szczupły, będzie ruchliwy, prosty, jego chód będzie lekki" (MST_6_66).

We współczesnej kulturze ta „władza nad ciałem” ma istotne znaczenie, bo troska o ciało jest poddawana nie tylko instytucjonalizacji (na przykład poprzez uczestnictwo w klubach sportowych, zajęciach fitness, korzystania z usług salonów kosmetycznych czy poradni dietetycznych), ale przede wszystkim ulega silnej internalizacji norm bycia zdrowym, sprawnym, szczupłym (Szkudlarek 1993). Szczególnie jest to widoczne w opiniach najmłodszego pokolenia kobiet i mężczyzn, choć daje się także zauważyć w wypowiedziach osób w średnim wieku oraz starszych.

Nieliczni badani wskazywali również na aspekt ekonomiczny jako czynnik wpływający na wygląd. Płeć zdecydowanie różnicowała wypowiedzi w tym obszarze. Kobiety mówiły o znaczeniu finansów przede wszystkim w kontekście tego, czy kogoś stać, czy nie, na korzystanie z profesjonalnych zabiegów kosmetycznych lub częstotliwości chodzenia do salonów urody czy salonów fryzjerskich. Istotne dla nich było także to, że mogą sobie kupić dowolną ilość kosmetyków oraz ważna była ich jakość. Mężczyźni sygnalizowali wpływ „zasobności portfela” na to, jakiej jakości ubrania kupują. Podkreślali znaczenie czynników ekonomicznych w kontekście statusu społecznego i w jego konsekwencji dbania o odpowiedni strój: „To jak się ubierasz też jest ściśle związane z pieniędzmi, tak? Ponieważ jeżeli masz pieniądze, to ubierasz się, stać cię na więcej rzeczy i ubierasz się w to, co chcesz, a jeżeli nie masz pieniędzy, to ubierasz się $\mathrm{w}$ to, na co cię stać, $\mathrm{w}$ to, na ile sobie możesz pozwolić" (MM_5_26). W modelu patriarchalnym status mężczyzny był określany przez strój, jaki zakładał, a kobiety oceniane są głównie przez pryzmat urody. W tym kontekście czynniki ekonomiczne zdają się także podtrzymywać patriarchalną wizję modelu społeczeństwa.

Warto zauważyć, że wyłącznie kobiety zwróciły uwagę na jeszcze jeden czynnik wpływający na wygląd, a mianowicie stan zdrowia. Oto 
kilka wybranych wypowiedzi na ten temat: „To czy chorujemy ma wpływ na to, jak wyglądamy” (KM_11_34), „Przede wszystkim zdrowie, nie? Jak jest się zdrowym, to wygląd jest, uważam, że super” (KSR_14_61), "Choroby, to też na wygląd wpływa” (KST_16_89). Uczestniczki badania zdawały sobie także sprawę, że w przypadku kobiet istotną rolę w tym obszarze odgrywa gospodarka hormonalna, dzień cyklu menstruacyjnego ma wpływ na to, w jakiej kondycji są włosy i skóra. Niezależnie od wieku podkreślały, że na ten czynnik nie mają wpływu, bo jest on uwarunkowany biologicznie, indywidualne. Jedne kobiety dobrze znoszą czas okresu czy menopauzy, inne wprost przeciwnie. Wypowiedzi na temat związku zdrowia $\mathrm{z}$ wyglądem udzielały jedynie kobiety, co może świadczyć o ich wyższym poziomie refleksyjności i świadomości nakładania się tych dwóch aspektów na siebie wzajemnie niż ma to miejsce w przypadku mężczyzn.

Kilka osób zauważyło wpływ procesu socjalizacji na zachowania podejmowane na rzecz wyglądu. Mówili przede wszystkim o tym, że bardzo wiele nawyków przejmujemy od rodziców, tych dotyczących uprawiania sportu, sposobów odżywiania się, aktywnego stylu życia lub biernego, które polega na „leżeniu przed telewizorem”. Starsze respondentki przyznały, że wygląd zależy także od sposobu wychowania. Jedna z nich zawsze się buntowała przeciw swojej mamie, która „próbowała” ją wychować na "skromnie wyglądającą dziewczynę”, a ona lubiła się malować i często się buntowała przeciw decyzjom matki (KST_3_65). W tym przypadku mamy do czynienia $\mathrm{z}$ takim przejawem sprzeciwu $\mathrm{w}$ stosunku do patriarchalnego modelu kobiecości, w której młoda dziewczyna powinna wyglądać schludnie i skromnie, a nie „wyzywająco”. Mężczyźni $\mathrm{z}$ kolei przyznawali, że to przede wszystkim inni ludzie $\mathrm{w}$ ich otoczeniu mają wpływ na to, jak wyglądają. Kiedyś mieli rodzice, dziś ich żony, ale także współpracownicy. Warto zwrócić uwagę właśnie na tę rolę żony dbającej o wygląd swojego męża, wpisującej się w funkcjonowanie modelu patriarchalnego męskości. Pojawił się ciekawy przykład wypowiedzi na temat:

To tak, sprawy wyniesione $\mathrm{z}$ domu, od rodziców, że trzeba tam po prostu, zadbanym być. Zawsze uczesany, ogolony, czyste ciuchy, żeby to wszystko jakoś grało, wiadomo, że to podstawa [...]. Też osoba na przykład, z którą się przebywa na co dzień, czyli żona (ma wpływ na mój wygląd - przyp. aut.). Druga sprawa, że na co dzień się z ludźmi spotykam obcymi dla siebie, w związku z tym, też staram się jakoś wyglądać (MSR_8_53).

Starsze osoby - zarówno kobiety, jak i mężczyźni - uważały, że na nasz wygląd wpływa stopień aktywności towarzyskiej i intelektualnej. Regularne spotkania z innymi ludźmi - ich zdaniem - korzystnie oddziałują 
na nasz stosunek do dbania o siebie, przykładania wagi do ubioru, a także wpływają na psychikę:

Odmładzają mnie (śpiew w chórze - przyp. aut.) zdecydowanie, psychicznie przede wszystkim, jak najbardziej. Jak pani wychodzi do ludzi, to nie będzie pani nieuczesana, z brudnymi, tłustymi włosami. To mobilizujące, samo się nakręca, widzi pani, jak inne panie o siebie dbają, przychodzą też ładnie ubrane (KST_8_70). Musiałem dzisiaj czystą koszulkę założyć, bo z dziewczyną się mam spotkać (MST_12_72).

Inny starszy mężczyzna przyznał, że aby dobrze wyglądać, należy zachować „sprawność umysłową”, czytać książki, prasę, interesować się życiem społecznym i ciągle uczyć się nowych rzeczy (MST_11_71). Pojawiały się także nieliczne wypowiedzi dotyczące wpływu innych czynników na wygląd. Kilka osób wskazało na te, które są niezależne od człowieka na przykład wpływ środowiska zewnętrznego, przemian cywilizacyjnych, zanieczyszczonego powietrza, „chemicznych dodatków” do jedzenia. Były także sporadyczne wypowiedzi dotyczące wpływu pogody na nasz wygląd. Jednak nie dało się zaobserwować istotnych różnic w tym obszarze, biorąc pod uwagę czynnik upłciowionego wieku.

Podsumowując niniejszy rozdział, należy przyznać, że w przytaczanych przez kobiety i mężczyzn wypowiedziach można odnaleźć różnego typu odniesienia zarówno do tradycyjnego, jak i nowoczesnego modelu męskości i kobiecości. Jeśli chodzi o interpretację kwestii dotyczących biologicznych uwarunkowań wyglądu, to najmłodsi respondenci (i kobiety, i mężczyźni) najczęściej się do nich odwoływali, argumentując, że są podobni do rodziców obojga płci. W nowoczesnym modelu kobiecości i męskości, oba „pierwiastki” - żeński i męski - są traktowane jako równoprawne, choć różnorodne. Młodzi uczestnicy badań, nie utożsamiając się wyłącznie z rodzicem tej samej płci, zdają się dostrzegać i godzić na swoją własną różnorodność w tej kwestii, nie tylko samego wyglądu, ale także postaw wobec wyglądu. Inaczej ma się sprawa w odniesieniu do kobiet i mężczyzn w średnim i starszym wieku, którzy w swoich wypowiedziach nawiązują do podobieństwa lub jego braku, ale do rodzica tej samej co oni płci. Z kolei w wypowiedziach badanych w dwóch pozostałych kategoriach wiekowych (średniej i starszej) pojawiały się nie tylko pozytywne, ale i negatywne odniesienia do określonych cech wyglądu. Kobiety dziedzicząc po matkach na przykład piękną cerę bez zmarszczek czy gęste włosy były zadowolone i chętniej utożsamiały się z tymi cechami. Z kolei genetyczne dziedziczenie na przykład otyłości - która jest krytykowana we współczesnych przekazach kulturowych - było już postrzegane negatywnie. W przypadku mężczyzn te cechy, które były 
postrzegane jako pozytywne, a dziedziczone po linii męskiej, to: proporcjonalna i szczupła sylwetka, posiadanie włosów, młodzieńczy wygląd. Negatywnie postrzegana była ich opozycja - otyłość brzuszna, łysina i zakola. Zatem daje się tu zauważyć zmianę w kierunku androgynizacji wyglądu mężczyzn, którzy podążają za wymogami wyglądu stawianymi przez współczesne przekazy kulturowe. Kobiety natomiast pozostają w sferze wpływu patriarchalnego wzorca kobiecego wyglądu, nadal pootrzymywanego przez współczesną kulturę zachodu. Wyniki analizowanych tu badań wskazują, że choć obie płcie wskazywały na samopoczucie jako czynnik wpływający na ich wygląd, to dla kobiet ten aspekt miał o wiele większe znaczenie i częściej do niego nawiązywały w swoich wypowiedziach. Ponadto częściej mówiły o nastroju jako często niezależnego od siebie czynniku - dostrzegały to szczególnie te najmłodsze uczestniczki badania. Wpisuje się to zatem bardziej w tradycyjny model kobiecości, w którym emocjonalność kobiet odgrywa kluczową rolę. Należy jednak pamiętać, że kobiety w średnim wieku i te najstarsze są świadome własnej sprawczości w tym zakresie, oddziaływania na ten aspekt, co zdecydowanie wpisuje się już w nowoczesny model kobiecości, w którym kobieta jest podmiotem własnych emocji, a nie jedynie biernie się im poddaje. Tradycyjnemu modelowi męskości nie jest przypisana emocjonalność, uczuciowość. A jednak mężczyźni - choć w zdecydowanie mniejszym stopniu niż kobiety - do tego aspektu w swoich wypowiedziach nawiązują. Szczególnie ci najmłodsi badani, podając przykłady problemów życiowych, które w znaczący sposób wpływają na ich psychikę, a tym samym wygląd. Jednak niektórzy mężczyźni reprezentujący dwie pozostałe kategorie wiekowe także byli tego wpływu świadomi, co świadczy o realizowaniu przez nich w tym aspekcie raczej bardziej nowoczesnego modelu męskości.

Kwestia dbałości o swój wizerunek i zdrowy styl życia były istotne dla wszystkich kategorii badanych. W kontekście wyglądu wypowiedzi obu płci wpisywały się raczej w tradycyjny model kobiecości i męskości. Kobiety mówiły o makijażu, używaniu kosmetyków czy korzystaniu $\mathrm{z}$ profesjonalnych usług $\mathrm{w}$ tym zakresie, a wypowiedzi mężczyzn skupiały się na podstawowej higienie ciała, dbaniu o zarost i krótką fryzurę. Jeśli chodzi o zdrowy styl życia, w tym odpowiednie odżywianie się i aktywność ruchową, to można zauważyć, że zarówno kobiety, jak i mężczyźni wpisywali się raczej w zalecenia propagowane poprzez przekazy kulturowe mówiące o współcześnie obowiązującym kanonie urody - szczupłym i młodo wyglądającym ciele. W wypowiedziach obu płci da się zauważyć dążenie do pokonania oporu własnej biologiczności i poddawaniu się określonemu reżimowi odnoszącemu się i do odpowiedniej diety i aktywności ruchowej. Jeśli chodzi o kobiety, to nadal wpisuje się 
to w tradycyjny model kobiecości, w którym ciała kobiet stają się ciałami posłusznymi, ponieważ ulegają modzie na określony wygląd, ulegają presji społecznej, która jakoby wymusza na nich dopasowanie kształtu ciała do powszechnie obowiązującego wizerunku (Kaschak 2001). W przypadku mężczyzn zauważa się silniejszą androgynizację modelu męskości $\mathrm{w}$ tym aspekcie.

Okazuje się, że stawiane w tej pracy hipotezy, choć na ogół się potwierdzają, to jednak ich interpretacje różnią się od tych pierwotnie zakładanych. Nie tylko kobiety, ale także mężczyźni postrzegają wygląd jako zasób kapitału ludzkiego, który ma znaczący wpływ na ich społeczne funkcjonowanie. Krytyczność w ocenie własnego kapitału w tym zakresie jest charakterystyczna dla obu płci (nie tylko dla kobiet, jak zakładano). Jeśli chodzi o wiek, to faktycznie płeć słabo różnicuje postawy wobec wyglądu młodych ludzi. Ci, najbardziej cenią ten element kapitału ludzkiego. Trzeba jednak przyznać, że ich świadomość w tym zakresie, choć bardziej powszechna, niejednokrotnie jest także płytsza, mniej refleksyjna niż ma to miejsce u starszych uczestników badania, którzy poprzez swoje doświadczenia życiowe niejednokrotnie mają ciekawsze wnioski w tym temacie. Samoistnie zatem nasuwa się refleksja, że zachowanie młodości, sprawności, a przez to atrakcyjności fizycznej, zdaje się należeć do jednych z najważniejszych aspektów kapitału ludzkiego, którego są świadomi uczestnicy tego badania.

\subsubsection{Powody dbania o wygląd wskazywane przez kobiety i mężczyzn w różnym wieku (Ewa Malinowska)}

Niektóre z ustaleń poczynionych na gruncie psychologii, socjologii czy medycyny estetycznej dotyczących znaczenia wyglądu i jego społecznych funkcji, a także wyrosłych na tej bazie empirycznej teoretycznych uogólnień i przekonań na ten temat, znalazły potwierdzenie również w naszych badaniach. Przede wszystkim chodzi tu o uświadamianie sobie przez uczestniczki i uczestników tych badań wzrostu znaczenia wyglądu dla autooceny oraz jego wpływu na sposób oceniania nas przez innych. Zauważono ponadto wpływ atrakcyjnego wyglądu na nawiązywanie i przebieg relacji społecznych, występowanie praktyki określania „po wyglądzie" cech osobowości, na ogólnie lepsze traktowanie ludzi o ładnej powierzchowności we wszelkich sytuacjach społecznych (por. np. Bokszańska 2004: 80).

Wszystkie osoby biorące udział w wywiadach swobodnych, bez względu na płeć i wiek, uznały że zdecydowanie należy dbać o swój wygląd. Wśród kobiet (być może nieco zmęczonych obowiązkiem pamiętania 
o tym, że jest się oglądaną) pojawił się nieśmiało pogląd, iż nie powinna mieć miejsca przesadna troska o „zewnętrzność”, ponieważ jest to tylko jeden $\mathrm{z}$ aspektów „[...] społecznego naszego bytowania” (KM_12_34), a nadmierna troska o aparycję może prowadzić do osiągnięcia niezamierzonego efektu, jakim jest wygląd komiczny: „O wygląd należy dbać, ale też nie obsesyjnie, żeby nie wyglądać jak gwiazda cyrkowa. Normalny ubiór - dopasowany do urody, figury i pory roku też" (KM_13_34). Jeden z mężczyzn zastrzegł z kolei, że ta ważna skądinąd kwestia, nie jest jednak priorytetem życiowym (MM_12_32). Jednak nawet ludzie mający tak zdroworozsądkowe podejście do wyglądu nie zawsze mają odwagę zaprzeczyć sentencji wygłoszonej przez człowieka znanego nie tylko z bardzo zadbanego wyglądu - O. Wilde’a: „Tylko powierzchowni ludzie nie oceniają po wyglądzie" (za: Bokszańska 2004: 78).

Najczęściej wskazywanym przez respondentów płci obojga powodem dbania o swój wygląd była właśnie konieczność liczenia się z tym, jakie reakcje $u$ innych budzi nasz wizerunek oraz jaki wpływ na życie człowieka ma fakt, iż jest on postrzegany przez pryzmat wyglądu. Kobiety, nieco częściej niż mężczyźni, zauważały występowanie tendencji do oceniania na podstawie wyglądu również wiedzy, możliwości intelektualnych i kompetencji jednostki, słowem - osobowości: „[...] wygląd świadczy o człowieku, o całym jego jestestwie, że im jest bardziej zadbany tym lepiej odbierasz jego cały obraz ..." (KST_2_64). Reakcje otoczenia na wygląd jednostki kojarzono głównie z pozytywnym wpływem zadbanego wyglądu na relacje zawodowe, towarzyskie, osobiste. Człowiek o akceptowanym, ładnym wyglądzie łatwiej wchodzi w kontakty z innymi ludźmi, będąc wyżej ocenianym - jest lepiej traktowany, a to sprzyja realizacji jego celów życiowych, takich jak: zdobycie atrakcyjnej pracy, awansowanie, sukces ekonomiczny, znalezienie partnera/partnerki. Wygląd robiący dobre wrażenie był więc postrzegany jako ważny kapitał ludzki mający pozytywny wpływ na proces gromadzenia kapitału społecznego, co w końcu przekłada się przecież także na wielkość kapitału ekonomicznego, jakim dysponuje jednostka (Malinowska 2011). Osoby biorące udział w badaniu wspominały jednak także o negatywnym wpływie nieakceptowalnego wyglądu na sytuację społeczną człowieka. Dlatego tak ważne jest: „[...] żeby być estetycznym, żeby nie wzbudzać odrazy w otoczeniu, żeby ludzie nie odwracali głowy, jak się wchodzi do pomieszczenia [...]" (MSR_11_57).

Zgoda co do jego społecznej ważności nie przesądziła o całkowitym podobieństwie sposobu uzasadniania przez kobiety i mężczyzn dbałości o swój wygląd; interesujące różnice w wyjaśnianiu tej kwestii pozwoliło ukazać uwzględnienie w naszej analizie zmiennych takich, jak płeć, wiek i upłciowiony wiek (gendered age). 
Zaczynając prezentację wyników od uwzględnienia płci jako zmiennej różnicującej, możemy odnotować, że dotyczyły one po pierwsze hierarchii ważności rodzajów podawanych uzasadnień, a po drugie - sposobu rozumienia, często jednakowo brzmiących, argumentów używanych przez kobiety i mężczyzn.

Jeśli chodzi o pierwszą kwestię, dla kobiet i dla mężczyzn głównym powodem dbania o własny wygląd było, omówione wyżej, liczenie się z ocenami oraz reakcjami ,innych ludzi”. Na drugim miejscu kobiety wskazały własne samopoczucie - dobre, gdy zadbany wygląd wywołuje akceptację otoczenia, a mężczyźni - wskazali względy estetyczne. Na trzecim miejscu wśród powodów dbania o własny wygląd wymienianych przez kobiety znalazły się względy estetyczne, a u mężczyzn - dobre samopoczucie związane z dobrym wyglądem (Biorąc pod uwagę liczebność próby, porządek hierarchiczny nie jest oczywiście tak ważny jak sam fakt wskazywania przez obie płcie tych samych typów uzasadnień, ale był jednak zauważalny).

Jeśli chodzi natomiast o sposób rozumienia przytaczanych argumentów, wypowiedzi kobiet pozwalają przede wszystkim stwierdzić, że dla nich dbanie o własny wygląd jest czymś oczywistym, ale z drugiej strony powinnością, a nawet rodzajem misji. W ich wypowiedziach można więc było dostrzec wpływ patriarchalnego ideału kobiecości, w którym wygląd (a zwłaszcza uroda) jest elementem o podstawowym znaczeniu, podczas gdy ideał męskości koncentruje się na wskazaniu cech osobowości, cechy ciała, traktując jak swego rodzaju dopełnienie osobowościowych predyspozycji do sprawowania władzy, do dominacji (Melosik 1996: 241). Zinternalizowany przez kobiety obowiązek dbania $\mathrm{o}$ wygląd wydaje się więc się związany $\mathrm{z}$ rozwiniętą potrzebą zwracania na siebie uwagi aparycją. Być widzialną - znaczy istnieć. Takie przekonanie, zdaniem radykalnych feministek prowadzi do alienacji kobiety od jej ciała: „[...] podobnie jak pracownik najemny musi rywalizować $\mathrm{z}$ innymi pracownikami najemnymi o płacę, kobieta rywalizuje $z$ innymi kobietami o „męskie spojrzenie”, o męską aprobatę i uznanie” (Jaggar 1983: 309-310, za: Tong 2002: 165).

Mężczyźni biorący udział w badaniu dbanie o swój wygląd traktowali natomiast racjonalnie i instrumentalnie, jako dodatek do "męskiego" kapitału ludzkiego. Jak stwierdzali bowiem niektórzy z respondentów, atrakcyjny wygląd to tylko jeszcze jedna karta przetargowa, „as w rękawie", który może być wykorzystywany w grze o sukces na każdym polu aktywności społecznej - zawodowym, towarzyskim, relacji osobistych:

Jeśli ktoś jest singlem i szuka drugiej połowy, to na pewno będzie bardziej dbał o siebie niż facet, który ma związek i siedzi w domu komfortowo [...] 
(MM_15_37). W dzisiejszym społeczeństwie, jak zaznaczył inny z rozmówców, [...] ludzie cię oceniają na podstawie wyglądu. Podczas rozmowy o pracę, która jest też oceniana na podstawie wyglądu, [...], czy jesteś zadbany, itd. (MM_5_26).

Sięganie przez mężczyzn po kulturowo kobiecy kapitał ludzki równie dobrze można postrzegać jako reakcję na przeważający dziś udział kobiet w strategicznych zasobach do niedawna wyłącznie męskiego kapitału ludzkiego, czyli na liczebną przewagę kobiet w zbiorowości ludzi mających wyższe wykształcenie.

Tak samo brzmiące uzasadnienia konieczności dbania o własny wygląd wskazywane przez kobiety różnicował interesująco wiek respondentek.

Kobiety młode i w średnim wieku mówiły o konieczności dbania o wygląd ze względu na innych ludzi, dając wiele przykładów różnorodnych sytuacji, w których ma to ważne znaczenie. Analizując ich wypowiedzi, można dojść do wniosku, że młode kobiety były aż nazbyt przekonane o ogromnym i pierwszorzędnym znaczeniu wyglądu kobiety dla jej oceny jako człowieka (charakteru, umiejętności), oceny jako kandydatki na pracownika, dla postrzegania jej w kontekście życia towarzyskiego i jako potencjalnej partnerki życiowej itd. Co więcej, żadna z młodych kobiet nie wyraziła sprzeciwu wobec zaobserwowanej przez siebie praktyki utożsamiania akceptowanego wyglądu z pozytywnymi cechami osobowości ani wobec oceniania całego człowieka zaledwie/wyłącznie po wyglądzie. Wydawały się co najmniej nieświadome kulturowego charakteru tej normy, o jej dyskryminującej funkcji nawet nie wspominając.

Kobiety w średnim wieku i tylko one, zauważyły natomiast, iż społeczne znaczenie wyglądu bardzo wzrosło na przestrzeni ostatnich lat:

Bo zwłaszcza teraz od kilkunastu lat jest coś takiego jak cię widzą, tak cię piszą. I nie to, co w głowie, tylko to pierwsze wrażenie jest najważniejsze (KSR_7_49). Tak, zdecydowanie, bo jak cię widzą, tak cię piszą, oceniają. Teraz to tylko po wyglądzie i to myślę, że się nasiliło w ostatnim czasie, bardzo. Widzę też to po moich córkach, które bardzo zwracają uwagę na wygląd. Odchudzają się, zwracają uwagę na modę, na kosmetyki różne (KSR_4_45).

To spostrzeżenie może być uogólnionym doświadczeniem, a dokładniej wynikiem porównania własnych doświadczeń w tym zakresie, pochodzących $\mathrm{z}$ dwóch okresów życia respondentek: młodości - gdy były piękniejsze, ale nie miało to aż takiego znaczenia w życiu zawodowym - oraz obecnego - gdy atrakcyjny wygląd stał się cennym kapitałem, o który z wiekiem jest jednak coraz trudniej, podczas gdy społeczna presja na pozostawanie młodą i piękną wzrosła. U kobiet z tej kategorii wieku pojawiła się jednak także myśl, że zadbany wygląd pozwala uchodzić 
za młodszą niż się jest w rzeczywistości: „Staram się dobrze wyglądać. Dodatkowo pokazać, że jeszcze czterdziestopięciolatka może być atrakcyjna, że można być szczupłym i jako tako wyglądać" (KSR_4_45). Ponieważ uroda towarzyszy raczej młodości niż starości, a bycie ładną jest, kulturowo, obowiązkiem kobiety, dla kobiet w średnim wieku zaliczanie ich do kategorii ludzi młodych okazywało się bardzo ważne życiowo (tym bardziej że współcześnie, jak same zauważyły, nawet wiedza liczy się mniej niż atrakcyjny wygląd).

Jak już wspomniano, również stare kobiety wskazywały jako główne uzasadnienie potrzeby dbania o swój wygląd „innych ludzi”. W swych wypowiedziach akcentowały jednak nie tyle instrumentalne, co autoteliczne i społeczne znaczenie akceptowalnej, ładnej powierzchowności. Innymi słowy nie koncentrowały się na tym, co można uzyskać dzięki dobrej aparycji, lecz na tym, że wpływa ona korzystnie na relacje między ludźmi: ważne jest, aby być uważaną za osobę elegancką, zadbaną, bo z takim człowiekiem łatwiej wchodzi się w kontakt, a w dodatku lepsza ocena naszego wyglądu poprawia nam samopoczucie (por. Malinowska 2016).

Mężczyźni, do niedawna nie przywiązujący dużego znaczenia do swego wyglądu, gdyż budujący swą pozycję społeczną na podmiotowym statusie zapewniającym władzę i wszelkie prawa (m.in. prawo własności), a w rezultacie prestiż społeczny, pod wpływem pewnych tendencji charakteryzujących ponowoczesny patriarchat, dziś zwracają nań większą uwagę. Niektórzy badacze twierdzą nawet, że mężczyźni czynią to równie intensywnie jak kobiety (Bokszańska 2004: 148). Zwłaszcza młodsi z nich wiedzą doskonale, jak wzrosła ranga wyglądu (a jak zobaczymy, przynależność do kategorii wieku różnicowała ten stosunek w obrębie zbiorowości mężczyzn). Swoisty egocentryzm mężczyzn w podejściu do dbania o własny wygląd uwidocznił się na tle altruistycznego podejścia kobiet do wyglądu. Tylko kobiety bowiem, wyjaśniając na czym polega branie pod uwagę innych ludzi w dbaniu o własny wygląd, stwierdziły, że trzeba być osobą zadbaną, gdyż jest to miłe dla innych, dobrze wpływa na przebieg komunikacji z innymi. Nawet przynależność do tzw. płci pięknej niektóre respondentki traktowały jak zobowiązanie do ładnego wyglądu, bycia zadbaną, zgodnie z zasadą nobles oblige. Co ciekawe, takim spojrzeniem charakteryzowały się kobiety młode i stare. Pierwsze z nich bezrefleksyjnie (wobec seksistowskiego charakteru tej normy) podkreślały: „Wydaje mi się, że warto dbać o swój wygląd - zwłaszcza u kobiet - ponieważ jesteśmy troszeczkę napiętnowane tym sformułowaniem płeć piękna" (KM_9_30). Kobiety stare natomiast przypominały o powszechnym obowiązku dbania o siebie, podkreślając, że dotyczy on zwłaszcza kobiet: „Należy dbać. [...]. [...] powinno się dbać i każda kobieta powinna 
dbać o siebie" (KST_1_64) (ukazując zinternalizowanie płciowego różnicowania norm estetycznych, ale dotykając także równościowej koncepcji społecznych oczekiwań tego rodzaju).

Jak wspomniano, ważnym powodem starań o atrakcyjny wygląd było dla kobiet dążenie do pozytywnej samooceny; podkreślały wpływ zadbanego wyglądu na poprawę samopoczucia, na zyskiwanie pewności siebie. Wiek respondentek różnicował nieco stopień akcentowania tego aspektu. Stosunkowo najczęściej formułowały tę zależność kobiety będące w wieku średnim (ponad połowa z tej kategorii), a następnie młode (jedna trzecia) i nieco rzadziej stare (prawie jedna trzecia). Poszukując wyjaśnienia tego zjawiska, można odwołać się do patriarchalnego uzależnienia u kobiet poczucia własnej wartości od oceny uzyskiwanej od innych. Na nasuwające się tu pytanie, dlaczego najbardziej konsekwentnie socjalizowane patriarchalnie stare kobiety, wydają się, w świetle swych wypowiedzi, najbardziej wyemancypowane od wskazanej zależności, nie znaleziono odpowiedzi w zebranym materiale. Może miał tu wpływ, wynikający już z doświadczenia, sceptycyzm wobec możliwości budowania poczucia własnej wartości na ocenie „za wygląd”, gdy się jest już starym?

Tylko mężczyźni natomiast, bez względu na wiek, mówiąc że „trzeba dbać o wygląd ze względu na innych ludzi”, mieli na myśli również to, że inni powinni być zadbani, aby kontakt $\mathrm{z}$ nimi był przyjemny: „[...] każdy czerpie większą przyjemność z kontaktu z jakąś czystą, zadbaną osobą niż z panem żulianem spod sklepu, który śmierdzi czasem, no jest brudny, nawet nie uścisnęłoby mu się dłoni [...]” (MM_1_21). Wskazywanymi przez mężczyzn „innymi” często były kobiety:

Wygląda się dobrze dla siebie, wygląda się dobrze bo chce się podobać [...] albo generalnie płci przeciwnej, teraz też niektórzy płci swojej, albo chcę się podobać swojej partnerce [...] i w ogóle (jest - przyp. aut.) taki kult dobrego wyglądu (MSR_1_38). To jest niezbędna rzecz. Jesteśmy wzrokowcami. Fajnie się rozmawia $\mathrm{z}$ miłą, sympatyczną, atrakcyjną brunetką ładnie pachnącą. Może tu jest kwestia, że wywodzimy się od zwierząt, że taki instynkt samozachowawczy, że samiec zwróci uwagę na partnerkę, która będzie przyciągała jego uwagę chociażby zadbanymi włosami, ładnymi paznokciami (MSR_5_46). Powinien (człowiek dbać o wygląd - przyp. aut.), bo ja na przykład bardzo lubię patrzyć się na naprawdę ładne dziewczyny, ładnie zbudowane, zresztą jestem plastykiem [...]; Tak, bardzo (należy dbać - przyp. aut.). Zawsze jest przyjemnie, jak ja widzę panią tak gustownie ubraną np. drobniutka, szczuplutka, wie pani jak to jest przyjemnie (MST_12_72).

Jak już wspomniano, wśród pozostałych powodów dbania o wygląd na drugim miejscu mężczyźni wskazywali względy estetyczne. Najczęściej wymieniali ten powód starzy mężczyźni, pojawił się on jednak także w wypowiedziach mężczyzn w średnim wieku. Wyjątek stanowili młodzi 
mężczyźni, z których żaden nie wymienił takiego powodu dbania o swój wygląd. Czy dlatego, że młodość po prostu jest piękna? Na trzecim miejscu w zbiorowości mężczyzn wymieniono jako powód dbania o wygląd własne samopoczucie, łącząc je niekiedy z dodatnim wpływem na zdrowie psychiczne, ogólną kondycję mężczyzny i jego sprawność (tak twierdzili przede wszystkim młodzi mężczyźni):

Zresztą, jak człowiek dobrze wygląda, jak o siebie dba to, przypuszczam, też to ma wpływ na jego zdrowie psychiczne. Tak, że to idzie w parze. Taki tandem (MM_7_28). Ja bardziej pod uwagę biorę [...] wydolność organizmu i tego typu rzeczy, [...]. Mnie chodzi o to, żeby być ogólnie sprawnym, ponieważ jeżeli już się jest tym sprawnym, to jest się dłużej młodym (MM_5_26).

Jeśli niektórzy mężczyźni postrzegali dbanie o wygląd podobnie jak kobiety, tzn. w kategoriach powinności, to jednak mieli wtedy na względzie nie siebie, lecz obowiązek każdej innej osoby, bez względu na płeć. W ten sposób postrzegali ów problem głównie starzy mężczyźni.

Tylko jedna z kobiet, reprezentująca kobiety w średnim wieku, zresztą jako jedyna wśród respondentów obu płci, zauważyła, iż zadbanym wyglądem okazujemy innym szacunek: „Osoby zupełnie inaczej też nas odbierają, bo przyjemniej jest patrzeć na osobę schludną i fajnie wyglądającą niż na osobę zaniedbaną. Tak, że no, o wygląd trzeba dbać. Zresztą moim zdaniem wygląd to jest szacunek dla otoczenia" (KSR_14_61).

Podsumowując ten fragment (przy zachowaniu ostrożności podyktowanej liczebnością próby i charakterem badania), można stwierdzić, że głównym uzasadnieniem dbałości o wygląd wskazywanym przez naszych respondentów - bez względu na płeć i wiek - było to, że inni oceniają nas po wyglądzie oraz fakt, że ta ocena dotyczy "całego" człowieka i ma znaczenie dla jego społecznego funkcjonowania. Subtelne różnice w sposobie rozumienia przez kobiety i mężczyzn praktycznego znaczenia tych ocen sprawiały, że kobiety były w swych staraniach bardziej ukierunkowane na uzyskanie akceptacji ze strony innych, a mężczyźni - bardziej na zrobienie wrażenia, na wykorzystanie swego atrakcyjnego wyglądu jako dodatkowego atutu w relacjach z ludźmi. Ponadto mężczyzn interesował nie tylko (a czasem nie tyle) zadbany wygląd własny co wygląd innych, zwłaszcza kobiet, traktowany w tym przypadku jako element, osobiście dla nich ważnej, estetyki otoczenia.

Analiza powodów dbania o wygląd w obrębie każdej z trzech kategorii wieku, pozwoliła $\mathrm{z}$ kolei zauważyć podobieństwo między wypowiedziami młodych ludzi. Tutaj jednakowa okazała się nawet hierarchia ważności wskazywanych powodów: kobiety i mężczyźni wymienili przede wszystkim liczenie się z ocenami innych ludzi oraz na drugim miejscu - dbanie 
o wygląd ze względu na samego/samą siebie, własne samopoczucie. Ważne podobieństwo obejmowało także instrumentalne podejście do własnego wyglądu prezentowane przez młodych ludzi: wygląd traktowali oni jako kartę przetargową w realizacji planów życiowych:

[...] no należy dbać o swój wygląd, wygląd to jest też wizerunek, jak nas ludzie postrzegają, jak jesteśmy zadbani, to możemy łatwiej przebić się w świecie, no niestety w dzisiejszych czasach jest to bardzo intensywnie postrzegane przez innych, jak wyglądamy (KM_10_30). W obecnych czasach ludzie często zwracają bardziej uwagę na wygląd, niż na charakter i osobowość. I dlatego trzeba o niego dbać (MM_3_22).

Mówiąc o konieczności dostosowania wyglądu do sytuacji, mężczyźni wymieniali głównie obszar pracy zawodowej, a kobiety również obszar prywatny - relacje towarzyskie i intymne. Wśród wypowiedzi udzielonych przez mężczyzn znalazła się i taka, iż dobry wygląd pełni funkcję stratyfikującą: „No jest naszą wizytówką, jakby nie patrzeć. Wygląd wpływa na nasze umiejscowienie w grupie, no i na pewno wpływa na to, jak nas inni postrzegają" (MM_8_29). W kulturze patriarchalnej, w grupie mężczyzn, ważnym czynnikiem stratyfikującym był wiek. Biorąc pod uwagę przeciwne ukierunkowanie pozytywnego oddziaływania wskazanych czynników, warto zauważyć, że dziś atrakcyjny wygląd pozwala „młodemu wilkowi” konkurować ze starszym mężczyzną (nie dysponującym na ogół tego typu kapitałem w podobnym stopniu) o jego dominującą pozycję. Młode kobiety mówiły z kolei o dodatnim wpływie atrakcyjnego wyglądu na pewność siebie, co także ma znaczenie w procesie osiągania celów życiowych.

Młodzi ludzie podkreślali także zgodnie obowiązek dbania o swój wygląd. Różnica polegała na tym, że mężczyźni sformułowali te zasadę generalnie („każdy powinien”), a w wypowiedziach kobiet pojawiał się patriarchalny resentyment $\mathrm{w}$ postaci przypisania szczególnej powinności bycia zadbanymi kobietom jako „płci pięknej”.

Płeć nie różnicowała wyraźnie wypowiedzi kobiet i mężczyzn reprezentujących w naszym badaniu kategorię ludzi w średnim wieku: wszyscy oni zgodnie uzasadniali potrzebę dbania o swój wygląd koniecznością liczenia się z opiniami innych ludzi, oceniającymi nas na tej podstawie. Dla ludzi w średnim wieku wygląd okazał się ważny zwłaszcza w relacjach zawodowych, „w świecie pracy”. Kobiety i mężczyźni w średnim wieku zauważyli ponadto, iż ocenianie ludzi po wyglądzie nie jest stosowną praktyką, a nawet może prowadzić do błędnych wniosków. Taka opinia może mieć związek z tym, iż w młodości osób dziś będących w średnim wieku (38-62 lata) wygląd nie grał jeszcze takiej roli, jak ma to miejsce obecnie. Najbardziej widoczne różnice między wypowiedziami kobiet i mężczyzn 
ujawniły się w obrębie kategorii ludzi starych (por. Malinowska 2016). Tylko mężczyźni podkreślali konieczność dbania o wygląd, zwłaszcza o strój, odpowiednio do stanowiska i charakteru pracy: „Tak, bo jak cię widzą tak cię piszą. Jak chodziłem do pracy, to musiałem mieć marynarkę, bo to od razu inaczej się wygląda. Poważniej, bardziej na stanowisku. W końcu brygadę pod sobą miałem, zarządzałem nimi, więc też musiałem jakoś wyglądać. Oni w roboczych ubraniach chodzili, a ja byłem w biurze, musiałem inaczej" (MST_8_70.). Stare kobiety odróżniały raczej różne dziedziny aktywności, okazje, do których dopasowuje się swój wygląd, ubiór, jak np.: wyjście do pracy, do kościoła, na spotkanie z koleżanką czy też po zakupy. „No nie zawsze też w danym dniu człowiek ma taki nastrój, by tak elegancko tak wyglądać. No bo jak się idzie po zakupy, czy po coś, to trudno ubrać się elegancko i iść na rynek po zakupy" (KST_1_64). Ten sposób myślenia odzwierciedla genderowo uwarunkowane zróżnicowanie znaczenia, jakie kobiety i mężczyźni tego pokolenia przypisywali aktywności w każdej ze sfer życia: dla nich ważniejsza była sfera publiczna, gdzie głównie się realizowali i oczywiście kariera zawodowa, a dla kobiet - co najmniej jednakowo ważne były obie przestrzenie, bo choć należące już do pokolenia kobiet masowo obecnych na rynku pracy, respondentki były równocześnie głównie odpowiedzialne za funkcjonowanie domu i rodziny.

W tym miejscu warto przypomnieć, że z kolei młodzi mężczyźni mówili o wpływie wyglądu na pozycję zajmowaną w grupie, a młode kobiety zauważyły znaczenie atrakcyjnego wyglądu jako zwiększającego szanse awansu. Kobiety w średnim wieku i starsze nie łączyły wyglądu $\mathrm{z}$ funkcjonowaniem w ramach jakiegokolwiek porządku hierarchicznego.

Starzy ludzie zwracali uwagę na znaczenie akceptowalnego wyglądu dla jakości relacji z innymi ludźmi (por. Malinowska 2016). Tylko starzy mężczyźni podkreślali natomiast znaczenie estetycznego wyglądu kobiet dla zaspokojenia męskich potrzeb estetycznych; jeden zwrócił nawet uwagę, że miły, ładny wygląd partnerki/partnera interakcji modyfikuje ich zachowania. „My poprzez swój wygląd oddziałowujemy na drugą osobę [...]. Jeżeli osoba, z którą się spotykamy, jest osobą miłą, jest osobą uśmiechniętą, to nawet gdybyśmy mieli do niej jakieś pretensje, to te pretensje są trudne do wyartykułowania [...]" (MST_4_64). Podkreślali również, że zadbany wygląd dodaje im pewności siebie. Jednocześnie, podobnie jak mężczyźni i kobiety będący w średnim wieku, starzy mężczyźni mieli świadomość, że ocena człowieka po wyglądzie nie jest stosowną, gdyż jest zawodną praktyką.

Tylko starzy ludzie obojga płci (oraz młode kobiety) połączyli dbanie o wygląd $\mathrm{z}$ oddziaływaniem prozdrowotnym, choć starzy mężczyźni definiowali dbanie o wygląd jako wykonywanie elementarnych 
czynności, związanych z utrzymywaniem higieny osobistej. Z kolei tylko kobiety - młode i stare - uznały dbanie o wygląd głównie za powinność kobiet: „Ale powinno się dbać i każda kobieta powinna dbać o siebie” (KST_1_64); „Wydaje mi się, że warto dbać o swój wygląd - zwłaszcza u kobiet - ponieważ jesteśmy troszeczkę napiętnowane tym sformułowaniem "płeć piękna«" (KM_9_30). Można przypuszczać, że kobiety młode odwoływały się tu do ogólnego wymogu posiadania dobrej aparycji, dotyczącego współcześnie także ich rówieśników. Badane reprezentujące stare kobiety, nawiązywały natomiast do „tradycyjnego", patriarchalnego kulturowego modelu płci, w przypadku kobiet zawierającego obowiązek „bycia piękną", tzn. podobania się.

Tak więc, wyniki analizy wypowiedzi kobiet i mężczyzn będących $\mathrm{w}$ różnym wieku na temat powodów dbania o swój wygląd pozwalają uznać za uzasadnione przypuszczenie tę część pierwszej hipotezy, która mówi, że na ogół kobiety chętniej niż mężczyźni postrzegają wygląd jako zasób kapitału ludzkiego mający znaczący wpływ na ich społeczne funkcjonowanie. Uwzględnienie gendered age jako kategorii analizy pozwoliło jednak wskazać interesujące zróżnicowanie wypowiedzi w obrębie zbiorowości mężczyzn.

\subsection{Komponent afektywny}

\subsubsection{Ocena własnego wyglądu a płeć i wiek (Joanna Brzezińska)}

Współcześnie w kulturze zachodniej wysoko cenione są młodość i piękno. Żyjemy w czasach zdominowanych przez kult młodości, a idący w sukurs postęp medycyny pozwala nie tylko na znaczące wydłużenie średniej długości życia, ale i na skuteczniejszą walkę z fizycznymi i biologicznymi oznakami starzenia się. W społeczeństwach ponowoczesnych w dużym stopniu ciało determinuje społeczną tożsamość jednostki i jako nośnik norm i wartości wpływa na jej społeczny status i atrakcyjność interpersonalną (Jakubowska 2009a; Wolf 2014). Subiektywnie i kulturowo oceniana uroda jednostki jako najbardziej publiczna część jaźni w znacznym stopniu decyduje o tym, na ile stajemy się atrakcyjni nie tylko siebie, ale przede wszystkim dla innych (Etcoff 2002).

Aby zbadać, w jaki sposób postrzegają swoją powierzchowność ludzie młodzi, w wieku średnim oraz starzy, a także ustalić, do czego 
odwołują się w tych subiektywnych opiniach, poproszono o ocenę własnego wyglądu kobiety i mężczyzn reprezentujących ww. kategorie wiekowe, którzy wzięli udział w wywiadach swobodnych. Odpowiedzi respondentek i respondentów udzielone na pytanie o to, czy uważają siebie za osobę atrakcyjną, można zakwalifikować do trzech głównych kategorii: oceny pozytywnej, negatywnej oraz neutralnej. Wypowiedziało się dziewięćdziesiąt kobiet i mężczyzn w trzech przedziałach wiekowych: młodości, wieku średniego i starości.

Wśród stanowisk odnoszących się do autooceny wyglądu w grupie kobiet przeważały opinie pozytywne, podczas gdy wśród mężczyzn najczęściej formułowano zdania neutralne i pozytywne. Warto zwrócić uwagę na fakt, iż negatywny sposób postrzegania własnego wyglądu i atrakcyjności w obu zbiorowościach płci obserwowano rzadko, przy czym surowiej i ze zdecydowanie mniejszym przekonaniem o własnej atrakcyjności oceniały siebie badane kobiety. Powyższe ogólne wnioski wydają się spójne z rezultatami ogólnospołecznych badań zadowolenia Polaków i Polek z tego, jak wyglądają, zgodnie z którymi ponad trzy czwarte mieszkańców Polski (76\%) akceptuje swój wygląd i wyraża zadowolenie z własnej sylwetki, nieco ponad jedna piąta ankietowanych (22\%) nie jest zadowolona $\mathrm{z}$ własnego wyglądu, $\mathrm{w}$ tym co dwudziesty respondent (5\%) całkiem nie akceptuje swojej fizyczności (CBOS 2009b). Podobnie w skali kraju dużo częściej zadowoleni z własnego wyglądu są mężczyźni: 85\% głosów akceptacji, przy $14 \%$ niezadowolenia, podczas gdy kobiety prezentują zdecydowanie bardziej krytyczny stosunek wobec siebie: $67 \%$ aprobaty, $30 \%$ dezaprobaty dla własnego wyglądu (CBOS 2009b).

Analizując wypowiedzi respondentek, które pozytywnie oceniły swoją powierzchowność, daje się zauważyć, iż dominują wśród nich opinie wyważone, niepozbawione wątpliwości, zdradzające brak pewności siebie:

Tak (uważam się za osobę atrakcyjną - przyp. aut.), tzn. bardziej atrakcyjną niż mniej atrakcyjną (KM_6_28). Trzymam, trzymam wagę. Ogólnie jest w porządku, zupełnie normalna budowa, pospolita (KM_8_29). Oceniam się pozytywnie. Myślę, że jestem w miarę atrakcyjna, że niczego mi nie brakuje (KSR_4_45). Uważam, że nie wyglądam źle [...] można tak powiedzieć, że jestem atrakcyjna $\mathrm{z}$ wyglądu (KSR_6_48).

Natomiast mężczyzn wypowiadających się pozytywnie na temat własnego wyglądu wyróżniała wyraźna samoakceptacja, której próżno szukać w cytowanych wyżej wypowiedziach respondentek, co ilustrują m.in. deklaracje: „(Jestem - przyp. aut.) zadowolony (z wyglądu - przyp. aut.), nigdy nie miałem kompleksów z tego powodu (MSR_15_61). „Takie to będzie trochę bałwochwalstwo, ale uważam siebie za atrakcyjnego mężczyznę, kiedyś za chłopaka, teraz za atrakcyjnego mężczyznę" (MSR_6_47). 
"Czuję się w swojej skórze dobrze” (MSR_8_53). Niemniej niektórzy mężczyźni - podobnie jak większość badanych kobiet - wydawali mniej zdecydowane autooceny i w ich wypowiedziach można zaobserwować brak bezwarunkowej akceptacji własnego wyglądu, o czym świadczą opinie poprzedzone stwierdzeniem „wydaje mi się...”, „myślę...”, „raczej...” lub zawierające warunek („uważam się za atrakcyjnego, ale...”) sugerujące konieczność poprawy lub zmiany pewnego aspektu wyglądu lub podjęcia jakiejś aktywności zmierzającej do korekty wyglądu: „Wydaje mi się, że w skali od 1 do 5 oceniłbym siebie na $4 \mathrm{z}$ małym plusem. Czyli uważam się za osobę atrakcyjną" (MM_4_24). „Jestem zadowolony, natomiast brakuje trochę czasu, żeby trochę zadbać o sylwetkę. Tak, że jak miałbym trochę więcej czasu, to na pewno mógłbym popracować nad sobą" (MM_13_32). Należy jednak podkreślić, że mężczyźni uczestniczący w wywiadach swobodnych rzadziej postrzegają swoją atrakcyjność w sposób warunkowy aniżeli kobiety.

Wspomniana różnica w ocenie własnej atrakcyjności przez respondentki i respondentów wynika z patriarchalnej nierówności koncepcji obu płci. Jak zauważa Adam Buczkowski za E. Tseelon, kobiety w porównaniu do mężczyzn podlegają dużo surowszej krytyce, jeśli chodzi o atrakcyjność fizyczną, która w myśl patriarchalnej koncepcji płci ma większy wpływ na ich życie oraz funkcjonowanie w społeczeństwie. $\mathrm{Z}$ tego względu kobiety zdecydowanie surowiej postrzegają własną powierzchowność aniżeli mężczyźni, gorzej oceniają własne ciało w porównaniu do mężczyzn i są mniej zadowolone z własnej sylwetki (Buczkowski 2005: 286). Uczestniczki badania znacznie częściej, nawet pozytywnie oceniając swój wygląd, asekurują swoje osądy brakiem przekonania co do ich słuszności nieśmiałością i pokorą, często uzasadniając swoją pozytywną ocenę aktywną postawą wobec wyglądu, podejmowaniem działań na rzecz zachowania, poprawy, pielęgnacji tego zasobu: „ogólnie jestem zadowolona (z wyglądu - przyp. aut.), ale dlatego, że dbam o to" (KM_5_28); „Trzymam wagę, więc jestem atrakcyjna” (KM_8_29). Choć niektórzy badani mężczyźni również warunkowali oceny własnego wyglądu, tego typu wypowiedzi miały charakter marginalny, co potwierdza, iż wygląd zewnętrzny stanowi dopełnienie patriarchalnej koncepcji męskości, na którą składają się przede wszystkim określone cechy osobowe i role społeczne, nie jest zaś podstawą jej kształtowania - jak to ma miejsce w przypadku patriarchalnej koncepcji kobiecości. Stąd być może także liczne neutralne oceny własnego wyglądu wśród mężczyzn, niezależnie od wieku, których wypowiedzi świadczą o mniejszej autorefleksji, braku potrzeby konkurencji oraz mniejszym znaczeniu tego zasobu: „Uważam, że wyglądam normalnie, dobrze, jak zwyczajny, szary człowiek” (MM_3_22); „Jestem normalny, niczym niewyróżniający się 
z tłumu” (MM_5_26); „Chyba jestem normalny, ani atrakcyjny, ani nie jestem nie..., ani nieatrakcyjny jestem” (MSR_13_60); „Nie jestem ostatnim ani pierwszym, (jestem - przyp. aut.) w środku" (MST_12_72).

$\mathrm{W}$ przeważającej mierze mężczyźni oceniali siebie neutralnie albo pozytywnie, wykazując jednak ogólne zadowolenie z własnego wyglądu (MM_1_21, MM_3_22, MM_5_26 MM_7_28, MST_12_72, MST_13_77). Kobiety natomiast, mówiąc o neutralnej ocenie własnej, przyznawały, że są częściowo zadowolone z wyglądu i podkreślały swoją „przeciętność”, „Zwykłość” i podobieństwo do innych. Neutralna ocena własnej powierzchowności w przypadku obu badanych zbiorowości płci wiązała się z określaniem siebie przez pryzmat niewyróżniania się i „normalności”.

Rozpatrując negatywne oceny własnej atrakcyjności deklarowane przez kobiety, można zauważyć, że były one formułowane zarówno jako ogólne niezadowolenie $\mathrm{z}$ własnego wyglądu lub jego konkretnych przejawów: nadwaga, mała sprawność fizyczna, brak czasu na dbanie o siebie, jak i jednoznaczne zdefiniowanie siebie jako osoby nieatrakcyjnej lub mało atrakcyjnej (KSR_8_53, KST_3_65, KST_4_66, KST_8_70, KST_14_86). Jedna z respondentek uznała proces starzenia się z jego niekorzystnym wpływem na ciało i zdrowie, jako powód rozczarowania własnym wyglądem: „Jestem bardzo niezadowolona [...], bo się starzeję [śmiech] w szybkim tempie i właśnie zdrowie mi też odmawia posłuszeństwa, no i z tego powodu nie zawsze się dobrze czuję" (KSR_10_56).

Negatywne oceny wyglądu i atrakcyjności pojawiały się również w wypowiedziach mężczyzn uczestniczących w wywiadach swobodnych, jednakże znacznie rzadziej badani niezależnie od wieku oceniali nisko swoją powierzchowność, wskazując na ogólną dezaprobatę oraz kompleksy dotyczące wyglądu: „Oceniam swój wygląd negatywnie [...], bo mógłbym lepiej wyglądac”” (MSR_10_56), „nisko oceniam, bo jestem realistą" (MSR_11_57). Podobnie jak w grupie badanych kobiet tylko jeden respondent - mężczyzna $\mathrm{z}$ najstarszej kategorii wiekowej - negatywną ocenę własnego wyglądu wiązał $\mathrm{z}$ wiekiem metrykalnym i zmianami spowodowanymi starzeniem się skóry twarzy: „No nie (jestem zadowolony ze swojego wyglądu - przyp. aut.). Widzę zmarszczki coraz większe i to mnie postarza" (MST_12_72).

Analizując wypowiedzi respondentek i respondentów reprezentujących trzy kategorie wiekowe, można dostrzec, iż czynnik wieku różnicuje opinie zarówno kobiet, jak i mężczyzn o ich własnym wyglądzie. $\mathrm{W}$ pierwszej kolejności scharakteryzowane zostaną różnice $\mathrm{w}$ autoocenach w ramach zbiorowości kobiet, a następnie w ramach zbiorowości mężczyzn. W ostatniej części podrozdziału przedmiotem refleksji będą opinie charakterystyczne dla poszczególnych grup wiekowych bez względu na płeć. 
Choć zdecydowana większość respondentek pozytywnie oceniła swój wygląd zewnętrzny, zauważalna jest tendencja, iż młode kobiety częściej mówiły o swojej atrakcyjności w korzystnym świetle niż kobiety w średnim wieku i stare. Żadna z młodych kobiet nie wyraziła bowiem jednoznacznej dezaprobaty dla swojej aparycji. Można przypuszczać, iż taki stan rzeczy wynika $z$ relatywnie pozytywnego nastawienia młodych respondentek do kwestii atrakcyjności fizycznej i ich biologicznie młodego wyglądu. Warto jednak zwrócić uwagę, że oceny kobiet młodych są bardziej wyważone i charakteryzuje je mniejsza pewność osądu niż kobiet $\mathrm{z}$ dwóch starszych grup wiekowych. Podczas gdy młode respondentki wypowiadały się o swoim wyglądzie w sposób zachowawczy: „Ogólnie jestem zadowolona, ale dlatego, że dbam o to" (KM_5_28), kobiety reprezentujące starsze kategorie wiekowe wyrażały większą akceptację dla swojego wyglądu: „Myślę, że jestem w atrakcyjna, że niczego mi nie brakuje” (KSR_4_45); „uważam, że jestem ok, nie mam żadnych, nie mam żadnych kompleksów" (KST_8_70).

Negatywne opinie na temat własnej fizycznej atrakcyjności pojawiły się wyłącznie wśród kobiet w średnim wieku oraz starych. Choć niektóre badane z grupy wiekowej 38-62 lata uzasadniały swój osąd argumentem, iż nikt do końca nie jest zadowolony ze swojego wyglądu, były wśród nich wyraźnie krytyczne głosy względem własnej powierzchowności: „Ja siebie oceniam bardzo negatywnie” (KSR_7_49); „Jestem bardzo niezadowolona" (KSR_10_56). Nieco łagodniej, choć wciąż ujemnie, postrzegały siebie kobiety stare, formułując autooceny zarówno jako ogólne niezadowolenie z wyglądu, jak i konkretnych jego elementów: „Nie jestem jakąśs taką pięknej urody, wyglądu, sylwetki. Taka jestem, jaką mnie Pan Bóg stworzył” (KST_3_65); „No, nieraz jestem niezadowolona (z wyglądu - przyp. aut.), bo jak pod tymi oczami te woreczki mi się takie zrobią" (KST_14_86). W świetle powyższego można wysunąć przypuszczenie, iż ogólna samoocena atrakcyjności wśród kobiet spada wraz z wiekiem i opiera się na innych przesłankach w zależności od metryki - w przypadku kobiet w średnim wieku i starych wynika z ogólnego samopoczucia, sprawności fizycznej, tj. czynników biologicznych i kondycyjnych, a nie estetycznych, co częściej charakteryzuje wypowiedzi młodych respondentek i zostanie szerzej omówione w kolejnym podrozdziale.

Znaczna część badanych oceniła swój wygląd w sposób neutralny, ale nieco częściej takie stanowisko prezentowały kobiety w średnim wieku i stare. Respondentki te w podobny sposób określały własną powierzchowność za pomocą takich przymiotników jak „przeciętny”, „średni”, „niewyróżniający się”: „No taką bardzo atrakcyjną to nie jestem. Jestem taka po środku. Ani atrakcyjna, ani nie atrakcyjna" (KSR_15_62); 
„Uważam się za przeciętną” (KST_12_84), „Nie jestem atrakcyjna ani nie atrakcyjna. Jestem tak pół na pół” (KST_1_64).

Zróżnicowane podejście do oceny wyglądu wśród starszych grup wiekowych respondentek może wynikać z faktu posiadania przez nie dłuższego i bogatszego doświadczenia życiowego, większej świadomości własnego ciała lub dystansu do atrakcyjności własnej, budowanej nie tylko na samej fizyczności, ale i cechach osobowych, a także z mniejszego znaczenia wyglądu zewnętrznego dla autooceny jednostki. Jak zauważa Lidia Anna Wiśniewska, w literaturze przedmiotu nie ma również zgodności co tego, jak wygląda subiektywna ocena zadowolenia $\mathrm{z}$ ciała u starzejących się kobiet, a niektórzy badacze podkreślają wręcz, że rezultaty licznych studiów są różnorodne i nierzadko sprzeczne i nie sposób wyciągnąć jednoznacznych wniosków (Wiśniewska 2014; por. Ferraro i in. 2008; Głębocka 2009). Psychologowie społeczni na podstawie analizy wyników badań sugerują przeciwstawne trendy: z jednej strony spadek zadowolenia $\mathrm{z}$ ciała, $\mathrm{z}$ drugiej zaś wzrost satysfakcji tłumaczony tendencją do bardziej realistycznych oczekiwań i autoocen kobiet w wieku średnim i starych (Wiśniewska 2014), co znajduje swoje odzwierciedlenie również $\mathrm{w}$ cytowanych $\mathrm{w}$ tym podrozdziale pozytywnych, neutralnych oraz negatywnych wypowiedziach respondentek $\mathrm{z}$ dwóch starszych kategorii wiekowych na temat własnego wyglądu zewnętrznego.

We współczesnej kulturze dominują ujemne stereotypy dotyczące osób starszych i procesu starzenia się i dotyczą one m.in. zwiększającej się masy ciała i fizycznej ułomności, w tym spowolnionych ruchów, utraty elastyczności skóry czy siwiejących włosów (por. Głębocka 2009). W tym kontekście mówi się również o zjawisku „podwójnego standardu starzenia się", gdyż społeczeństwa deprecjonują starsze kobiety, które są odbierane jako mniej atrakcyjne względem mężczyzn w podobnie zaawansowanym wieku, których dojrzałość jest cechą dodatnią i pożądaną (Sontag 1972; Miluska 1996). Stereotypy - zgodnie z którymi starość jest brzydka, a piękno stanowi atrybut młodości - uwidaczniają się również w świadomości i wypowiedziach niektórych respondentek w wieku średnim i starych, gdyż gładka twarz i sprężysta, szczupła sylwetka niezależnie od wieku to wciąż przejaw pięknego, bo młodzieńczego, wyglądu zewnętrznego. Kobiety (częściej niż mężczyźni) reprezentujące dwie starsze kategorie wiekowe odnosiły autooceny wyglądu do swojej metryki, podkreślając przy tym urodę młodych kobiet:

Pewne walory już w pewnym wieku, atrakcyjne są głównie osoby w młodym wieku, młode kobiety, one są atrakcyjne. Natomiast już w pewnym wieku, to już (nie - przyp. aut.) (KSR_5_47). Byłam taką osobą, no, ja się nie wyróżniałam nigdy jakoś tak. No na pewno jako młoda wyglądałam lepiej, właśnie 
choćby z tytułu, że byłam szczupła bardzo długo. No lepiej się wtedy czułam na pewno i atrakcyjniejsza (KST_9_71).

Cytowane wyżej respondentki potwierdzają spostrzeżenie psycholog społecznej Alicji Głębockiej, iż „starsze kobiety internalizują negatywne stereotypy mówiące o tym, że stare nie jest piękne, co prowadzi do negatywnej ewaluacji własnego ciała" (Głębocka 2009: 80).

Biorąc pod uwagę odpowiedzi udzielone na pytanie o własną atrakcyjność przez badanych mężczyzn reprezentujących różne grupy wiekowe, można zaobserwować, że podobnie jak w przypadku zbiorowości kobiet, respondenci $\mathrm{z}$ najmłodszej kategorii wieku oceniali swoją powierzchowność najwyżej i tylko jeden młody badany wyraził się w tym przypadku jednoznacznie negatywnie: „Nie jestem zadowolony (ze swojego wyglądu - przyp. aut.). Szczerze mówiąc, to chyba [...] nic takiego nie mam (co mi się podoba - przyp. aut.)” (MM_9_30). Analogicznie do młodych kobiet wypowiedzi ich rówieśników uznających się za atrakcyjnych częściej były wyważone i niebezkrytyczne: „Raczej uważam się za atrakcyjnego mężczyznę” (MM_6_27), „Jestem zadowolony, natomiast brakuje trochę czasu, żeby trochę zadbać o sylwetkę" (MM_13_32).

$\mathrm{Z}$ kolei respondenci w wieku średnim, w odróżnieniu od mężczyzn młodych i starych, oceniali siebie najsurowiej, często przez pryzmat swoich wad i mankamentów wyglądu: „Raczej tak, chociaż mógłbym zmniejszyć brzuszek” (MSR_7_49); „Matka Natura poskąpiła mi wzrostu, prawda? Całe życie myślałem, że będę trochę wyższy, a skończyło się na 169 centymetrach" (MSR_8_53).

Starzy mężczyźni mieli największą trudność w formułowaniu autoocen wizerunku, a w swoich w głównej mierze neutralnych i pozytywnych stanowiskach względem własnego wyglądu zwrócili uwagę na aspekt akceptacji siebie: „Pozytywnie (oceniam swój wygląd - przyp. aut.). Akceptuję siebie” (MST_4_64); „Tu chodzi nie o mnie, bo ja się ze swoim wyglądem dobrze czuję" (MST_2_63).

Warto ponadto zauważyć, że wyłącznie w zbiorowości mężczyzn starych pojawiły się głosy, iż ocena ich atrakcyjności leży w gestii osób trzecich, a nie ich samych. Niektórzy respondenci z najstarszej kategorii wiekowej w pierwszej reakcji odżegnywali się od oceny własnego wyglądu, dystansując się tym samym do kwestii poddania siebie autokrytyce. Zdaniem tych badanych, aparycję mężczyzny oceniają/powinny oceniać kobiety: „A czy jestem atrakcyjny? To już żony proszę zapytać. Chyba normalny jestem. Ani piękny, ani brzydki. Zwyczajny” (MST_8_70). „Znaczy przyzwyczaiłem się może do siebie, tylko widzi pani, to jest taki problem, ja u siebie w lustrze nie widzę tego, co kobiety widzą. Może kobiety inaczej się patrzą" (MST_7_67). 
Nie bez znaczenia być może jest fakt, iż cytowani mężczyźni byli najdłużej poddawani patriarchalnej socjalizacji, w której uroda mężczyzny dla niego samego ma drugorzędne znaczenie i odgrywa rolę jedynie w relacjach interpersonalnych z osobami płci przeciwnej, w relacjach romantycznych, intymnych, gdzie istotna jest atrakcyjność seksualna.

Analizując opinie respondentów na temat ich wyglądu zewnętrznego z uwzględnieniem kategorii wieku, można wnioskować, iż ludzi młodych charakteryzuje najbardziej pozytywny stosunek do własnego wyglądu, czego dowodzi brak negatywnych autoocen wśród młodych kobiet i pojedyncze tego typu stanowisko w zbiorowości młodych mężczyzn. Natomiast wśród przedstawicieli badanych w średnim wieku oceny pozytywne pojawiają się wyraźnie rzadziej - zarówno kobiety, jak i mężczyźni w tej grupie wiekowej swoją atrakcyjność fizyczną oceniają bowiem najbardziej krytycznie:

(Oceniam się - przyp. aut.) negatywnie, bo mógłbym lepiej wyglądać [...]. Mógłbym być lepiej ubranym, bardziej zadbanym itd. (MSR_10_56). Nie, absolutnie, no nie, oceniam, nisko oceniam, bo jestem realistą, [...] realnie oceniam swoją twarz w lustrze. Nie poznaję siebie. Patrzę w lustro i mi się wydaje, że to jakiś tam, ktoś jest w lustrze, ale niespecjalnie podobny do mnie, ale to ja (MSR_11_57).

W świetle cytowanych powyżej wypowiedzi można zatem wnioskować, zgodnie z postawioną hipotezą, iż niezależnie od płci wraz z wiekiem respondenci nie tylko przykuwają mniej uwagi do swojej aparycji, ale i coraz gorzej oceniają własny wygląd zewnętrzny. Analizując rozkład opinii o własnej atrakcyjności w całej zbiorowości badanej, wyraźnie widać, iż najlepiej postrzegają siebie ludzie młodzi, a najmniej korzystnie ludzie w średnim wieku, a także w nieco mniejszym stopniu osoby stare. Warto jednak zauważyć, że w przypadku dwóch starszych kategorii wiekowych płeć różnicuje poglądy respondentów w tym zakresie. Ogółem kobiety w ocenie własnej aparycji są bardziej surowe w porównaniu do mężczyzn, a im są starsze, tym gorsze noty wystawiają swojemu wizerunkowi, gdyż negatywną opinię o własnym wyglądzie najczęściej prezentowały panie $\mathrm{z}$ najstarszej kategorii wiekowej, a nieco rzadziej kobiety w średnim wieku. W zbiorowości mężczyzn wyraźnie najgorzej oceniali siebie badani w średnim wieku, podczas gdy oceny respondentów z grupy starych były łagodniejsze.

Niemniej jednak starzy uczestnicy i uczestniczki badania częściej postrzegali swoją aparycję bardziej pozytywnie aniżeli ci w średnim wieku. Poziom zadowolenia z wyglądu zewnętrznego zwiększa się zatem wśród najstarszej grupy respondentów i respondentek powyżej 63 roku życia, o czym świadczą m.in. wypowiedzi: „Pozytywnie (oceniam swój 
wygląd - przyp. aut.). Akceptuję siebie” (MST_4_64). Też się uważam za atrakcyjnego (MST_10_71). Jeżeli chodzi o mój wygląd, to mogę powiedzieć, że jestem zadowolona [...]” (KST_5_67). „Nie mam żadnych kompleksów na temat swojego wyglądu i jak na swój wiek jestem bardzo zadowolona ze swojego wyglądu" (KST_2_64). Ludzie starzy (częściej mężczyźni), obserwując fizyczne zmiany w swoim ciele związane z upływem czasu, nierzadko przyjmują postawę akceptacji wobec nieuchronności starzenia się ciała człowieka postrzeganej jako naturalna kolei rzeczy. Jeśli dokonują subiektywnych porównań i ocen własnego wyglądu, to biorą pod uwagę swój wiek metrykalny i jego biologiczne, cielesne konsekwencje: „Znaczy przyzwyczaiłem się może do siebie [...] zawsze chodzi o to, żeby być i przystępnym i zadbanym” (MST_7_67); „Ja już się z tym (zmarszczkami - przyp. aut.) pogodziłem, to już jest wiek" (MST_12_72). Również badania psychologów społecznych przeprowadzone w Kanadzie na próbie mężczyzn między sześćdziesiątym a siedemdziesiątym rokiem życia pokazały, że panowie w podeszłym wieku są bardziej skłonni zaakceptować zmiany zachodzące w ich ciele aniżeli kobiety, a zmarszczki, siwiznę czy wzrost wagi przy obniżonym metabolizmie traktują jako naturalny skutek procesu starzenia się (Wiśniewska 2014).

Najczęściej jednak przedstawiciele dwóch najstarszych starszych grup wiekowych formułowali neutralne oceny własnej atrakcyjności. Respondenci w wieku średnim i starzy podkreślali swoją przeciętność, niewyróżnianie się, normalność, co odzwierciedla również ogólniejszy trend, iż wraz z wiekiem - zarówno w przypadku kobiet, jak i mężczyzn - maleje zainteresowanie własnym ciałem oraz słabiej odczuwany jest lęk związany $\mathrm{z}$ własnym wizerunkiem. U osób w średnim wieku i starszych obserwuje się bowiem „znacznie silniejszy związek między dobrostanem psychicznym a fizyczną sprawnością aniżeli między dobrostanem psychicznym a własnym wyglądem" (Głębocka, Kulbat 2005: 16).

\section{Czynniki wpływające na ocenę własnego wyglądu}

Respondentki i respondenci, oceniając swój wygląd zewnętrzny i własną atrakcyjność, odnosili się bezpośrednio lub pośrednio do różnych czynników. W uzasadnieniach tych subiektywnych autoocen najczęściej odwoływano się m.in. do: opinii innych ludzi lub porównania siebie $z$ innymi osobami, własnego samopoczucia, wieku i stanu zdrowia, a także posiadania lub nieposiadania kompleksów (w tym wskazywanie na mankamenty sylwetki) oraz działań na rzecz własnego wyglądu, dbałości o siebie. Powyższe kategorie czynników występowały w wypowiedziach osób badanych zarówno w ujęciu pozytywnym, jak i negatywnym, w zależności od formułowanej opinii na temat własnego wyglądu. 
Najczęściej wymienianą argumentacją, która miała wpływ na ocenę własnej atrakcyjności wśród przedstawicieli obu płci, była motywacja zewnętrzna, płynąca $z$ najbliższego środowiska: $z$ jednej strony powoływano się na opinie innych ludzi (członków rodziny, partnerów, przyjaciół, współpracowników), które kształtują jaźń odzwierciedloną jednostki; z drugiej strony zaś wiele uczestniczek i uczestników badania opierało swoje oceny na subiektywnym porównaniu siebie do innych osób. Czynniki te posłużyły do sformułowania tak pozytywnych, jak negatywnych stanowisk na temat własnego wyglądu. Kolejnym równie często przywoływanym argumentem przede wszystkim determinującym aprobatę kobiet i mężczyzn wobec ich wizerunku było dobre samopoczucie definiowane jako akceptacja siebie, sympatia dla siebie, brak kompleksów. Niektórzy respondenci odnieśli się także do wieku metrykalnego lub procesu starzenia się jako czynnika uzasadniającego korzystną bądź niekorzystną ocenę swojej atrakcyjności. Powyższe kategorie odpowiedzi okazały się być najpowszechniej przywoływane przez badanych $\mathrm{z}$ obu zbiorowości płci. Mimo ogólnych zbieżności w argumentacji przywoływanej na okoliczność autooceny własnego wyglądu daje się dostrzec różnice $\mathrm{w}$ sposobie formułowania stanowisk przez respondentki i respondentów. Ponadto kobiety w swoich odpowiedziach zdefiniowały szerszy katalog czynników wpływających na autoocenę wyglądu aniżeli mężczyźni. Dotyczy to zarówno odwoływania się do większej liczby kategorii uzasadniających, jak i większego zróżnicowania tych kategorii (np. wśród okoliczności wpływających na określoną ocenę wizerunku, mówiąc o zdrowiu i stylu życia, respondentki precyzowały poszczególne czynniki i wymieniały np. choroby, stres, niedostatek snu, kondycję fizyczną). Żaden z mężczyzn nie uwzględnił w uzasadnieniu oceny wyglądu zdrowia czy własnych wysiłków podejmowanych w celu poprawy wyglądu, które to czynniki pojawiały się w wypowiedziach badanych kobiet.

Analizując odwołania do pierwszej z powyższych zewnętrznych przesłanek oceny własnego wyglądu, najczęściej wskazywanych przez obie grupy płci badanych, tj. cudze opinie na własny temat - należy zauważyć, że w większości przypadków służyły one do uzasadnienia pozytywnych autoocen wyglądu zewnętrznego:

Jednak miałam parę sytuacji, że przekonałam się, że mogę być odbierana jako atrakcyjna kobieta przez innych zarówno przez mężczyzn, jak i przez kobiety. Miałam również sytuację, że zostałam uznana przez koleżankę jako zagrożenie, jeżeli chodzi o atrakcyjność (KM_2_24). Widzę się, że inni też na mnie patrzą i mówią »Elka, jak ty świetnie wyglądasz« (KSR_4_46). Jestem zadowolony z włosów na głowie. Zdaniem znajomych i rodziny są one gęste. 
Mi osobiście też się podobają, też z racji tego, że są często komplementowane właśnie (MM_3_22). Czuję się w swojej skórze dobrze. [...] dlatego chyba, że mam takie odczucie, że osoby wokół mnie, mnie akceptują takim, jakim jestem (MSR_8_53).

Opinia osób trzecich stanowiła również punkt odniesienia niezależnie od własnej oceny wyglądu (pozytywnej, neutralnej czy negatywnej), co obrazują poniższe wypowiedzi respondentów: „Tu chodzi nie o mnie, bo ja się ze swoim wyglądem dobrze czuję, tylko, że chodzi o innych, prawda.” (MST_2_63); „Dużo wpływa ocena innych, jak cię postrzegają i jak krytykują, co im się nie podoba” (KM_7_28).

Porównanie siebie do innych nieco częściej stanowiło podstawę subiektywnej autooceny własnego wizerunku w wypowiedziach kobiet niż mężczyzn i miało odmienny charakter w przypadku obu badanych zbiorowości płci. Respondentki przeważnie zestawiały swoją urodę z aparycją konkretnych osób: znajomych, koleżanek, a także sławnych osób:

Co zauważyłam, że podobają mi się też kobiety, jak gdzieś tam widzę w telewizji, jakieś celebrytki, które mają typ urody zbliżony do mojego, czyli znaczy to, że sama sobie się w miarę podobam, że akceptuję się na pewno, lubię swoją twarz (KSR_2_41). Wiesz, co myślę, że tak ogólnie ze wszystkiego jestem zadowolona. Na podstawie czego to mówię, porównuję się też z koleżankami w moim wieku tak? (KSR_3_42). Jak patrzę na koleżanki, to mi się mniej podobają niż ja sama sobie (KST_10_71).

Natomiast w wypowiedziach respondentów pojawiały się porównania mniej spersonalizowane, do bliżej nieokreślonego „ogółu innych”, jak w przypadku cytowanych dalej młodych mężczyzn: „(Jestem - przyp. aut.) niewyróżniający się za bardzo wyglądem spośród pozostałej [...] pozostałych osób, których można spotkać na ulicy” (MM_7_28). Kobiecość tradycyjnie silnie wiąże się z cielesnością, a kobieta - socjalizowana w poczuciu stałej kontroli własnego wyglądu i pielęgnacji urody - podporządkowuje się wymogom tego społecznego kanonu fizycznego piękna, chcąc uzyskać akceptację otoczenia (Kaschack 2001; Wolf 2014). Atrakcyjne ciało stanowi jeden z podstawowych elementów współczesnej koncepcji kobiecości (Wolf 2014), a wygląd zewnętrzny jako element kapitału ludzkiego kobiety, który w dużej mierze wpływa na jej pozycję społeczną, podlega ocenie i konkurencji (Berry 2008; Jakubowska 2009a). Jak bowiem zauważa A. Buczkowski, wartościowanie dokonuje się przede wszystkim „na podstawie wyglądu kobiety, a o wiele rzadziej na podstawie tego, kim jest i co mówi” (Buczkowski 2005:285). Stąd też prawdopodobnie wynika nie tylko silniejsza potrzeba i imperatyw dbania o wygląd zewnętrzny przez kobiety, ale również nawyk monitorowania i porównywania siebie $\mathrm{z}$ innymi przedstawicielkami płci pięknej. 
Akceptacja siebie i brak kompleksów to kolejny z czynników, który pojawił się w wypowiedziach na temat oceny własnej atrakcyjności w obu badanych zbiorowościach płci. Respondenci wspominali w tym przypadku, że „akceptują to, jak wyglądają”, „, dobrze się czują ze sobą" bądź „lubią siebie". Niemniej jednak daje się zaobserwować istotną różnicę w sposobie artykułowania omawianego czynnika przez kobiety i mężczyzn pozytywnie oceniających swój wygląd. Mężczyźni ograniczali się do nieemocjonalnego stwierdzenia, że akceptują swój wizerunek, jakim jest, przyjmując wygląd zewnętrzny jako swoisty zasób biologiczny. Nie uzasadniali ocen, niekiedy tylko odwoływali się dodatkowo do opinii innych osób. Kobiety natomiast przeważnie wyraźnie wzmacniały swoje stanowiska i wskazywały na konkretne subiektywne odczucie leżące u podstaw dodatniej samooceny: „Oceniam się jako osobę atrakcyjną fizycznie. Jestem zadowolona. Czuję się dobrze z tym, jak wyglądam” (KM_11_34). „Jeżeli atrakcyjność fizyczną można przyrównać do dobrego samopoczucia we własnej skórze, to powiedziałabym, że tak, czuję się atrakcyjna" (KM_2_24). „Ja się czuję atrakcyjnie” (KSR_3_42). Wypowiedzi mężczyzn charakteryzowała z kolei większa pewność osądu i bezwarunkowość: „Ale po prostu akceptuję siebie, takim jakim jestem” (MM_5_26). „Generalnie raczej chyba podoba mi się wszystko we mnie, nie specjalnie miałbym ochotę coś tam zmieniać" (MSR_1_38).

Na uwagę zasługują ponadto różnice w sposobie uzasadniania przez kobiety i mężczyzn oceny własnego wyglądu poprzez charakterystykę wad i niedoskonałości, a konkretnie mankamentów figury. Przedstawiciele obu płci odnosili się w swoich wypowiedziach do odbiegającego od modelowego kształtu sylwetki, a także przyznawali do nadwagi i otyłości. Jednakże podczas gdy mężczyźni jedynie wymieniali elementy budowy ciała, z których nie są zadowoleni (nieumięśniony lub obfity brzuch, „oponka”), kobiety dodatkowo wskazywały na działania podejmowane $\mathrm{w}$ celu przeciwdziałania niedoskonałościom w wyglądzie lub tłumaczyły się niejako ze swoich „zaniedbań” w tym względzie: „Wydaje mi się, że znam swoje wady i zalety i bardzo dużo przeciwdziałam, żeby zlikwidować te wady, czyli np. jak miałam troszeczkę problem z wagą, to starałam się to zredukować” (KM_9_30). „Chciałabym być szczuplejsza, co jest trudne. Nie jest niemożliwe, ale jest trudne" (KSR_5_47). Powyższe wypowiedzi świadczą ponadto o silnej internalizacji kulturowych wzorców kobiecości i propagowanego w mediach ideału kobiecego ciała. Model sylwetki obecny w różnych przekazach kulturowych wyraźnie wskazuje, że kobieta ma być szczupła, mieć proporcjonalną i zgrabną figurę, stąd silnie odczuwana przez żeńską część społeczeństwa presja troski o wygląd i dyskomfort posiadania obfitszych kształtów (Głębocka, Kulbat 2005; Głębocka 2009). Jak dowodzi w swoich 
badaniach cytowana już Alicja Głębocka, kult wąskiej talii przyczynił się do tego, że wyznacznikiem zadowolenia z wyglądu stała się niska masa ciała, a kobiety podejmują rozmaite działania, aby utrzymać sylwetkę w ryzach i obniżyć swoją wagę, do jakich należą najczęściej dieta i aktywność fizyczna (Głębocka 2009). Adekwatnie sukces w wysiłkach dla zachowania szczupłej figury stanowił mocny argument na rzecz wysokiej autooceny wyglądu respondentek: „w tej chwili, jeżeli chodzi o mój wygląd, to mogę powiedzieć, że jestem zadowolona w sensie takim, że udało mi się schudnąć 8 kilogramów i się dobrze czuję, lekko się czuję" (KST_5_67).

W odróżnieniu od mężczyzn kobiety w swoich wypowiedziach kładły również wyraźny nacisk na fakt dbania o siebie i starań podejmowanych w celu poprawy wyglądu, podczas gdy żaden mężczyzna nie wspomniał o tego typu czynniku, formułując ocenę własnej aparycji. Respondentki nie tylko deklarowały troskę o swój wygląd, ale również wymieniały konkretne działania przyczyniające się do lepszego samopoczucia i wpływające na pozytywną ocenę własnej atrakcyjności, m.in. codzienną pielęgnację skóry, uczesanie, manicure, makijaż, ubiór. Niewątpliwie liczne zabiegi pielęgnacyjne i upiększające, podejmowanie których deklarowały uczestniczki wywiadów swobodnych, istotnie i dodatnio wpływały na ich samoocenę:

Ja bym siebie opisała bardzo pozytywnie, bo tak jak mówię dbam o siebie, o codzienny swój wygląd, nie wyjdę nieuczesana na ulicę, muszę mieć zrobiony manicure, żeby te ręce były zadbane, żeby było widać, że się dba, więc określam się pozytywnie (KST_2_64). Ja na przykład jak sobie zrobię włosy, to fajnie, wszyscy widzą, że są fajne, a jak gdzieś się przemknę i są nieumyte albo spięte, to nie. Jak się ubiorę, że się spieszę i kurczę, no ubrałam się byle jak i pierwsze co na siebie włożyłam ok, i też się nie czuje wtedy dobrze (KSR_3_42).

Panie z najstarszych dwóch kategorii wiekowych w swoich ocenach wyglądu odwoływały się do wieku w powiązaniu ze zdrowiem i fizycznym samopoczuciem, czego nie odnaleziono w wypowiedziach młodszych respondentek ani w stanowiskach mężczyzn w podobnym wieku: „Jestem bardzo niezadowolona [...], bo się starzeję w szybkim tempie i właśnie zdrowie mi też odmawia posłuszeństwa” (KSR_10_56); „nie powiem tego, (że jestem atrakcyjna - przyp. aut.) bo, bo po prostu teraz coś czuję, że coraz słabiej” (KST_4_66). W przypadku starszych kobiet można zatem wnioskować za A. Głębocką, iż na subiektywną ocenę własnego wyglądu składa się nie tylko poziom satysfakcji z wizerunku ciała, ale również sprawność, kondycja fizyczna i ogólniej stan zdrowia jednostki (Głębocka 2009). 
Wśród czynników rzutujących na ocenę własnej atrakcyjności kobiety niezależnie od wieku wymieniały przede wszystkim opinie osób trzecich na swój temat, brak kompleksów i akceptację swojego wyglądu, a także porównywały siebie do innych osób, w szczególności kobiet z bliskiego otoczenia. W przypadku respondentek z najmłodszej kategorii wiekowej komplementy skierowane pod ich adresem były jednak argumentem najsilniej warunkującym samoocenę w odniesieniu do wyglądu zewnętrznego. Wizerunek młodych kobiet w ich oczach opierał się przede wszystkim na jaźni odzwierciedlonej, a kluczowe znaczenie miała w tym przypadku ocena partnera, członków rodziny czy przyjaciół. Należy przy tym podkreślić, iż były to zazwyczaj opinie pozytywne, jak np.: „Tak oceniam się (jako atrakcyjną - przyp. aut.), bo czasami mówią mi to koleżanki, koledzy i rodzina. Mówią mi, że ładnie wyglądam, a to daje mi pewności siebie" (KM_13_34).

Młode respondentki, formułując autooceny swojego wyglądu na podstawie porównywania siebie z innymi osobami, podkreślały swoją aktywność na rzecz dbania o ciało i prezencję:

Wydaję mi się, że (oceniłam siebie pozytywnie - przyp. aut.) przez to, jak wyglądają właściwie inne osoby w moim wieku. Niektóre albo w ogóle o siebie nie dbają i przez to w moich oczach przynajmniej wyglądają mniej atrakcyjnie, albo wykonują takie zabiegi, które mają właściwie odwrotny skutek i wyglądają przez to nieatrakcyjnie [...] często (stosuję różne zabiegi - przyp. aut.) i przez porównanie oceniam siebie i widzę, że inni nie stosują i są bardzie zaniedbani, nieatrakcyjni, niektórzy (KM_1_21).

O ile argument troski o własny wygląd i dokonywania zabiegów upiększających stanowił czynnik decydujący o pozytywnej samoocenie kobiet młodych i starych (KM_1_21; KM_3_24; KM_5_28; KST_ 2_64; KST_5_67), o tyle żadna z pań w średnim wieku nie powiązała własnej atrakcyjności z aktywnością na rzecz dbania o ciało. Wprost przeciwnie, pojedynczy głos w tym przypadku dotyczył negatywnej oceny własnego wyglądu i niepodejmowania działań pielęgnacyjnych: „Mam wrażenie, że jestem nie dość zadbana tak, czy nie dość wyspana. Nie dość tak jakoś nie wiem, nie dość często, no w ogóle nie chodzę do kosmetyczki czy coś takiego, a wiem, że moje koleżanki chodzą tak (KSR_5_47)".

Kobiety reprezentujące dwie starsze kategorie wiekowe rzadziej wymieniają cudze opinie jako czynnik wpływający na ich samoocenę, a jeśli już taki argument przytaczają, to częściej w negatywnym aspekcie. Brak pozytywnego wzmocnienia ze strony osób trzecich odbierają jako potwierdzenie swojej nieatrakcyjności lub przeciętności: „Wiesz, nie mogę powiedzieć, że jestem osobą atrakcyjną, bo nie wiem, jak mnie ludzie odbierają. Myślę, że nie (jestem atrakcyjna - przyp. aut.), bo nie budzę 
zainteresowania swoim wyglądem, a osoba atrakcyjna, to każdy się za nią obejrzy na ulicy. Za mną się nie oglądają na ulicy” (KST_7_7o). Z kolei komentarze innych osób, które wpływają na pozytywną samoocenę kobiet starych i wzmacniają ich zadowolenie $\mathrm{z}$ własnego wyglądu najczęściej związane są z młodym wyglądem mimo zaawansowanego metrykalnego wieku:

Nie wyglądam na swoje lata i bardzo wiele osób mi mówi, że mimo że w tej chwili mam 64 lata, to nikt nie określa mnie w takim przedziale wieku, tylko mówią, że wyglądam o wiele lepiej, czyli wyglądam gdzieś na 55 lat (KST_2_64). No nie wiem (jak oceniam wygląd - przyp. aut.), ale nikt mi nie daje prawie osiemdziesięciu lat! To jest fakt. Nikt mi nie wierzy, że mam już siedemdziesiąt prawie osiem (KST_11_77).

W przypadku kobiet z najstarszej kategorii wiekowej łagodny przebieg procesu starzenia się i młody jak na metrykę wygląd stanowił atut urody i podstawę pozytywnej samooceny nie tylko w świetle komplementów i miłych komunikatów z otoczenia, ale i w subiektywnych porównaniach respondentki z rówieśniczkami: „(osoby - przyp. aut.) w moim wieku też wyglądają nieraz starzej ode mnie” (KST_6_69); „Nie wiem, myślę, że porównuję się z rówieśnikami i uważam, że wyglądam całkiem ok, jak na mój wiek, porównywalnie" (KST_8_70).

Niektóre respondentki w średnim wieku i stare, w przeciwieństwie do kobiet należących do przedstawicielek najmłodszej grupy badanych zwróciły uwagę, że na ocenę ich wyglądu wpływają czynniki zewnętrzne, takie jak pora dnia czy styl życia (urlop i wypoczynek jako czynnik sprzyjający urodzie). Istotnym argumentem wpływającym na ocenę atrakcyjności wśród respondentek w średnim wieku i starych jest także stan zdrowia oraz nastrój czy kondycja psychiczna:

Niekiedy czuję się świetnie i wspaniale, właśnie tak, jak mówisz, czyli odlotowo. W momencie, kiedy jestem ubrana, jak ja chcę być ubrana, czuję się świetnie, nie mam żadnych problemów, dobrze wyglądam, czuję się wtedy atrakcyjna i mogę świat zawojować. Niekiedy czuję się kompletnie nieatrakcyjna, bardzo nawet nieatrakcyjna (KSR_11_6o). (Uważam się - przyp. aut.) za przeciętną [...], dlatego że nieraz mnie to boli, tamto boli, chodzę połamana, a to wpływa na samopoczucie i na wygląd (KST_12_84).

Ponadto, zgodnie z koncepcją „podwójnego standardu starzenia się” i rozważaniami psychologów społecznych na temat negatywnej percepcji starzejącego się ciała u starszych kobiet (Głębocka 2009, Wiśniewska 2014), niektóre spośród badanych w wieku średnim i starych oceniały swój wygląd negatywnie z perspektywy upływającego czasu i negatywnych zmian w fizjonomii: 
Są takie minusy, że widzę, że powieki mi się opuszczają, ale trudno. Patrzę w lustro, to widzę, że są zmiany. Jak oglądam fotografie, to widzę. Już się nie odwróci, to po co myśleć nad tym (KST_16_89). Niekiedy czuję się kompletnie nieatrakcyjna, bardzo nawet nieatrakcyjna. Kiedyś, troszeczkę lat ileś mniej, to te sygnały świadczyły o tym, że jestem osobą atrakcyjną (KSR_11_6o).

Analizując argumentację mężczyzn reprezentujących różne przedziały wiekowe, daje się zauważyć, że ich bardziej zwięzłe i oszczędne uzasadnienia były również słabiej zróżnicowane ze względu na kategorię wieku. Młodzi respondenci okazali się być najbardziej refleksyjni i z większą łatwością formułowali sądy na temat przedmiotu postawy aniżeli uczestnicy badania $\mathrm{z}$ dwóch starszych grup wiekowych. W swoich wypowiedziach młodzi respondenci najczęściej odwoływali się do pozytywnych opinii osób z najbliższego otoczenia, przede wszystkim kobiet, w tym partnerek, narzeczonych, żon, m.in.: „Czasami o tym rozmawiamy i ona (moja dziewczyna - przyp. aut.) daje sygnał, że jestem atrakcyjny, że nie mam co w sobie zmieniać. I po prostu podobam się jej.” (MM_4_24); „Narzeczona mówi mi, że mam bardzo ładne dłonie” (MM_6_27). Badani w średnim wieku brali przede wszystkim pod uwagę komplementy ze strony przyjaciół, członków rodziny czy współpracowników: „Mam duży nos i wąskie usta, ale ogólnie słyszałem nieraz, że mam ładną twarz, nie ładną, ale przystojną" (MSR_6_47). Rzadziej argumentem decydującym o atrakcyjności mężczyzny w średnim wieku był pochlebny komunikat od osoby płci przeciwnej: „Nawet te ostatnie 2-3 lata wręcz takie proste komplementy ze strony kobiet, np. potrafią powiedzieć, że jest bardzo piękny krawat, bardzo ładna koszula, że dopasowane są" (MSR_14_61). Brak pozytywnych ocen na podstawie informacji zwrotnych od kobiet w wypowiedziach najstarszych respondentów prawdopodobnie świadczy o mniejszej aktywności starszych ludzi w kontaktach romantycznych i intymnych, które są intensywniejsze na wcześniejszych etapach życia człowieka, kiedy poszukuje się partnera i zawiązuje relacje intymne.

Sięgając po argument porównania siebie z innymi ludźmi, najczęściej w podobnym wieku, w autoocenie wyglądu zewnętrznego młodzi mężczyźni skupiali się na atrybutach fizycznych, jak budowa ciała i kształt sylwetki:

Tak jak powiedziałem, ze względu na porównanie z kolegami i innymi. Porównując kolegów do siebie, to wydaje mi się, że jestem zdecydowanie bardziej atrakcyjny niż inni. [...] Chociaż patrząc z takiej perspektywy, że moi koledzy niestety utyli troszeczkę, to ja nie mam takich kompleksów. Nie mam takich problemów, typu: ściągam koszulkę i wisi mi sadło, tylko ściągam koszulkę i wyglądam normalnie, więc to przemawia za tym, że jestem atrakcyjny (MM_4_24). 
Natomiast w wypowiedziach mężczyzn w średnim wieku i starych często nie sam wygląd zewnętrzny i cechy ciała odgrywały istotną rolę, a wygląd i kondycja ciała w powiązaniu wiekiem:

Nie mnie to oceniać, ale widzę w pracy, mam porównanie, że młody dwudziestolatek, który przychodzi do nas do pracy, nie zrobi wielu tych rzeczy, które zrobię ja (MSR_2_39). To, co wcześniej powiedziałem, to, że wyglądam młodziej od swoich rówieśników (MSR_6_47). Niektórzy nie mówią, że mam tyle lat. Liczą mi mniej lat, ale ja zniszczony jestem, wiem sam po sobie (MST_14_82). Jak byłem młodszy to tak, człowiek szpanował, a teraz nie ma już czym szpanować (MST_12_72).

W świetle powyższych wypowiedzi daje się zaobserwować, iż odwołania do metryki w przypadku mężczyzn w średnim wieku mają charakter pozytywny i wpływają na wysoką ocenę własnej atrakcyjności, mimo świadomości upływu czasu. W przypadku mężczyzn starych z kolei zaawansowany wiek i towarzyszące mu zmiany fizjologiczne rzutują na autoocenę wyglądu w sposób pejoratywny z racji biologicznych zmian organizmu człowieka i rosnących ograniczeń ciała.

Warto ponadto zwrócić uwagę na brak odniesień do czynników zdrowotnych i pielęgnacyjnych w wypowiedziach mężczyzn reprezentujących wszystkie kategorie wiekowe. Jedynie jeden z badanych w średnim wieku odniósł się do możliwości podjęcia pewnych wysiłków w celu poprawy swojego wyglądu: „(Oceniam się - przyp. aut.) negatywnie, bo mógłbym lepiej wyglądać. [...] myślę, że jest wiele rzeczy. Mógłbym być lepiej ubranym, bardziej zadbanym itd. To zawsze jest kompromis między możliwościami a chęcią może" (MSR_10_56). Brak tego typu refleksji prawdopodobnie wynika z socjalizacji zgodnej z patriarchalną koncepcją męskości, w myśl której troska o kondycję i wizerunek własnego ciała nie leży w gestii mężczyzny, o którego w tym zakresie tradycyjnie dba kobieta: matka, partnerka, żona.

Z kolei rozważając wypowiedzi uczestników wywiadów swobodnych wyłącznie $\mathrm{z}$ uwzględnieniem kategorii wieku, daje się zaobserwować dwie zasadnicze różnice $\mathrm{w}$ formułowaniu emocjonalnych ocen wobec przedmiotu postawy. Młodzi ludzie - zarówno kobiety, jak i mężczyźni - wyraźnie najczęściej w swoich opiniach na temat własnego wyglądu zewnętrznego oglądają się na innych ludzi i poszukują ich aprobaty. Wraz z wiekiem tendencja do opierania sądów na temat własnej aparycji na motywacji zewnętrznej maleje na rzecz czynników wewnętrznych, często związanych z postępującym wiekiem biologicznym i towarzyszącymi mu zmianami w ciele człowieka. Co więcej, respondenci i respondentki z najmłodszej grupy wiekowej, poszukując pozytywnego wzmocnienia dla oceny własnej powierzchowności u osób z otoczenia, 
przede wszystkim oczekują informacji zwrotnej od przedstawicieli płci przeciwnej, w tym swoich parterów: „Mogę powiedzieć, że tak. Zarówno chłopak, jak i otoczenie wskazuje, że jestem atrakcyjna. W sumie też tak uważam” (KM_1_21). „Mojej żonie się podoba, że lepiej wyglądam, także jestem atrakcyjny nie tylko dla niej, ale i dla innych, że jestem fajny, wśród koleżanek, wśród znajomych może się pochwalić, że ma takiego męża” (MM_10_31). Jak zasygnalizowano wcześniej w tym podrozdziale, ma to zapewne związek $\mathrm{z}$ większą intensywności kontaktów o charakterze intymnym i romantycznym na tym etapie życia i silniejszą potrzebą bycia atrakcyjnym i pożądanym na rynku matrymonialnym.

Respondenci i respondentki w wieku średnim i starzy w swoich wypowiedziach odwoływali się przede wszystkim do swojej metryki i wymieniali młodzieńczy wygląd lub proces starzenia się jako czynniki rzutujące na wygląd i atrakcyjność. W wielu przypadkach obserwacja zmian twarzy i ciała wraz z upływającym wiekiem wpływała na negatywną percepcję własnej powierzchowności tak wśród kobiet, jak mężczyzn. Niemniej jednak nierzadko metryka stanowiła punkt odniesienia również w ocenie atrakcyjnego, akceptowanego, młodego (jak na biologiczny wiek) wyglą$\mathrm{du}$, co znajduje swoje odzwierciedlenie także w wypowiedziach najstarszych respondentów niezależnie od kategorii płci:

Ja się nie oceniam jako atrakcyjny i nieatrakcyjny w porównaniu z panami w moim wieku, którzy - pomijam sprawy włosów, bo to jest rzecz genów - ale jak widzę człowieka o sylwetce jakiejś sprężystej wysportowanej i obok niego idzie taki dwa razy cięższy z brzuchem $150 \mathrm{w}$ pasie no to jasne, że się oceniam bliżej tego pierwszego niż tego drugiego (MST_11_77). Nie mam żadnych kompleksów na temat swojego wyglądu i jak na swój wiek jestem bardzo zadowolona ze swojego wyglądu (KST_2_64).

Analiza wypowiedzi respondentek i respondentów w różnym wieku na temat czynników wpływających na ich subiektywną ocenę własnego wyglądu potwierdza wnioski płynące z dyskusji na temat samych autoocen wizerunku (por. podrozdz. 3.2.1) w odniesieniu do hipotezy ogólnej, zgodnie z którą kobiety, niezależnie od wieku, są surowsze i bardziej krytyczne względem omawianego przedmiotu postawy. Wielość argumentów, jakimi posłużyły się badane dla uzasadnienia (nawet pozytywnej aczkolwiek umiarkowanej) opinii o swojej powierzchowności, dowodzi, iż dla kobiet wygląd ma istotne znaczenie, a jego pozytywna ocena jest mocno uwarunkowana i zależy od wielu czynników zewnętrznych (opinia innych ludzi, wiek biologiczny, pora dnia) i wewnętrznych (stan zdrowia, kondycja fizyczna, samopoczucie, styl życia, zabiegi pielęgnacyjne). Respondentki częściej niż respondenci, formułując autooceny swojego wyglądu, uciekały się do porównań siebie z innymi kobietami, najczęściej 
w podobnym wieku, a także do podejmowanych przez siebie licznych zabiegów pielęgnacyjnych. Większe znaczenie $\mathrm{w}$ wypowiedziach badanych kobiet dla krytycznej oceny własnej atrakcyjności miał ponadto kształt sylwetki. Mężczyźni rzadziej i z większym trudem motywowali swoje stanowiska, najczęściej kierując się komplementami osób z otoczenia lub własnym dobrym samopoczuciem, akceptacją siebie.

Jeśli chodzi o kategorie wiekowe, ponieważ współcześnie kulturowa koncepcja młodości pomniejsza istotę kulturowych definicji płci, płeć słabo dywersyfikuje postawy młodych ludzi. Dla młodych uczestniczek i uczestników badania, którzy najwyżej ocenili własną powierzchowność i zdecydowanie częściej postrzegali siebie jako atrakcyjnych fizycznie, najważniejszym czynnikiem autooceny okazały się bowiem opinie osób $\mathrm{z}$ zewnątrz oraz porównanie siebie na tle rówieśników. Badani $\mathrm{w}$ wieku średnim i starzy zdecydowanie rzadziej szukali uzasadnienia dla oceny własnego wizerunku w oczach innych ludzi, a w ich wypowiedziach sukcesywnie pojawiały się odwołania do metryki. Istotnym czynnikiem wpływającym na neutralną i pozytywną opinię na temat wyglądu kobiet i mężczyzn z dwóch najstarszych kategorii wiekowych miało ponadto samopoczucie, rozumiane jako akceptacja siebie i w przypadku starszych badanych oznaczało brak wygórowanych wymagań względem swojej cielesności lub pogodzenie się z biologicznymi zmianami starzejącego się ciała.

\subsection{Komponent behawioralny}

\subsubsection{Płeć kulturowa i uptciowiony wiek a dziatania korzystnie wpływające na wygląd (Ewa Malinowska)}

W niniejszym rozdziale zajmiemy się sposobami troszczenia się o swą fizyczną atrakcyjność opisywanymi przez respondentów, a dokładniej - dbaniem o ubiór i ciało przez kobiety i mężczyzn należących do trzech kategorii wieku: młodych, w średnim wieku i starych. Jeśli chodzi o ostatnią z wymienionych kategorii wieku, wykorzystane tu zostaną częściowo wyniki autorskiej, rozszerzonej analizy sposobu dbania o wygląd przez stare kobiety i starych mężczyzn opublikowane w 2016 roku (Malinowska 2016).

Wychodząc od twierdzeń sformułowanych w ramach hipotezy pierwszej, dążymy do udzielenia odpowiedzi na następujące pytania: czy 
podobieństwa dotyczące sposobu dbania o wygląd przez kobiety i mężczyzn reprezentujących trzy kategorie wiekowe uwidaczniały się głównie w obrębie danej kategorii wieku, np. między ludźmi młodymi bez względu na płeć, a różnice - między kategoriami płci, tj. między kobietami a mężczyznami bez względu na wiek? Czy zróżnicowania genderowe działań korzystnie wpływających na wygląd wystąpiły głównie wśród ludzi starych?

\subsubsection{Dbanie o swój wygląd przez kobiety i mężczyzn a wiek}

Spośród respondentów należących do pokolenia ludzi młodych niemal wszyscy przywiązywali do stroju dużą wagę. Zgodnie podkreślano znaczenie posiadania i kultywowania własnego stylu ubierania, kierowanie się przy kupowaniu ubrań głównie ich wygodą oraz ubieranie się stosownie do sytuacji.

Jeśli chodzi o sposób ubierania się, młodzi ludzie, bez względu na płeć, preferowali styl sportowy: „Raczej ubrana w spodnie - niebieskie dżinsy, jakaś bawełniana bluzeczka - musi być wygodna - czarna, biała, kolorowa i na czasie, buty baleriny lub jakieś szpilki, ale wolę baleriny bo są wygodniejsze. [...] Raczej lubię luźny i wygodny styl ubierania się" (KM_13_34). Niektórzy młodzi mężczyźni i niektóre młode kobiety przy tej okazji podkreślali funkcjonalność i łatwość realizowania stylu sportowego na co dzień:

Nie jestem osobą, która dąży za modą non stop, dlatego styl (sportowy - przyp. aut.) mi podpasował, luźno dobrze czuję się, nie jestem tak jakby zamknięty w sobie w tym ubraniu, czuję się bardziej taki luźny i dostępny dla innych. I tyle (MM_8_29); Chcę w ubiorze móc wykonywać swobodne ruchy bez obawy, że mi coś wyjdzie na wierzch, ale również nie chcę, aby mnie ubiór gryzł lub obcierał (KM_2_24).

Najważniejszym i także wspólnym kryterium wyboru ubrań stosowanym przez ludzi młodych okazała się wygoda: „[...] bardzo często lubię ubierać się luźno. Przede wszystkim stawiam na wygodę, żeby mi było wygodnie. Nie kupię butów na obcasie, które miałyby mnie upijać, [...]. Najważniejsza dla mnie jest wygoda [...]" (KM_2_24). Spośród wszystkich respondentów współtworzących kategorię ludzi młodych tylko kobieta uzasadniła preferowanie wygody w sposobie ubierania, wykonywaniem obowiązków wynikających z roli rodzicielskiej: „Wygodnie. Teraz szczególnie przy dzieciach ubieram się wygodnie, chyba że mam okazję wyjść bez dzieci, to wtedy się ubieram niewygodnie - z premedytacją" (KM_14_35). Z kolei tylko niektórzy młodzi mężczyźni (młode kobiety - nie) zdecydowanie podkreślali kierowanie się własnym gustem 
oraz zdecydowanie przedkładali wygodę ubrania nad jego walory estetyczne: „[...] dla mnie najważniejsza jest wygoda. Atrakcyjność jest rzeczą [...] drugoplanową. Jak powiedziałem, ja się nie wyróżniam z tłumu i nie chcę się wyróżniać z tłumu [...], mam mieć wygodne buty, rzeczy, w których się dobrze czuję" (MM_5_26).

Jeśli ubieranie się stosownie do okazji uznać za definicję elegancji, młodzi ludzie obojga płci będący naszymi respondentami zdecydowanie mogliby uchodzić za takie właśnie osoby. „Ubierać się odpowiednio do sytuacji" - była to bowiem druga zasada, hołdowanie której młode kobiety i młodzi mężczyźni deklarowali najczęściej. Młodzi „swobodnie” ubierają się tylko w domu:

[...] jeśli sama siedzę w domu, to nie obchodzi mnie jak wyglądam wtedy. W domu lubię czuć się swobodnie, jakiś wyciągnięty dresik, kucyk lub takie coś na głowie (KM_3_24). Wychodząc w jakiekolwiek miejsce publiczne, staram się wyglądać elegancko i adekwatnie do miejsca, w które się wybieram. Zazwyczaj noszę koszulę, [...] wychodząc z domu, nigdy nie ubieram się w dresowe ciuchy (MM_4_24). Myślę, że (strój - przyp. aut.) powinien być odpowiedni do okazji, do miejsca, w które się wybieram. Można ubiorem podkreślić swojąa atrakcyjność (MM_6_27).

Inni młodzi respondenci - kobiety i mężczyźni - akcentowali nie tyle konieczność dostosowania ubioru do typu przestrzeni, co do rodzaju wydarzenia:

No, to zależy też od okazji, od tego, czy ubieram się na co dzień, czy gdzieś muszę wyjść, gdzieś bardziej oficjalnie czy na jakąś imprezę. [...] zaczynając od, powiedzmy, wyjściowej koszuli, ciemnych spodni, bardziej eleganckich butów, dochodząc do [...] garnituru, który jest takim symbolem eleganckiego ubioru męskiego (MM_1_21). [...] gdy mam wyjść gdzieś na miasto czy do urzędu coś załatwić, to staram się ubrać stosownie do sytuacji, czyli dłuższe spodnie, buty wyjściowe, jakaś koszula, kurtka. Do pracy - wyjściowo, musi być jakiś dress code zachowany (MM_14_35).

Młode kobiety i młodzi mężczyźni zapewniali także, iż dbają o kolorystykę ubioru, głównie zwracając uwagę na właściwy dobór barw; dla nielicznych miała znaczenie również jakość odzieży i wysokość cen ubrań. W tym ostatnim przypadku stawiali jednak na jakość, a nie na niższą cenę:

Bardziej patrzę na to, jak to ubranie wygląda, [...] jakiej jakości jest materiał, czy nie zrobi mi się z tego szmata po dwóch praniach (MM_1_21). No cena też ma znaczenie, ale nie jest to główny czynnik, to znaczy wolę sobie nawet trochę odłożyć i poczekać, i kupić coś, co jest droższe, ale będzie lepszej jakości, 
będę to miała dłużej i będzie na przykład, nie wiem, lepiej uszyte, będzie mi w tym wygodniej (KM_12_34).

Z perspektywy genderowej warta zauważenia jest wypowiedź trzydziestosześcioletniej respondentki, a więc kobiety będącej w momencie udzielania wywiadu relatywnie blisko dolnej granicy wieku średniego (tj. 38 lat), gdyż o poruszonym przez nią problemie nie wspomniał żaden $z$ jej rówieśników.: „Ja się odmładzam np. strojem. Zauważyłam że po trzydziestce zaczęłam nosić krótsze spódniczki, no może bez przesady, ale zaczęłam nosić sukienki [...]” (KM_15_36). Być może presja panującego współcześnie kultu młodości i piękna, nie była jeszcze tak odczuwalna dla naszych respondentów jak dla respondentek, zwłaszcza że właściwy patriarchalnej kulturze charakter procesu socjalizacji powoduje, iż u dziewcząt od początku wyrabia się psychospołeczne dyspozycje do ustawicznego działania na rzecz zachowania młodości i urody. Specyfika sytuacji kobiet polega jednak nie tylko na zinternalizowaniu kulturowej koncepcji „płci pięknej”, czemu młode respondentki dawały wyraz w wywiadach, ale na równoczesnym ich dążeniu do osiągnięcia sukcesu życiowego definiowanego przez młode pokolenie androgynicznie (w przeciwieństwie do pojmowanego tradycyjnie, tzn. w przypadku kobiet utożsamianego wyłącznie z udanym zamążpójściem i macierzyństwem). W przypadku ludzi młodych, mających, jak nasi rozmówcy, wykształcenie średnie lub wyższe, sukces ten jest bowiem związany zdecydowanie i w przypadku obu płci z karierą zawodową. Tę realizuje się w warunkach konkurencji, zarówno na rynku pracy, jak i na zmienionym dziś rynku matrymonialnym, gdzie, przynajmniej formalnie upodmiotowione społecznie kobiety (samodzielne ekonomicznie, mające te same prawa co mężczyźni), dokonując wyboru partnera życiowego, w stosunku do mężczyzn stosują m.in. kryterium młodego, zadbanego wyglądu. Dowodzą tego m.in. badania polskich (i nie tylko polskich) singielek (Czernecka 2011). Z kolei specyfika sytuacji młodych mężczyzn, w porównaniu z ich rówieśnicami, a zwłaszcza z pokoleniem starszych mężczyzn, polega na włączeniu obecnie cech wyglądu do modelu męskości i na ogromnym wzroście znaczenia aparycji dla społecznego funkcjonowania także płci „niepięknej” (czego respondenci okazali się świadomi). Na rynku pracy młodzi mężczyźni muszą konkurować z kobietami, a na rynku matrymonialnym podporządkować się nowym regułom jego funkcjonowania, tj. pełnić tam również bierną, uprzedmiotowioną rolę wybieranego, a nie wyłącznie podmiotu dokonującego wyboru.

Dbanie o wygląd to również dbanie o ciało. Podobieństwo zachowań młodych kobiet i młodych mężczyzn dotyczyło nie tylko podstawowego zakresu tych starań, czyli dbania o higienę osobistą i o fryzurę (panowie 
głównie o strzyżenie, a panie o staranne jej modelowanie oraz o zdrowie i urodę włosów). Wśród młodych ludzi nawet nakładanie maseczki kosmetycznej na twarz przestało być jedynie kobiecym zabiegiem; manicure też nie jest czynnością praktykowaną wyłącznie przez kobiety, podobnie jak peeling - wymieniany przez młodych płci obojga. Repertuar zachowań związanych z dbaniem o atrakcyjny wygląd ciała okazał się więc zaskakująco podobny. Podobnie zresztą jak rodzaj i przeznaczenie stosowanych kosmetyków. Na przykład młodzi mężczyźni wspominali także o używaniu kosmetyków specjalistycznych oraz perfum, nie tylko wody po goleniu czy dezodorantu. Co ciekawe, niektórzy młodzi respondenci podkreślali szczególną rolę kobiet we wdrażaniu ich do tego rodzaju zachowań. Nie mówili jednak o zasługach kobiet starszego pokolenia, tzn. matek ani o ich socjalizacyjnych wysiłkach, lecz o roli żon, partnerek, a więc kobiet $\mathrm{z}$ tego samego pokolenia, którym mają się podobać i które same doceniają znaczenie zadbanego wyglądu dla społecznego funkcjonowania człowieka. Wspólne dla młodych kobiet i mężczyzn było także niemyślenie o zabiegach z zakresu medycyny estetycznej.

Obrazy aktywności fizycznej młodych kobiet i mężczyzn nie były natomiast już tak podobne. Młodzi mężczyźni chętnie deklarowali czynny udział w różnorodnych formach takiej aktywności, jednak dwie trzecie uzupełniało swe wypowiedzi jakimś zastrzeżeniem:

Jeszcze niedawno, [...] ćwiczyłem [...]. W ostatnim czasie to porzuciłem [...]. Mam ostatnio bardzo dużo obowiązków i nie mam za bardzo na to czasu [...] (MM_6_27). No tak, jeszcze czasami chodzę na ściankę, ale dawno nie byłem [...] (MM_5_26). Szczerze powiem, że obecnie trochę zaniedbałem różnego rodzaju sporty, trochę to wynika z moich kontuzji (MM_15_37).

Młode kobiety, przynajmniej w świetle deklaracji naszych rozmówczyń, okazały się natomiast bardziej sumienne w ćwiczeniu, a wymieniały wiele typów aktywności. Wśród nich najpopularniejsze było pływanie, gimnastyka, spacery, ale także taniec i tzw. męski sport walki - boks. Biorąc pod uwagę, że badani nie należeli do „młodzieży”, lecz byli młodymi ludźmi w wieku 20-37 lat, wpływ na omawiane zachowania mogła mieć ich aktywność zawodowa, rodzinna, a więc istnienie tego rodzaju przeszkód w uprawianiu regularnej aktywności sportowo-rekreacyjnej. W takim kontekście należałoby więc zapytać o realizowany przez respondentki i respondentów wzór płciowego podziału ról społecznych (w pracy i w domu) (Dzwonkowska-Godula 2015), a także o doświadczenia dotyczące zróżnicowanej płciowo socjalizacji i na przykład o wdrażanie dziewcząt do obowiązkowości i pilności w realizacji wszelkich zobowiązań (także tych podjętych wobec siebie, jak uprawianie sportu), co stanowi rdzeń tzw. syndromu dobrej uczennicy. 
Wydaje się, że w sposobie dbania o ciało można dostrzec tendencję do feminizacji zachowań młodych mężczyzn. Jest to empirycznie stwierdzony przejaw częściowej modyfikacji patriarchalnej definicji męskości (dotyczy jednego elementu z kulturowego modelu męskości, tzn. wyglądu), polegającej na uwzględnieniu kulturowo postmodernistycznego sposobu definiowania młodości.

Osoby w średnim wieku natomiast, bez względu na płeć, w dbaniu o ubiór trzymały się głównie jednej zasady: dobierać strój stosownie do okazji. Intersująca różnica jakościowa dotyczyła tego, że kobiety będące $\mathrm{w}$ średnim wieku częściej niż ich rówieśnicy stawiały na wygodę ubrań, a mężczyźni głównie mieli na względzie swą dobrą prezencję, ale i samopoczucie. Ubierali się, ich zdaniem, stosownie, oryginalnie i stylowo: „Ubiór musi być stosowny do danej chwili. Czy wyjście na miasto z kolegami - można się ubrać luźniej; [...] powinien się człowiek tak ubierać, żeby czuć się dobrze” (MSR_2_39); „Więc dla mnie idealny jest taki ciuch na pograniczu elegancji i casualu, w tym czuję się absolutnie najlepiej” (MSR_1_38). Ponieważ tylko niektóre kobiety z tej kategorii wieku (mężczyźni - nie) wspomniały o „ubieraniu zgodnie z wiekiem”, można przypuszczać, że sportowym i „luźnym”, wygodnym sposobem ubierania starały się ułatwiać sobie i innym, identyfikowanie ich nadal z ludźmi młodymi.

Mężczyźni w średnim wieku równie często jak ubieranie się stosowne do okazji wymieniali kierowanie się własnym gustem i posiadanie własnego stylu. Kobiety natomiast równie często jak ubieranie się odpowiednio do okazji akcentowały wspomnianą już wygodę stroju oraz właściwy dobór kolorów. W tym kontekście właśnie wśród kobiet w średnim wieku pojawiły się wyraźne obawy przed rozpoznawalnymi oznakami starzenia się. Kolorem starały się bowiem korygować na przykład zauważone niedoskonałości cery oraz podkreślały to, co warto zaakcentować, jak na przykład typ swej urody. Niektóre respondentki odwoływały się nawet do psychologii barw: „W tej chwili są mi bardziej potrzebne kolory energetyczne, w których się lepiej czuję [...], czyli jakiś [...] zielony, pomarańczowy, żółty, wszystko jedno, a im bliżej wiosny, tym bardziej” (KST_11_6o). Mężczyźni w średnim wieku (a jak się okazało, także starzy) preferowali natomiast spokojne kolory ubrań: „Lubię takie kolory niebiesko-granatowo-czarne, one dominują" (MSR_3_40).

W patriarchalnej kulturze społeczne znaczenie procesu starzenia się jest zróżnicowane płciowo: mężczyźni w średnim wieku nie obawiają się jeszcze starości, a kobiety - tak. Starzejąc się, mężczyźni nie tracą pewności siebie, a jeśli osiągnęli satysfakcjonujące ich pozycje społeczne, właśnie w tym okresie życia mają wysokie poczucie własnej wartości i w pełni realizują swą podmiotowość. Jednym z jej przejawów, wcale nie mało 
znaczącym, jest kierowanie się w sposobie ubierania własnym gustem i stylem. Wydaje się, że polscy mężczyźni będący obecnie w średnim wie$\mathrm{ku}$, są ostatnim pokoleniem nieocenianym jeszcze po wyglądzie $\mathrm{w}$ takim stopniu, jak dotyczy to ich rówieśnic oraz mężczyzn młodszego pokolenia. Na razie więc wejście w wiek średni uwalnia ich od niemęskiej kulturowo presji podobania się innym, chyba że w międzyczasie zinternalizowali atrakcyjny wygląd jako wartość autoteliczną, a dbanie o aparycję uczynili zasadą dotyczącą życia codziennego. Tego akurat nasi rozmówcy nie deklarowali.

Wśród osób w wieku średnim widać więc przejawy patriarchalnej genderyzacji zachowań dotyczących dbania o ubiór, zwłaszcza w porównaniu $\mathrm{z}$ androgynicznym głównie charakterem zachowań ludzi młodych. Na marginesie warto też zauważyć, że wśród badanych w wieku średnim tylko jedna kobieta i jeden mężczyzna wspomnieli o wysiłkach podejmowanych w celu tuszowania odpowiednim strojem mankamentów swej sylwetki.

Kobiety i mężczyźni ze wszystkich kategorii wieku, a więc także reprezentujący wiek średni, zwracali uwagę na schludność ubioru. Nie ustalano, czy mężczyźni te starania podejmują sami, czy też o stan męskiej odzieży, zgodnie z patriarchalnymi nawykami, dbają głównie kobiety. Gdyby odwołać się tu do wyników potocznych obserwacji, uzasadniona wydaje się hipoteza, iż najmniej samodzielni są pod tym względem mężczyźni starzy.

Jeśli chodzi natomiast o zachowania dotyczące dbania o ciało, z wypowiedzi respondentów wynika, że osoby w średnim wieku zachowują pewien podstawowy standard: codzienna kąpiel/prysznic, mycie zębów, mężczyźni - golenie się, kobiety - makijaż. Tylko kobiety tuszują mankamenty urody. Czynności tego typu jak stosowanie maseczki kosmetycznej na twarz - należące kulturowo do repertuaru kobiecego, wykonywały tylko panie; jednak inne zabiegi, jak peeling, manicure i pedicure robią także mężczyźni ze średniego pokolenia, najchętniej samodzielnie, $\mathrm{w}$ domu. Osoby w średnim wieku obu płci korzystają ponadto z wizyt w gabinecie kosmetycznym, ale nawet kobiety niezmiernie rzadko, a jedyny spośród respondentów - za namową żony:. „Od czasu do czasu żona mnie nakłoni. Chociaż ja jestem wstrzemięźliwy do kosmetyczki, dam sobie zrobić manicure" (MSR_8_53).

Jeśli chodzi o dbanie o ciało, w średnim pokoleniu obserwowalna była swoista naturalność zachowań tego typu u kobiet, zwykle od dzieciństwa wdrażanych do takiego działania. Wypowiedzi mężczyzn potwierdzają jednak, że czerpiąc od kobiet inspirację, a nierzadko mając w tym zakresie ich pomoc, sami przyzwyczajają się stopniowo do „ponadnormatywnych” w porównaniu z typowo męskimi, standardów zachowań: „Czasem 
zdarzało mi się używać kremu pod oczy, kiedy jestem mocno zaspany, ale to też nauczyłem się tego od kobiet" (MSR_1_38). Genderowe zróżnicowanie zachowań można było zaobserwować w przypadku aktywności sportowo-rekreacyjnej badanych. Kobiety deklarowały głównie wykonywanie regularnych ćwiczeń gimnastycznych (połowa z nich chodzi na zajęcia typu joga, fitness), jeżdżą na rowerze. Mężczyźni - korzystanie z siłowni i basenu, ale raczej niezbyt regularnie; czasem deklarowali, iż ćwiczą w domu, na działce, czyli od weekendu do weekendu.

Kolejnym przejawem feminizacji zachowań mężczyzn w średnim wie$\mathrm{ku}, \mathrm{w}$ porównaniu z patriarchalnym modelem męskości, jest rozszerzenie gamy stosowanych kosmetyków. To już nie tylko woda po goleniu, dezodoranty czy klasyczne, męskie perfumy; używali także specjalistycznych kremów, pianek i balsamów.

Podobnie jak było to w przypadku osób młodych i będących w średnim wieku, również wypowiedzi osób starych opisywały dbanie o ubiór i o ciało. Wszyscy deklarowali, że o swój wygląd dbają. Okazało się także, iż w tej kategorii wieku stopień i zakres zaabsorbowania własnym wyglądem był większy w przypadku kobiet niż mężczyzn (por. Malinowska 2016). Paradoks sytuacji, w której znajdują się stare kobiety, polega na tym, że nawet ich zadbany wygląd na ogół nie obchodzi rówieśników (a jest to w zasadzie jedyna zbiorowość mężczyzn - potencjalnych partnerów dla kobiet w tym wieku). W patriarchalnej kulturze utożsamiającej atrakcyjność kobiety z młodością, urodą i zdolnością do rozrodczości, mężczyzn nie interesują jednak stare kobiety, a więc nie interesuje ich wygląd starych kobiet (Malinowska 2011). Kobiety zresztą wiedzą, że osiągnąwszy „pewien wiek” stają się „przezroczyste”. Z tych samych względów kulturowych starzy mężczyźni natomiast nie odczuwali w młodości ani nie odczuwają teraz porównywalnej presji społecznej co do zachowania atrakcyjnego wyglądu. W ich pokoleniu szczególna dbałość o aparycję jest zresztą uważana stale za „niemęską".

Jeśli chodzi o hierarchię ważności kryteriów stosowanych przy wyborze ubrań, w zbiorowości trzeciego wieku była ona także wyraźnie zróżnicowana według płci. I tak na przykład dla starych mężczyzn jednym z najważniejszych kryteriów była „wygoda”. Patriarchalna kultura z definicji skoncentrowana jest na mężczyznach i ich potrzebach. Ponieważ wygodę ubrań cenili wysoko także młodzi mężczyźni, można przyjąć, iż ogólna dyspozycja do brania pod uwagę i dobrego traktowania siebie, utrwala się w trakcie całego życia mężczyzny. Pewne ustępstwa w tym zakresie czynili tylko mężczyźni będący w wieku średnim - w okresie intensywnego budowania/ugruntowywania swej pozycji społecznej (podkreślają wówczas głównie odpowiedniość stroju i jego szyk), aby na starość znów powrócić do wygody jako głównego kryterium przy zakupie 
i noszeniu odzieży. Wśród starszych respondentek natomiast wygoda stroju, wbrew racjonalnie uzasadnionym przypuszczeniom, nie odgrywała w sposobie ubierania się tak ważnej roli, jak na przykład posiadanie i trzymanie się własnego stylu oraz komponowanie kolorystyki stroju.

Wśród ludzi starych biorących udział w badaniu nie było też jednomyślności w sprawie preferowanego stylu ubierania: mężczyźni pozostali przy „sportowym” oraz „klasycznym”, a stare kobiety przede wszystkim dostrzegły wiele odmian stylu sportowego, zaś styl klasyczny opisywały inaczej niż mężczyźni.

Ponieważ respondenci współtworzący kategorię ludzi starych podkreślali przede wszystkim posiadanie i „trzymanie się własnego stylu ubierania", warto za Grażyna Bokszańską zauważyć, że pod takim sformułowaniem może kryć się równie dobrze styl wybrany dla siebie spośród licznych propozycji lansowanych jako modne, podobnie jak naprawdę własne, "twórcze przetworzenie stylu proponowanego przez modę" (Bokszańska 2004: 29). Jak wynika $\mathrm{z}$ analizy wypowiedzi na ten temat, w przypadku naszych badań kreatywność w tym zakresie deklarowały seniorki. Starsi panowie natomiast pod określeniem „własny styl” rozumieli odrzucanie najnowszych trendów w modzie na rzecz klasyki, wyróżniając jej dwie formy: elegancką (noszenie garnituru) i sportową. Poza tym swój styl ubierania starzy mężczyźni określali jako „gustowny” albo "spokojny”: „Z wiekiem zacząłem się spokojniej, tradycyjnie ubierać" (MST_2_63).

Wśród wielu kryteriów pozwalających klasyfikować ubiory G. Bokszańska wymienia także: „stosunek do reguł, standardów i wzorów obowiązujących w danej zbiorowości”, dodajmy - w danym porządku społecznym. Z tego punktu widzenia autorka wyodrębnia ubiory świadczące o konformizmie i o nonkonformizmie. Styl spokojny, klasyczny jest w myśl tej koncepcji oznaką akceptacji obowiązujących norm i zasad, wyraża konserwatyzm (Bokszańska 2004: 29). Preferując klasyczny, stonowany styl ubierania, starzy mężczyźni będący uczestnikami omawianego badania ujawnili zatem zachowawczy stosunek do patriarchatu jako panującego porządku społecznego. (Ich konserwatyzmowi, tu przejawiającemu się akurat w stylu ubierania, mogła jednak sprzyjać także przynależność do kategorii osób starych).

Starsze kobiety wyodrębniały więcej stylów ubierania i dokonywały ich dokładniejszego opisu niż rówieśnicy. Wymieniały na przykład trzy rodzaje stylu sportowego: „sportowy elegancki” do noszenia poza domem, sportowy styl dresowy „zarezerwowany do domu” (KST_5_67) i styl sportowy jako przeciwstawiony "eleganckiemu, dostojnemu” (KST_7_7o), który występował w dwóch odmianach: jako wizytowy, zauważalny, robiący wrażenie oraz jako strój formalny będący 
przeciwieństwem niezobowiązującego, wygodnego stroju. Niektóre respondentki uważały, że elegancji może towarzyszyć niekonwencjonalność ubioru, polegająca na nieliczeniu się ze swym wiekiem: „[...] ubieram się elegancko i dosyć odważnie jak na mój wiek. Bo się ubieram w takie rzeczy, które większość pań w moim wieku by nie włożyła” (KST_8_70). Inne podkreślały, że nie liczą się z cudzymi opiniami na temat ich sposobu ubierania się: „[...] ja zgodnie $\mathrm{z}$ własnym gustem dobieram odpowiednie kolory i fasony, a co sądzą inni, to nie zwracam na to uwagi" (KST_10_71). Z drugiej strony, wspomniano jednak nieśmiało o konieczności ubierania się stosownie do wieku: „Staram się ubierać w takie rzeczy, które przystoi starszej osobie. Nie za krótkie spódnice, nie za bardzo jaskrawe stroje, raczej stonowane kolory" (KST_12_84).

Ważną kwestią dotyczącą ubioru okazała się dla starych kobiet kolorystyka: „Kolory jasne, ale ciemne też, szary, niebieski, biały” (KST_1_64); „Ja się ubieram przeważnie w beżo-brązy [...]” (KST_14_86). Mówiły bardzo dużo o kryteriach, według których wybierają kolory dla siebie. Zwracają więc uwagę na to, aby „dobrze czuć się” w danym kolorze, biorą pod uwagę modę na kolory, dobierają kolorystykę ubrania do pogody itp. Stare kobiety lubią bawiąc się kolorami komponować swe ubiory, mają paletę własnych kolorów - mogą być ciemnej lub jasnej tonacji, mogą być „stonowane [...], które przystoją starszej osobie" (KST_13_85).

Zdaniem badaczy głównym kryterium pozwalającym odróżnić strój kobiecy od męskiego jest właśnie barwność stroju oraz krój podkreślający budowę kobiecego ciała (a rozmówczynie bardzo zwracały uwagę na dopasowanie ubrania do sylwetki). Opisywany przez kobiety metrykalnie należące do osób starych stosunek do kolorystyki własnego ubrania jest więc wskaźnikiem ich kobiecości. Co więcej, w myśl wspomnianej już typologii ubioru skonstruowanej według kryterium, jakim jest „stosunek do reguł, standardów i wzorów obowiązujących w danej zbiorowości", różnorodny w stylu i kolorowy ubiór wyraża brak satysfakcji jednostki/grupy ze status quo, dążenie do zmiany (Bokszańska 2004:29). W tym sensie starsze kobiety można postrzegać jako osoby kontestujące porządek patriarchalny. O męskim charakterze stroju starszych respondentów informował z kolei spokojny styl ubioru oraz preferowanie stonowanej, dyskretnej kolorystyki: „Raczej lubię kolory pastelowe, spokojne. Nie lubię kolorów krzykliwych, jasnych, w tym sensie marynarek. Natomiast spodnie latem, tak jak dzisiaj, (jasne - przyp. aut.) dopuszczam" (MST_4_64), „W kolorach bardziej takich [...] normalnych, stonowanych, jak to się mówi” (MST_8_70). Jak pisano wcześniej, ta „klasyka” męskiego ubioru świadczy równocześnie o - zrozumiałej zresztą w przypadku tej kategorii płci - akceptacji porządku patriarchalnego. 
Najbardziej zauważalna różnica $\mathrm{w}$ wypowiedziach starych kobiet i starych mężczyzn na temat sposobu ubierania się polegała jednak na tym, że żaden z mężczyzn nie zwrócił uwagi na konieczność dopasowania ubioru do swej sylwetki. Respondentki odwrotnie - czuły obowiązek podobania się: mówiły o tuszowaniu ubiorem wad w budowie ciała i nadwagi oraz o podkreślaniu zalet swej figury. Jest to, zgodnie z przytoczoną nieco wyżej koncepcją, kolejny wskaźnik kobiecej tożsamości respondentek reprezentujących w naszym badaniu pokolenie starych kobiet. Interesującą i genderowo uwarunkowaną różnicą stosunku do ubioru kobiet i mężczyzn z tej kategorii wieku było to, że kiedy mówiono o „ubieraniu się zgodnie z samopoczuciem", w przypadku mężczyzny zawsze oznaczało to, że to on w danym ubraniu „czuje się swobodnie”, wygodnie (MST_1_63), w przypadku kobiety znaczyło to również, iż w tym ubraniu może się pokazać innym: „lubię się ubrać tak, żebym się dobrze czuła, ale i żebym w tym dobrze wyglądała. Przecież wiadomo, że trzeba to (niedoskonałości sylwetki - przyp. aut.) jakoś zatuszować" (KST_4_66).

Pogłębiona analiza wypowiedzi respondentów z omawianej kategorii wieku pozwala zauważyć rezultaty udanej patriarchalnej - genderowej socjalizacji tego pokolenia. Starzy mężczyźni, stawiając w dbaniu o ubiór na własny styl i osobistą wygodę, przejawiali zinternalizowane poczucie podmiotowości. Stare kobiety stwarzały natomiast pozory upodmiotowienia. Kreowały, co prawda, swoje style ubierania, niejednokrotnie odmawiały ślepego nadążania za modą (choć jej nie ignorowały), niektóre nawet odmawiały spełniania oczekiwań co do przyjmowania takiego stylu ubierania, który podkreślałby ich przynależność do ludzi starych. Równocześnie jednak w usilnym dążeniu do bycia zauważoną, do podobania się innym oraz do uchodzenia za młodszą niż w rzeczywistości, pozostały konformistyczne wobec patriarchalnego ideału kobiecości, wspierając tym samym ciągły proces uprzedmiotowienia kobiety $\mathrm{w}$ tej kulturze (por. Malinowska 2016).

Jeśli chodzi o dbanie o ciało, dla ludzi należących do najstarszego pokolenia nie był to temat nadający się do szerokiego omawiania. Z wypowiedzi respondentów płci obojga wynikało, że podstawowe czynności w tym zakresie mają codzienny, rutynowy charakter i są tak zwykłe, że trudno o nich opowiadać. Chętniej i więcej mówiły jednak na ten temat kobiety. Mężczyźni stwarzali raczej wrażenie, że wolą być postrzegani nie jako dbający o ciało, lecz jako ci, którzy po prostu „dobrze się trzymają". Osoby obu płci wymieniły przede wszystkim pielęgnację ciała przy pomocy zabiegów wykonywanych samodzielnie i w domu, następnie dbanie o higienę osobistą oraz aktywność fizyczną.

Starsze kobiety przede wszystkim wykonywały zabiegi polegające na elementarnym zadbaniu o skórę całego ciała: „Na noc, jak po kąpieli, 
to balsam na ciało, bo ciało nie takie jak pani, bo moje już jest stare, już jest takie, no inne" (KST_3_65). Sporadycznie wykonywano bardziej specjalistyczne czynności: „[...] na przykład nakładam na ciało ten krem na cellulit" (KST_3_65). Tylko kilka respondentek wspomniało o pielęgnacji twarzy, jak nakładanie maseczki lub używanie specjalnego kremu. Mniej niż połowa respondentek $\mathrm{z}$ tej kategorii wieku wspomniała o typowej skądinąd czynności, jaką jest robienie makijażu; mówiły przy tym o makijażu raczej korygującym niż upiększającym. Miał on poprawiać samopoczucie, a zdaniem niektórych rozmówczyń jest niezbędny, gdy kobieta wychodzi z domu:

No na pewno to, że troszeczkę sobie oko umaluję czy make-up jakiś zrobię na twarz, ale bardzo lekki, bo nie jestem osobą preferującą nakładanie dużej ilości tych sztucznych rzeczy, bo ja nie jestem z tego pokolenia, tym niemniej lubię ładnie wyglądać, nie wyjdę nigdy bez umalowanych ust na ulicę, mam taki nawyk czy przyzwyczajenie i to mi dodaje trochę blasku (KST_2_64).

Oczywiście wymieniano także (niemal połowa respondentek) dbanie o włosy i fryzurę; niektóre z pań zwracały uwagę na wygląd dłoni. Tak więc starsze kobiety opisywały elementarne dbanie o siebie, czasem uzupełniając ten zwyczaj kroplą perfum zamykającą codzienny rytuał: „Dobre perfumy. Ulubione, które po prostu mam zawsze pod ręką i one podnoszą jakoś tak, całą moją [...]" (KST_4_66). Żadna z kobiet reprezentujących najstarsze pokolenie nie wspomniała o poddaniu się upiększającym zabiegom chirurgicznym czy też o interwencji kosmetycznej (por. Malinowska 2016).

Repertuar zabiegów pielęgnacyjnych wykonywanych samodzielnie w domu przez starych mężczyzn był skromniejszy. Należało do niego przede wszystkim codzienne lub nieco rzadziej wykonywane golenie i, jako czynność realizowana już poza domem, regularne strzyżenie włosów: „Muszę mieć krótkie włosy obcięte, no i ogolony. Jak nie jestem ogolony to nie idę nigdzie. Co dwa dni się golę" (MST_12_72). Jako rutynową czynność wskazano też poranny i/lub wieczorny prysznic. Starsi mężczyźni okazjonalnie dbali o ręce i o skórę całego ciała (profilaktyczne smarowanie kremem w słoneczne dni): „No wiadomo, że wieczorny prysznic, poranny prysznic, poranne golenie, no dbałość chociażby o przysłowiowe paznokcie, no, no takie rzeczy są bardzo ważne" (MST_5_64). W związku z tym używali na co dzień podstawowego zestawu kosmetyków: kremu do golenia i wody po goleniu, kosmetyków do włosów i okazjonalnie perfum: „Krem po goleniu czy jakaś woda po goleniu, szampon dobry do mycia włosów, odpowiednio dobrany do moich włosów, gdzie nie będzie o jakichś zapachach różanych się kojarzyło. Kremy nawilżające, 
natłuszczające po opalaniu" (MST_11_71). Nieliczni spośród respondentów dbający o swe dłonie i skórę czynili to tylko okazjonalnie: „Tylko jeszcze krem do rąk, od czasu do czasu, albo jak na działkę jedziemy i straszny upał, to mnie wysmaruje kremem, żebym się nie poparzył słońcem. To już żona pilnuje" (MST_8_70). Warto, za jednym z uczestników badania, podkreślić właśnie rolę kobiet - żon, córek w wyrabianiu ponadstandardowych nawyków w omawianym zakresie.

Interesująca różnica między starymi kobietami i starymi mężczyznami jeśli chodzi o dbanie o ciało dotyczyła nie tylko listy wykonywanych czynności, ale także powodów, dla których były one podejmowane. Dla kobiet ważne były względy estetyczne i związana z tym poprawa samopoczucia. Dla mężczyzn z kolei - ważne były powody higieniczno -zdrowotne, czasem tylko towarzyszyły im względy estetyczne (jak przy okazji golenia, strzyżenia).

Nikt nie wspomniał o konieczności wysypiania się, o poddawaniu swego ciała zabiegom chirurgicznym/kosmetyce interwencyjnej. W świetle analizowanych wypowiedzi nawet standardowe wizyty w gabinecie kosmetycznym nie są w zwyczaju starych kobiet (względy ekonomiczne? brak czasu? brak pomysłu?), a co dopiero mężczyzn (względy kulturowe czy inne?).

Dbanie o ciało to także szeroko rozumiane ćwiczenia fizyczne. W analizowanej grupie wiekowej kobiety deklarowały większą i bardziej różnorodną aktywność fizyczną niż mężczyźni i to głównie realizowaną poza domem, w różnych kręgach społecznych, czasem w towarzystwie własnego męża. Była to gimnastyka połączona z pływaniem, spacerowanie, jazda na rowerze. Mężczyźni zdawali się więcej mówić niż robić w zakresie aktywności fizycznej. Jeśli deklarowali wykonywanie jakichś ćwiczeń, to robili je nieregularnie i w domu: „Ja zawsze, jak mówię, troszeczkę te kości trzeba rozruszać rano, jak wstaję, więc jakieś tam ćwiczenia robię gimnastyczne" (MST_7_67). Tylko jeden respondent, z młodszej podzbiorowości w grupie starych mężczyzn, miał do powiedzenia coś konkretnego na temat swej aktywności fizycznej: „Spacery, dwa razy w tygodniu biegam, raz chodzę na basen" (MST_4_64). (por. Malinowska 2016).

Podsumowując ten fragment rozdziału - zachowania ludzi młodych dotyczące dbania o wygląd wydają się podlegać zandrogynizowanej genderyzacji, charakterystycznej dla epoki unowocześnionego patriarchatu, tzn. dopuszczającej nowe wzory płciowego podziału ról społecznych (np. dostęp kobiet do przynajmniej niektórych ról męskich, podejmowanie przez mężczyzn ról społecznych w modelu kulturowym definiowanych jako kobiece) oraz zezwalającej obu płciom na gromadzenie i wykorzystywanie wszelkich zasobów kapitału ludzkiego - w tym 
analizowanego tutaj tradycyjnie kobiecego wyglądu. Innymi słowy, $\mathrm{w}$ świetle uzyskanych wyników można zauważyć podobieństwo wzorów zachowań realizowanych przez ludzi młodych obojga płci. Główną różnicę stanowiła niesumienność mężczyzn $\mathrm{w}$ dbaniu o ciało i sprawność ruchową. Powstaje ogólniejsze pytanie - czy androgynizacja nie jest przejawem działania jeszcze jednego z samozachowawczych mechanizmów reprodukujących porządek patriarchalny? Można przypuszczać, że zmodyfikowany ideał męskości wykorzystujący kulturowo kobiecy kapitał ludzki, jakim jest atrakcyjny wygląd, pomaga mężczyznom skuteczniej konkurować ze społeczną ekspansją kobiet, które nie tylko zdobyły dostęp do edukacji i osiągnęły na tym polu więcej niż mężczyźni, ale zyskują rzeczywistą podmiotowość, awansują społecznie jako kategoria płci.

Jeśli chodzi o interesujący nas tutaj behawioralny komponent postawy, przedstawione wyniki analizy działań korzystnych dla atrakcyjnego wyglądu potwierdziły hipotetyczne twierdzenie o tym, że w przypadku młodych ludzi płeć słabo różnicuje postawy wobec wyglądu. W świetle zebranych wypowiedzi dbanie o ubiór i ciało przez biorących udział w badaniu ludzi starych, zdaje się, zgodnie z patriarchalnymi kulturowymi koncepcjami płci, bardziej i inaczej absorbować kobiety niż mężczyzn, potwierdzając tym samym przyjęte przez nas hipotetyczne twierdzenie o genderowym zróżnicowaniu tego aspektu postawy wobec własnego wyglądu, zwłaszcza wśród ludzi starych.

\subsubsection{Dbanie o swój wygląd przez kobiety w różnym wieku}

W tej części rozdziału podjęto próbę odpowiedzi na pytanie, jak wygląda wzór patriarchalnej kobiecości realizowany w odniesieniu do wyglądu przez kobiety należące do różnych kategorii wieku: młode, będące w wieku średnim i stare. Innymi słowy, zmierzamy do zidentyfikowania empirycznych przejawów genderyzacji wieku na przykładzie behawioralnego aspektu postawy kobiet wobec swego wyglądu.

Jak już pisano (podrozdz. 1.1, 3.1.3) w kulturze patriarchalnej wygląd jest głównym kapitałem ludzkim kobiety; potwierdza i nadaje znaczenie jej egzystencji, wpływa decydująco na jakość i przebieg jej życia. Jednym z najważniejszych celów socjalizacji w przypadku dziewczynki jest zatem wpojenie jej przekonania o wysokiej wartości wyglądu, a co za tym idzie - przeświadczenia o koniecznym obowiązku dbania o ten zasób: o ubiór i ciało. Sylwetka, uroda, cera, karnacja itp., czyli wrodzone cechy ciała, do niedawna uznawano za niepodlegające zasadniczej ingerencji zewnętrznej. Współcześnie jest to tylko częściowo prawdziwe, powszechnie jednak to ubiór pozostaje głównym narzędziem aranżowania wyglądu. 
Analizując wypowiedzi respondentek na temat ich sposobów ubierania się, można było odnieść wrażenie, że przynajmniej niektóre z nich, zwłaszcza kobiety z najstarszej kategorii wieku, zdają sobie sprawę ze znaczenia posiadania własnego stylu. Tak jakby i one mogły usłyszeć, co kilkadziesiąt lat temu Frieda Loehmann powiedziała młodziutkiej wówczas, współczesnej ikonie stylu Iris Apfel: „Młoda damo, przyglądam ci się. Nie jesteś ładna i nigdy nie będziesz, ale to bez znaczenia. Masz coś o wiele lepszego: masz styl" (za: Staniszewska 2016).

Charakteryzując działania podejmowane dla uatrakcyjnienia wyglądu, kobiety biorące udział w badaniu wiele mówiły o zasadach, którymi kierują się przy kupowaniu odzieży i komponowaniu swojego stroju. Podstawową maksymą, choć stosowaną głównie przez kobiety młode i stare, było właśnie wypracowywanie własnego stylu w ubieraniu się. W przypadku kobiet młodych, patriarchalnie uwarunkowanym powodem pracy nad własnym stylem mogło być dążenie do pozytywnego wyróżnienia się na tle całej zbiorowości rówieśnic $\mathrm{w}$ celu przyciągnięcia (i zatrzymania) właśnie na sobie uwagi mężczyzny, najlepiej „atrakcyjnego” według patriarchalnych standardów męskości. Motywem kierującym działaniami kobiet starych mogło być $\mathrm{z}$ kolei dążenie do pozostawania $\mathrm{w}$ orbicie zainteresowań płci przeciwnej oraz do opóźnienia - dzięki atrakcyjnemu, zadbanemu wyglądowi - momentu, od którego inni zaczną je bez wahania zaliczać do kategorii starych kobiet. W społeczeństwie patriarchalnym taka przynależność oznacza wystąpienie nakładających się przyczyn społecznej marginalizacji: z powodu należenia do (zdominowanej) „drugiej” płci, z powodu przynależności do ludzi starych i z powodu kobiecej starości - reprodukcyjnie już bezwartościowej. Respondentki w średnim wieku, które zdecydowanie rzadziej wspominały o wypracowywaniu własnego stylu, kładły akcent raczej na inne aspekty dbania o atrakcyjny ubiór. Być może dlatego, że ze względu na swój wiek znalazły się właśnie w okresie poszukiwania nowej koncepcji odpowiedniego dla nich stylu, tzn. takiego, który już nie nawiązuje bezpośrednio do wzoru młodzieżowego, a jednocześnie nie będzie ich przedwcześnie postarzał? Poza tym kobiety w średnim wieku, jako na ogół ustabilizowane życiowo, nie muszą już konkurować z innymi kobietami jak wtedy, gdy były młode i uczestniczyły w instytucji rynku matrymonialnego, debiutowały na rynku pracy itp., a z drugiej strony nie muszą jeszcze walczyć o to, by dzięki ubiorowi być dla innych, zwłaszcza dla swoich rówieśników, zauważalnymi, podczas gdy stare kobiety, nie tylko z powodu znacznej nadreprezentacji płci żeńskiej w zbiorowości ludzi starych, muszą walczyć o każde spojrzenie, zresztą nie tylko mężczyzn. Takie przypuszczenia znajdują potwierdzenie w typach preferowanych stylów ubierania charakterystycznych dla poszczególnych kategorii wieku. I tak na przykład młode respondentki 
opisywały swój styl jako elegancki/tradycyjny oraz nowoczesny/sportowy. Ten ostatni jest, ich zdaniem, „łatwy” w realizacji i noszeniu, co wyraźnie miało dla nich znaczenie. Część starszych kobiet opisujących swój styl także zaznaczała, że ich ubiór jest tradycyjny i elegancki, co w tym przypadku znaczyło raczej, że jest przemyślany - „gustowny”, zauważalny, gdyż dopasowany do wieku: „No ja raczej ubieram się tak tradycyjnie, bym powiedziała, no uważam, że w tym wieku to nie będę nosić jakichś getrów i tunik, bo jest tyle innych kobiecych ciekawych strojów" (KST_9_71). Ale inne kobiety z tej grupy wieku zadeklarowały niekonwencjonalny i kolorowy sposób ubierania oraz kultywowanie stylu sportowego, nowoczesnego, wyróżniając w nim kilka odmian.

Równie często wskazywaną zasadą stosowaną przez kobiety przy wyborze stroju było ubieranie się odpowiednio do okazji lub miejsca. W sytuacjach oficjalnych kobiety preferowały wybór eleganckiego i tradycyjnego ubioru, natomiast $\mathrm{w}$ zaciszu domowym kierowały się przede wszystkim wygodą. Powyższa zasada komponowania ubioru była stosowana przez respondentki ze wszystkich kategorii wieku.

Oddzielanie sfery domowej od przestrzeni oficjalnej było jednak utrwalone zwłaszcza w świadomości kobiet starych:

Pewno staranniej dobieram strój i ubieram się na wyjście tak, żeby to było adekwatne do miejsca do którego idę, nie ubieram się już wtedy w sukienkę dżinsową czy w spodnie dżinsowe, tu zawsze ma miejsce spódnica i żakiet albo kostium cały, różnego rodzaju dodatki - korale, bransoletki czy klipsy, uwielbiam klipsy, ale malutkie, nie lubię obwieszać się biżuterią [...] (KST_2_64).

Taki podział przestrzeni społecznej był dla tego pokolenia kobiet oczywisty i praktykowany przez większość z nich.

Do podziału na sfery aktywności społecznej odwołuje się zresztą jedna $\mathrm{z}$ wielu typologii ubioru omówionych przez G. Bokszańską, wyróżniająca przestrzeń pracy oraz przestrzeń rekreacji, czasu wolnego (Bokszańska 2004). W refleksji feministycznej, funkcjonalnej w kontekście analiz społecznych nierówności płci, ukazał się z kolei podział na strefę publiczną i prywatną, przy czym pierwsza $\mathrm{z}$ wymienionych była głównym obszarem aktywizacji mężczyzn, a druga domeną kobiet. „Ubiór pracowniczy", jak zwraca uwagę G. Bokszańska, ulega uniformizacji, inaczej mówiąc, jest dostosowany do oficjalnych wymogów określonej pracy (np. urzędniczej). O wiele większa swoboda, ale i trudność związana $\mathrm{z}$ jednoznacznym określeniem wzorów, dotyczy stroju rekreacyjnego, noszonego w zaciszu domowym lub w sytuacjach nieoficjalnych. Ten problem znalazł wyraz $\mathrm{w}$ wypowiedziach respondentek $\mathrm{z}$ różnych grup wiekowych, a szczególnie będących w średnim wieku: „Jak jadę 
z wizytą do sejmu, to nie ubiorę się jakbym szła na działkę albo na jakieś inne przyjęcie, musi być niestety garsonka, nie spodnie tylko spódnica, no inaczej staram się ubierać” (KSR_13_61) oraz starszych: „Chociaż do pracy ubieram się raczej standardowo, tzn. spódnica, spodnie i jakaś bluzka $\mathrm{z}$ reguły biała, chociaż też kolorowe, i żakiecik jakiś. Taki mam strój, taki garnitur urzędowy" (KST_10_71). Wysoka dziś aktywność kobiet $\mathrm{w}$ średnim wieku w sferze pracy wyjaśnia dodatkowo ich mniejsze niż $\mathrm{w}$ przypadku kobiet młodych oraz kobiet starych zainteresowanie tworzeniem własnego stylu, skoro ich codzienny ubiór w znacznym zakresie podlega instytucjonalnym regulacjom (choćby pewnemu rodzajowi uniformizacji), a weekendy pozwalają na powrót do młodzieżowego stylu sportowego.

Często wymienianym przez kobiety czynnikiem uwzględnianym przez nie w kompletowaniu stroju okazała się wygoda, choć nie było to dla nich najważniejsze kryterium. Okazało się, że za wygodą ubrania optują przede wszystkim kobiety młode i dotyczyło to nie tylko ubrań noszonych w zaciszu domowym, ale także tych codziennych strojów „formalnych”, a nawet tych na specjalne okazje. Część z tych kobiet przyznała na przykład, że $\mathrm{z}$ tego powodu lubi nosić spodnie oraz buty na płaskim obcasie. Tylko jedna $\mathrm{z}$ respondentek $\mathrm{z}$ tej kategorii wieku noszenie wygodnych ubrań wyjaśniła ówczesnym zaangażowaniem w rolę matki małych dzieci, a najstarsza spośród młodych kobiet przyznała, że dobiera strój raczej w taki sposób, aby się odmłodzić. Według respondentki odejmuje jej lat właśnie strój młodzieżowo-damski: „Ja się odmładzam np. strojem. Zauważyłam, że po trzydziestce zaczęłam nosić krótsze spódniczki [...], zaczęłam nosić sukienki [...]" (KM_15_36). Jak wspomniano, kobiety w średnim i starszym wieku zdecydowanie rzadziej podkreślały kwestię wygody ubrań, a jeśli już, to akcentując znaczenie dobrego kroju: „Żeby ubiór był dobrze skrojony, wygodny, bo wiadomo jak, żeby się w nim dobrze ruszać" (KST_4_66). Te respondentki zaznaczały także, że starają się nosić dobrze dopasowane obuwie.

Ważnym kryterium wyboru ubrań stosowanym przez kobiety okazała się też kolorystyka; wiek wyraźnie różnicował znaczenie nadawane temu czynnikowi. Średnio zainteresowane grą kolorami ubrań okazały się kobiety młode i w średnim wieku. Tym pierwszym - przypomnijmy - zależało głównie na wygodzie ubrań i ukochały kilka neutralnych kolorów, jak np. biel, czerń i szary, które zawsze do siebie pasują, a kobiety w wieku średnim były właśnie w procesie poszukiwania swego stylu, bazując na razie na stylu mniej lub bardziej narzuconym służbowo. Poza tym żadna z tych kategorii kobiet nie potrzebuje jeszcze, a zwłaszcza kolorem (i fasonem), przyciągać uwagi innych. Warto jednak zauważyć, że kobiety w średnim wieku były najbardziej świadome tego, czy określone 
kolory pasują do ich karnacji i stylu, bardziej niż inne: „Staram się dobierać kolory, w których moja cera wygląda dobrze. Chociaż bardzo lubię szary, ale nie wiem czy dobrze w nim wyglądam. Ale granaty, kolory malinowe to są kolory, w których wiem, że jakoś skóra lepiej wygląda w tym czasie. Takie kolory staram się wybierać" (KSR_1_38). Niektóre z nich preferowały zresztą barwy naturalne: „(Kolorystyka - przyp. aut.) stonowana ale z jakimś akcentem" (KSR_3_42), inne - były zwolenniczkami praktycznego doboru kolorów: „Staram się to tak dobierać żebym wiedziała, że jedno do drugiego będzie pasowało" (KSR_10_56). Kolorystyka ubrań okazała się natomiast żywiołem kobiet starych. Te respondentki dokładnie określały ulubione, najczęściej stonowane kolory, dostosowane do ich wieku: „Staram się ubierać w takie rzeczy, które przystoi starszej osobie. [...] nie za bardzo jaskrawe stroje, raczej stonowane kolory" (KST_12_84). Ale już inna ze starszych pań preferowała kolorowe ubrania: „Zadbana jestem i mam wrażenie, że się ubieram w moim odczuciu ładnie. Lubię kolorowe rzeczy, koronki, riuszki, falbanki, tak barwnie się lubię ubrać" (KST_10_71). Warto podkreślić, że kobiety w starszym wieku zwracały baczną uwagę na to, iż muszą „dobrze czuć się” w określonym kolorze:

[...] (w doborze ubrań - przyp. aut.) kieruję się kolorystyką, ponieważ ja uwielbiam beże, w związku z tym brąz, beż to są moje kolory i w takiej tonacji się ubieram, ja się w tym dobrze czuję, jak ja się w ten sposób ubiorę to ja się odbieram w lustrze pozytywnie (KST_2_64). Ja na przykład w ogóle nie noszę koloru czerwonego [...]. Czasami, na zasadzie kontrastu, jakiegoś gagu można sobie pozwolić, ale generalnie poruszam się w pewnym klimacie. Bo to jest zgodne z moją psychiką (KST_4_66).

Jak zauważa G. Bokszańska, sposób postrzegania i używanie kolorystyki ubrań wpisuje się w ogólnie obowiązujące konwencje estetyczne, będące jedną z reguł komponowania ubiorów, która jest definiowana kulturowo. Wykorzystanie odpowiednich zestawów kolorystycznych, łączenie ich i zestawianie, a także rezultat tych kombinacji to wyraz posiadanych przez jednostkę kompetencji kulturowych, innymi słowy znajomości panujących zasad i reguł estetyzmu (Bokszańska 2004: 40). Chociaż tradycyjne zestawienia kolorystyczne i zasady komponowania ubioru wydają się być najbardziej popularnym wzorem realizowanym przez respondentki z najstarszej kategorii wieku, należy wspomnieć także o celowym przełamywaniu tych zasad, będących przejawem postępowania awangardowego. Choć mowa tu o pojedynczych przypadkach, niektóre starsze panie okazały się odważne, jeśli chodzi o przeciwstawianie się patriarchalnej koncepcji kobiety zdominowanej, tu: konformistycznej wobec stereotypu wyglądu kobiety starej: 
[...] generalnie uważam, że się ubieram elegancko i dosyć odważnie, jak na mój wiek. Bo się ubieram w takie rzeczy, które większość pań w moim wieku by nie włożyła (KST_8_70). [...] lubię być ubrana, żeby nie wyglądać [...] jak stara ciotka, która w ogóle nie wie, jaka jest moda, co się aktualnie nosi (KST_8_70). [...] ja zgodnie z własnym gustem dobieram odpowiednie kolory i fasony, a co sądzą inni, to nie zwracam na to uwagi. Nie kieruję się modą. Bardzo mało się kieruję modą. Natomiast najważniejsze jest dla mnie to, że ja się w tym dobrze czuję (KST_10_71).

Kobiety poruszyły wreszcie także kwestię dopasowania ubioru do sylwetki. Oczywiście powinien on być dobrze skrojony i w przypadku młodych kobiet eksponować ich dobrą figurę, a w przypadku (niektórych) w średnim wieku, a zwłaszcza starych - tuszować jej niedoskonałości. Uwagi starych kobiet dotyczyły głównie nadwagi. Odzwierciedla to kobiecą potrzebę uatrakcyjniania swojego wyglądu, jednak sposób osiągania efektu jest odmienny dla kobiet w różnym wieku.

Kolejnym czynnikiem, który wpływał na dobór określonego stroju i jego elementów, była cena, ważna zwłaszcza dla kobiet w średnim wieku (jest to okres największych wydatków, zwłaszcza w rodzinach mających dzieci). Na ogół był to wpływ ograniczający: „[...] ograniczają mnie finanse, więc tyle na ile jest możliwość dbam o to, w miarę możliwości jest to dla mnie istotne” (KM_11_34). Podobnie kwestia ta wyglądała w przypadku kobiet w starszym wieku: „Kupuję sobie to, na co mnie stać i tak się ubieram” (KST_7_7o). Umiejętności gospodarowania dużym i małym budżetem rodzinnym w kulturze patriarchalnej oczekuje się głównie od kobiet jako gospodyń domowych (podobnie jak od mężczyzn - zarabiania na utrzymanie rodziny). Można przypuszczać, że dlatego nasze respondentki, zwłaszcza kobiety w średnim i starszym wieku, podchodziły do problemu zakupu ubrań bardzo rozważnie. Zwracały uwagę na jakość odzieży, na materiały, z jakich została wykonana. Być może nie jest to przypadkowe, ale na ten temat wypowiedziała się tylko jedna młoda kobieta i to w następujący sposób: „No, cena też ma znaczenie, ale nie jest to główny czynnik, to znaczy wolę sobie nawet trochę odłożyć i poczekać i kupić coś, co jest droższe, ale będzie lepszej jakości, będę to miała dłużej i będzie na przykład, nie wiem, lepiej uszyte, będzie mi w tym wygodniej” (KM_12_34). Niektóre z respondentek będących w starszym wieku przypomniały sobie natomiast zasadę obowiązującą w ich pokoleniu, a zwłaszcza w pokoleniu ich rodziców: „Lepiej, jak to się mówi, (mieć - przyp. aut.) jedną rzecz niż trzy, ale jak się należy" (KST_14_86). Te osoby zwracały uwagę na przykład na jakość butów, a w przypadku odzieży na to, aby była uszyta z naturalnych włókien: „Bo te sztuczne są ani dobre dla przyjemności, ani dobre dla zdrowia (KST_14_86). 
Jak wspomniano we wstępie tej części rozdziału (3.3.1.2.), pojmowanie ciała jako wytworu natury niepodlegającego ingerencji, w nowoczesnym świecie traci już sens. Ciało jest definiowane kulturowo, a te definicje ulegają zmianom, modom. Tak więc kobieta staje się atrakcyjna wówczas, gdy na skutek odpowiednich zabiegów spełnia aktualne standardy ideału kobiecej urody, zarówno jeśli chodzi o twarz, sylwetkę, jak i całe ciało. Problem polega na tym, że niektóre próby standaryzacji formy ciała lub jego fragmentów, na przykład „robienie” modnej twarzy, przynosi nieraz kuriozalne rezultaty. Dobrą ilustracją tego zjawiska były „usta Angeliny Jolie" przylepiane do jakichkolwiek twarzy, a wiadomo, iż bezkrytyczne kopiowanie jest wysoce ryzykowne, nawet gdy chodzi tylko o ubiór: „To, że Angelina Jolie wygląda w czymś bosko na czerwonym dywanie, nie znaczy wcale, że ty w tej samej sukience nie będziesz wyglądać jak koński zad" - przestrzega Iris Apfel (za: Staniszewska 2016). Ostatnio na przykład możemy obserwować masowe umieszczanie na twarzach kobiet maksymalnie wyregulowanych, depilowanych, a zarazem pogrubionych i przyciemnionych brwi - bez względu na wiek, karnację, owal twarzy, kształt oczu, nosa, ust i indywidualnych kompozycji tych wszystkich elementów. W efekcie niektórym młodym kobietom z dnia na dzień przybyło co najmniej po 10 lat; twarze innych stały się groźne, ponure; twarze nieciekawe zaczęły niepotrzebnie przyciągać uwagę, a niektóre ładne usta czy nosy stały się mniej widoczne niż sztucznie wyeksponowane brwi. Tak czy inaczej, w kulturze patriarchalnej wszystko, co dotyczyło i dotyczy wyglądu, miało i ma nadal istotne znaczenie, zwłaszcza w przypadku kobiet do niedawna niedysponujących niczym innym niż powierzchowność: ani prawami jednostki ludzkiej, ani wykształceniem, ani majątkiem (Malinowska 2012). Pojawiająca się natomiast (poruszana przez nas $w$ innych miejscach tego rozdziału) kwestia zmiany kulturowej dotyczącej znaczenia wyglądu w patriarchalnych koncepcjach płci - w interesującym nas tutaj kontekście polega na wzrastającej randze wyglądu w modelu męskości oraz na rozwoju świadomości społecznej związanej z wykorzystywaniem wyglądu jako elementu kapitału ludzkiego przez obie płci (w obu przypadkach zresztą wiek różnicował tę świadomość).

Zdecydowanie warta uwagi wydaje się ponadto coraz śmielej podejmowana refleksja również nad negatywnym wpływem atrakcyjnego wyglądu na życie współczesnych pięknych kobiet oraz nad doświadczeniem życiowym obecnie starych już kobiet, które z powodu niespełniania, od dzieciństwa, poprzez młodość aż po dzień dzisiejszy, żadnych z obowiązujących po drodze kanonów kobiecego piękna, zrozumiały konieczność dysponowania i wykorzystały posiadanie innego kapitału ludzkiego niż atrakcyjny wygląd: mniej efektownego, ale na ogół bardziej (bo dłużej) efektywnego. Jest nim wiedza, kreatywność, aktywność i ich 
wyniki. W jednym z wywiadów wspomniana już Iris Apfel, która została ikoną mody, mając 84 lata, stwierdziła, że „[...] wszystkie znane jej piękne dziewczyny, które bazowały tylko na swoim wyglądzie, gdy z upływem czasu traciły urodę, czuły się nikim" (Staniszewska 2016: 47) i przywołała opinię jeszcze innego autorytetu w dziedzinie wyglądu kobiety, tj. Coco Chanel, która miała powiedzieć: „[...] nic tak nie sprawia, że kobieta wygląda staro, jak desperackie próby wyglądania młodo" (za: Staniszewska 2016).

Niektórzy badacze, w tym M. Doquin, porównują próby wpisania się w panujący ideał piękna do działań podejmowanych przez sportowców, akcentując tym samym zjawisko trenowania swojego ciała. Zgodnie z tą koncepcją staje się ono „projektem”, nad którym kobiety pracują i który zmieniają w zależności od aktualnie panujących trendów (Doquin 1989: 105). Współczesny rozwój kosmetologii i medycyny estetycznej dostarcza im zresztą gotowych rozwiązań ułatwiających pielęgnację określonych partii ciała, a także umożliwia tuszowanie mankamentów urody.

Wszystkie respondentki biorące udział w badaniu zadeklarowały także podejmowanie działań dotyczących dbania o ciało oraz aktywność fizyczną. Najczęściej wypowiadały się na temat dbania o higienę osobistą; było to działanie priorytetowe dla kobiet w każdej grupie wiekowej. Pogłębiona analiza wypowiedzi respondentek pozwoliła wskazać (podobnie jak to było w przypadku analizy sposobów uatrakcyjniania ubioru) ich własne kategorie opisu tych działań, a następnie wydobyć specyfikę sposobu działania każdej z kategorii wieku kobiet. Najoszczędniej i najbardziej ogólnie wypowiadały się na temat dbania o swe ciało kobiety stare. Jest jednak symptomatyczne, że przede wszystkim to one mówily o utrzymywaniu higieny osobistej jak o swym obowiązku lub czynności „naturalnej”: „Ja dbanie o swoją higienę [...] uważam za obowiązek. Człowieka każdego, nie tylko mój, tylko każdego" (KST_3_65). Dla najstarszych respondentek były to czynności powszednie i rutynowe, a nie zabiegi pielęgnacyjne. Jeśli już opowiadały o „ponadelementarnym” dbaniu o ciało, dotyczyło to ograniczania skutków zmian spowodowanych procesem starzenia się: „Na noc, jak wie pani, jak po kąpieli, to balsam na ciało, bo ciało nie takie jak pani, bo moje już jest stare, już jest takie no inne" (KST_3_65). Niektóre starsze kobiety stosowały więc odpowiednie balsamy przeciw cellulitis, wiotczeniu i marszczeniu się skóry całego ciała oraz w celu nawilżenia suchej skóry; zazwyczaj po kąpieli. Najczęściej nie wymieniały z nazwy używanych kosmetyków, nie określały pielęgnowanych partii ciała. Mniejszą uwagę niż kobiety z pozostałych kategorii wieku, ale jednak także, stare kobiety poświęcały pielęgnacji dłoni i paznokci. Powodem nie była w ich przypadku dbałość o urodę rąk, lecz konieczność zareagowania na zauważalne pogorszenie się kondycji skóry 
dłoni wynikające z procesu starzenia się i z powodu wykonywania codziennych czynności w domu: „No teraz ostatnio to też ręce smaruję, bo takie się zrobiły, nie dłonie, tylko całe ręce [...] bo one mi się trochę marszczą. Ta skóra na rękach" (KST_14_86). Respondentki stosowały nie tylko odpowiednie kremy, ale sięgały też po tradycyjne, naturalne metody poprawiania stanu skóry na dłoniach i wzmacniania paznokci: „Cytrynę na ręce, żeby tam jak jakieś ziemniaki się obiera, czy coś. Przeważnie to w rękawiczkach robię wszystko, to nowe ziemniaki się obiera, to one te ręce się nie zabrudzą" (KST_3_65). Inna wspomniała także o używaniu suplementów diety wzmacniających paznokcie i poprawiających kondycję skóry. Tylko jedna spośród starszych kobiet opisała dokładniej wykonywane przez siebie zabiegi: „Kremy do twarzy, a nogi i rączki też sobie smaruję i dbam o ręce i robię sobie sama manicure. Sama, bo nie chodzę do manikiurzystki" (KST_13_85). Respondentki, które ukończyły co najmniej sześćdziesiąty trzeci rok życia, równie skromnie charakteryzowały dbanie o twarz. Rzadko wspominały o używaniu kremów oraz innych kosmetyków przeznaczonych właśnie do pielęgnacji skóry twarzy lub jej szczególnie wrażliwych partii. Ograniczały się do stosowania tego samego kremu na całą twarz, a najwyżej do robienia maseczek: „Maseczkę sobie kupuję, nakładam" (KST_3_65).

Jeśli chodzi o makijaż, starsze kobiety zwracały uwagę przede wszystkim na korygowanie lub ukrywanie mankamentów urody. Podobnie jak kobiety w średnim wieku, starsze preferowały nieprzesadny, delikatny makijaż, dostosowany do ich wieku (KST_2_64). O specyfice sposobu dbania o ciało przez stare kobiety przesądzało także zdecydowane preferowanie profesjonalnej opieki nad włosami i najczęstsze, spośród wszystkich kategorii wiekowych kobiet, korzystanie z usług fryzjerskich. Ponadto kobiety stare zdecydowanie wolały wszelkie tego typu zabiegi wykonywać samodzielnie w domu. W ogóle nie wspomniały o medycynie estetycznej. Stare kobiety dużo częściej mówiły natomiast o dbaniu o kondycję fizyczną i ruch, chociaż niektóre z nich także wspomniały o uprawianiu konkretnych sportów rekreacyjnych (na przykład o chodzeniu na basen lub jeżdżeniu rowerem). O wiele istotniejsze wydaje się jednak dla kobiet w starszym wieku utrzymanie sprawności ruchowej: jedna $\mathrm{z}$ kobiet mówiła na przykład o tym, że w jej wieku trudno jest wykonywać konkretne ćwiczenia, poprzestaje zatem na spacerach: „spacerować w miarę możliwości też dużo, bo na inną aktywność fizyczną to raczej mi się trudno zdobyć, bo jestem słaba, ćwiczenia mnie bardzo męczą, jakieś takie konkretne ćwiczenia" (KST_9_71).

Jeśli w przypadku kobiet młodych trening fizyczny ma na celu okiełznanie ciała, zbliżenie jego parametrów do panujących standardów piękna, to dla kobiet w starszym wieku istotne staje się utrzymanie ogólnej 
sprawności ruchowej i kondycji, pozwalającej im na samowystarczalność i niezależność $\mathrm{w}$ codziennym funkcjonowaniu. Ten fenomen nazywany jest przez niektórych badaczy „aktywnym przeciwstawianiem się starości” i dotyczy przede wszystkim praktyk czy też czynności podejmowanych przez starsze kobiety w celu przejęcia kontroli nad ich własnym, często cierpiącym na różne przypadłości, ciałem. Aktywności ruchowe mają na celu nie tylko przywrócenie bądź utrzymanie sprawności fizycznej, ale także dostarczają kobietom przeświadczenia, że stosując odpowiednie ćwiczenia, mogą opóźnić efekty chorobowe, a nawet ograniczyć niepełnosprawność ruchową. Należy jednak zaznaczyć, że nawet w wypowiedziach seniorek dostrzec można potrzebę podążania za obowiązującymi wzorcami kobiecego ciała. Jedna $\mathrm{z}$ respondentek stwierdziła na przykład, że uprawianie sportu może przyczynić się także do utraty wagi: „No i wie pani, jeżdżę rowerem żeby kondycję swoją poprawić no i może się odchudzę trochę" (KST_3_65).

Z powyższego opisu wyłania się, praktykowany przez stare kobiety, dość tradycyjny kulturowo (tj. patriarchalny) wzór kobiecości. Jest on przyswojony we wczesnej młodości, ukierunkowany na podkreślenie naturalnej urody preferowanej przez ówczesnych młodych mężczyzn (ale u potencjalnych kandydatek na żony). Ponadto jest to wzór zgodny z patriarchalnym i wewnętrznie sprzecznym ideałem kobiety tak atrakcyjnej, by mogła się podobać mężczyznom, a jednocześnie nie na tyle pięknej, by wzbudzało to wzmożone zainteresowanie jej wyróżniająca się urodą, sprawiając kłopot mężowi. Tak zwana „skromność” oczekiwana od kobiety wypełniającej rolę żony albo i matki w tym pokoleniu oznaczała wygląd naturalny: zero makijażu lub makijaż niemal niewidoczny, niemalowane paznokcie, niewyzywający strój, nie malowanie się do pracy itp. Takie wymagania stawiali ojcowie naszych respondentek ich matkom oraz narzeczeni/mężowie im samym w okresie młodości.

Kobiety dziś zaliczane do kategorii starych były ponadto uczone $\mathrm{w}$ procesie socjalizacji dbania o własne zdrowie i higienę osobistą (ważny warunek zdrowia reprodukcyjnego). Równocześnie jednak utwierdzaniu je w przekonaniu, że oglądanie i pielęgnacja własnego ciała jest nie tylko zbędna, lecz wręcz grzeszna, dowodzi „nieskromności” i braku wstydu. Można zauważyć, że nasze respondentki z tej kategorii wieku dbały niemal wyłącznie o te fragmenty ciała, które są odkryte, widoczne: twarz i dłonie oraz o włosy i fryzurę. To właśnie to pokolenie kobiet w latach 70/80 XX wieku z trudem pokonywało psychologiczną barierę na drodze do samokontroli piersi, upowszechnianej z powodu coraz częstszych przypadków zbyt późnego wykrywania nowotworów sutka. Na tym także polega wpływ patriarchalnej koncepcji kobiecości na sposób działania ponad sześćdziesięciotrzyletnich (i starszych kobiet) związany z dbaniem 
o ciało. Podobnie głównie prozdrowotny, rehabilitujący charakter miała ich aktywność fizyczna, podczas gdy kobiety młode traktują ją głównie profilaktycznie lub jako sposób na zachowanie młodej, zgrabnej sylwetki i urody.

O wzorze kobiecości wyłaniającym się z analizy działań podejmowanych przez kobiety w średnim wieku można z kolei powiedzieć, że jest już unowocześniony, ale ma charakter "przejściowy” między omówionym wyżej kulturowo-zachowawczym wzorem kobiet starych i ponowoczesnym, opartym na mitologizacji, a nawet nad-ocenie znaczenia wyglądu wzorem kobiecości realizowanym przez kobiety młode. W świetle wypowiedzi respondentek będących $\mathrm{w}$ średnim wieku polegał on na stosunkowo niewielkim, tzn. raczej porównywalnym z kobietami starszymi niż z młodymi, zaabsorbowaniu dbaniem o ciało. Oczywiście priorytetem było i w tym przypadku dbanie o codzienną higienę osobistą, ale tylko nieliczne respondentki $\mathrm{z}$ tej kategorii wieku mówiły o używaniu specjalistycznych kosmetyków do ciała, jak balsamy. Równie oszczędne są informacje na temat pielęgnacji stóp, dłoni oprócz stosowania zwykłych kremów i w kilku przypadkach malowania paznokci. Kobiety w średnim wieku zwracały natomiast uwagę przede wszystkim na makijaż: subtelny i delikatny. Sporo mówiły o sposobie jego wykonywania: używanie cieni do powiek, podkładu, różu i pudrów: „Nie mówię, że dużo, ale odrobinę, jakiś dobry róż, dobre cienie i odrobina jakiegoś podkładu to, to" (KSR_14_61). Część tych kobiet zaznaczyła ponadto, że stosują makijaż przede wszystkim w sytuacjach oficjalnych: „Maluję się, wychodząc do pracy, niekoniecznie do sklepu" (KSR_6_48).

Jeśli chodzi o pielęgnację ciała, kobiety w średnim wieku poświęcały uwagę twarzy i włosom. Znakomita większość respondentek w średnim wieku stosowała specjalne kosmetyki do skóry twarzy i pod oczy, dostosowane zresztą do wieku i typu skóry. Miało to na celu ukrycie pierwszych oznak starzenia się lub opóźnienie tego procesu. Częściej niż kobiety młode te respondentki korzystały z usług fryzjerów, zamawiając również farbowanie włosów. Przy tej okazji także wyraźnie zaznaczały, że chodzi im o ukrycie typowych oznak starzenia się: „Chodzę do fryzjera $\mathrm{w}$ miarę regularnie i w miarę potrzeby. Staram się tuszować mankamenty, czyli pierwsze siwizny [...]" (KSR_6_48). Fizyczna aktywność tej kategorii kobiet przybierała różne formy. Połowa rozmówczyń zadeklarowała uprawianie konkretnych sportów i/albo uczestnictwo w zespołowych zajęciach ruchowych (fitness, aerobik). Inne wymieniały wykonywanie ćwiczeń w domu oraz długie spacery podczas urlopu.

Powracając do omawianego $\mathrm{w}$ wywiadach tematu pielęgnacji ciała, kobiety w średnim wieku zdecydowanie rzadziej i mniej wypowiadały się na ten temat niż młode, choć teoretycznie mają już teraz więcej 
do zrobienia niż te pierwsze, a i same zaczynają odczuwać lęk przed starością. Kulturowym wyjaśnieniem tej niekonsekwencji może być fakt, że kobiety będące $\mathrm{w}$ momencie badania $\mathrm{w}$ średnim wieku są pokoleniem wychowanym przez obecnie stare kobiety, realizujące, jak ukazano wyżej, raczej wzór tradycyjnej kobiecości. Respondentki w średnim wieku pozostają więc pod wpływem dwóch modeli kobiecości: panującego w ich dzieciństwie, a nawet młodości i stosowanego w procesie ich pierwotnej socjalizacji patriarchalnego ideału kobiecości oraz występującej współcześnie androgynicznej kulturowej koncepcji płci.

Najwięcej do powiedzenia $\mathrm{w}$ kwestii dbania o ciało miały natomiast kobiety młode. Realizowały one wzór kobiecości, który, niezbyt oryginalnie, można nazwać ponowoczesnym, jeśli za jedną z ważnych cech tej epoki uznać fetyszyzację znaczenia wyglądu, zwłaszcza „zrobionej” jak na sesję fotograficzną twarzy oraz młodego, zadbanego ciała. Wypowiedzi młodych respondentek na temat korzystnych działań podejmowanych przez nie dla atrakcyjnego wyglądu ciała zaczynały się od podkreślenia znaczenia codziennego dbania o higienę osobistą. Ponad połowa z nich wymieniła przede wszystkim regularne kąpiele oraz dbanie o higienę jamy ustnej. Ponadto młode kobiety dokładnie określały sposób, w jaki pielęgnują ciało na co dzień: zdecydowana większość z nich dbała na przykład o odpowiednie nawilżenie skóry całego ciała, stosując odpowiednie balsamy i kremy; niektóre deklarowały także używanie peelingów. Te respondentki chętnie poświęcały czas na pielęgnację skóry dłoni, stóp i paznokci. Tylko młode kobiety wymieniały takie zabiegi jak depilacja oraz manicure i pedicure, a przynajmniej regularne stosowanie kremu do rąk. Podobnie zresztą jeśli chodzi twarz, której pielęgnacja polegała przede wszystkim na używaniu odpowiednich kremów i nakładaniu maseczek. Większość młodych kobiet zadeklarowała używanie specjalnych kremów na określone partie skóry twarzy oraz wspomnianych maseczek i peelingów. Koncentracja na wyglądzie twarzy - w tym robienie makijażu - cechowała również, jak pamiętamy, kobiety w średnim wieku. Jednak one walczyły z pierwszymi oznakami starości, a celem młodych kobiet jest ustawiczne poprawianie urody, „upiększanie się". Młode kobiety dbały także o włosy. Ten rodzaj pielęgnacji oznaczał zarówno stosowanie odpowiednich kosmetyków, jak i układanie fryzur, znacznie rzadziej zaś farbowanie włosów. Pielęgnacja włosów nie ograniczała się w tym przypadku jedynie do zacisza domowego, bowiem niektóre młode respondentki przyznały, że korzystają z usług profesjonalnych salonów fryzjerskich (odwiedzają też gabinety kosmetyczne). Warto zauważyć, że wyłącznie młode kobiety wypowiadały się na temat zabiegów medycyny estetycznej. Tylko połowa $\mathrm{z}$ nich jednak przyznała, że nie zdecydowałyby się na jakikolwiek profesjonalny zabieg interweniujący w ich wygląd. 
Młode kobiety okazały się także aktywne fizycznie: od uprawiania różnych sportów, po siłownię i ćwiczenia wykonywane w domu.

Intensyfikacja działań na rzecz ulepszenia wyglądu przez kobiety młode, $\mathrm{w}$ porównaniu $\mathrm{z}$ pozostałymi kategoriami wiekowymi, potwierdza wzrost znaczenia przypisywanego współcześnie aparycji i wizerunkowi kobiety. Czy chodzi tu o powrót do patriarchalnej koncepcji kobiecości, w której wygląd stanowił całe bogactwo kobiety i przesądzał o jej wartości? Dziś mitologizowanie znaczenia wyglądu nie powinno się udać. Przecież na kapitał ludzki współczesnej młodej kobiety składają się także przysługujące jej prawa, wykształcenie, doświadczenie zawodowe, często unikalne, nowoczesne i liczne umiejętności itd. A może podwyższanie rangi jej wyglądu, a co za tym idzie absorbowanie czasu kobiet czynnościami kiedyś uważanymi za trywialne ale bardzo „kobiece”, miałoby odwracać ich uwagę od innych ważnych spraw: ustawicznego, w każdym kolejnym pokoleniu pomnażania własnego kapitału ludzkiego w oparciu o inne składowe, tym samym czyniąc je mniej konkurencyjnymi na rynku pracy dla obecnie słabiej wykształconych i „bezradnych” tożsamościowo z powodu utraty roli jedynego/głównego żywiciela rodziny mężczyzn? (Dench 1998). Przeciw takiej, spiskowo-patriarchalnej hipotezie przemawia jedynie to, że do intensyfikacji zajmowania się swym wyglądem są dziś kulturowo zmuszeni także mężczyźni.

Podsumowując tę część analizy, możemy stwierdzić, że przynależność do kategorii wieku współwystępowała z odmiennością wzorów kobiecości realizowanych przez kobiety młode, w średnim wieku i stare, jeśli chodzi o dbanie o wygląd. Oczywiście kategorię wieku rozumiano socjologicznie, akcentując wspólny dla urodzonych w tych samych „czasach” zespół psychospołecznych warunków, w których przebiegał proces ich akulturacji do ówczesnej postaci społeczeństwa patriarchalnego.

\subsubsection{Dbanie o swój wygląd przez mężczyzn w różnym wieku}

$\mathrm{W}$ tej części rozdziału podjęto z kolei próbę odpowiedzi na pytanie, jak wygląda wzór patriarchalnej męskości realizowany w odniesieniu do wyglądu przez respondentów należących do różnych kategorii wieku: mężczyzn młodych, będących w wieku średnim i starych. Innymi słowy zmierzano do zidentyfikowania empirycznych przejawów gendered age na przykładzie behawioralnego aspektu ich postawy wobec swego wyglądu.

Fundamentem patriarchatu jako porządku społecznego jest podmiotowość mężczyzn obiektywizująca się w ich całkowitej, określonej kompleksowo jako symboliczna, dominacji (Bourdieu 2004) nad „drugą płcią" (de Beauvoir 2009). Definiowany w kategoriach kulturowych 
patriarchat opiera się na wskazanym wyżej modelu relacji władzy między kategoriami płci oraz na ściśle z nim powiązanych koncepcjach męskości i kobiecości. Wstępnym i głównym kryterium płciowego różnicowania socjalizacji, której przebieg ukierunkowują kulturowe koncepcje płci, jest zatem jej zasadniczy cel: przygotowywanie i wdrożenie chłopca - młodzieńca - mężczyzny do permanentnego pełnienia roli podmiotu oraz przygotowywanie i wdrożenie dziewczynki - dziewczyny - kobiety do permanentnego pełnienia roli jednostki zdominowanej: uprzedmiotowionej i posłusznej. Rozpatrując tę kwestię nadal teoretycznie - udana socjalizacja genderowa w odniesieniu do osobnika płci męskiej ma miejsce wtedy, gdy uczyni go mężczyzną, czyli istotą o głębokim poczuciu podmiotowości, nawet bez względu na uświadamianie sobie posiadania statusu podmiotu. W odniesieniu do istoty płci żeńskiej - wtedy, gdy zdoła wpoić jej uprzedmiotowienie, gotowość do bycia obiektem cudzych oddziaływań, nawet bez uświadamiania sobie funkcjonowania mechanizmu dominacji mężczyzn i własnego zdominowania lub statusu istoty uprzedmiotowionej: przecież „Nikt nie rodzi się kobietą, lecz się nią staje" (de Beauvoir 2009: 299). Tak więc każde zachowanie i działanie jednostki ludzkiej funkcjonującej w kulturze patriarchalnej - w zależności od jego/jej płci - jest naznaczone podmiotowością albo uprzedmiotowieniem.

Wiadomo, że model patriarchalny w rzeczywistości jest odwzorowywany na różne sposoby; patriarchat przybiera bowiem różne formy historyczne, w zależności od obowiązującej lub wpływowej religii, monizmu lub pluralizmu ideologicznego, ustroju politycznego, poziomu rozwoju cywilizacyjno-technicznego, dominującego sposobu produkcji, itp. (Malinowska 2008). Na przykład w warunkach demokratycznego społeczeństwa patriarchalnego podmiotowość mężczyzny zostaje dodatkowo wzmocniona, a w przypadku kobiety pojawia się szansa na uświadomienie sobie własnego uprzedmiotowienia i rozbudzenie potrzeby podmiotowości (Malinowska 1995).

Koncentrując się na analizie sformułowanego tu problemu, rozpatrywanego $\mathrm{w}$ odniesieniu do mężczyzn, należy zatem zidentyfikować zarówno przejawy uwewnętrznienia podmiotowości, jak i przejawy indywidualizacji podmiotowości mężczyzny obiektywizującej się w dążeniach emancypacyjnych od skonstruowanej z myślą o nim patriarchalnej koncepcji męskości. Na behawioralny aspekt postawy mężczyzn wobec własnego wyglądu proponujemy spojrzeć $\mathrm{z}$ takiej właśnie perspektywy teoretycznej.

Zmienną różnicującą jest przynależność mężczyzny do określonej kategorii wieku: do młodych, będących $\mathrm{w}$ wieku średnim i do starych mężczyzn. Jest to związane $\mathrm{z}$ hipotezą, iż najbliższe patriarchalnemu 
ideałowi męskości będą wzory zachowań związanych z dbaniem o wygląd realizowane przez pokolenie najstarsze, jako poddawane bardziej konsekwentnej i najdłużej trwającej patriarchalnej socjalizacji (pomimo transformacji społeczeństwa polskiego zachowuje ono patriarchalny charakter). Mężczyźni z młodego pokolenia będą natomiast ulegali presji indywidualistycznej i innym zmianom kulturowym płynącym z patriarchalnej ponowoczesności.

Opisując zachowania związane z dbaniem o swój wygląd, mężczyźni biorący udział $w$ badaniu informowali o działaniach związanych $\mathrm{z}$ dbaniem o ubiór oraz o zabiegach dotyczących ciała, w tym o swej aktywności fizycznej. Jeśli chodzi o ubiór, charakteryzując działania na rzecz korzystnego wyglądu, mężczyźni zwracali uwagę głównie na trzy rzeczy: posiadanie własnego stylu, dostosowanie ubioru do sytuacji i na czynnik dla nich równie ważny, jakim jest wygoda ubrania.

Potrzebę uwzględnienia wpływu silnego trendu indywidualistycznego w studiach nad ubiorem podkreśliła G. Bokszańska, pisząc: „Dominacja perspektywy indywidualistycznej we współczesnym społeczeństwie manifestuje się także na poziomie indywidualnych zachowań $\mathrm{w}$ dziedzinie ubioru, zwłaszcza jego koncepcji i przypisywanych mu funkcji” (Bokszańska 2004: 107). Wyniki naszych badań zdają się potwierdzać to spostrzeżenie. W wypowiedziach mężczyzn na temat sposobu ubierania, bez względu na ich wiek, dominował właśnie indywidualistyczny punkt widzenia. Mówiąc o stylu podkreślano, że to „własny” styl. Mówiąc o wybieraniu stroju zaznaczano „swoje” preferencje, a o kryteriach stosowanych przy kupowaniu odzieży - podkreślano „swoją" wygodę. Wskazując względy estetyczne jako przemawiające za dbaniem o wygląd - myślano o „własnych” przyjemnościach estetycznych, a nie o dostarczaniu zadbanym wyglądem przyjemności otoczeniu. Nawet przyznając się do konformizmu wynikającego z uznawanej przez nich zasady, iż należy ubierać się stosownie do sytuacji, mężczyźni dodawali chętnie własną definicję typu sytuacji albo odpowiedniości stroju. W jakimś zakresie każdy dąży do indywidualizacji sposobu ubierania, ale kobiety znacznie mniej niż mężczyźni eksponowały swoje „ja”, a także zdarzało im się stawiać siebie na drugim planie, jak na przykład wtedy, gdy kupowały coś ładnego/modnego kosztem wygody, gdyż dbając o swój wygląd, brały pod uwagę standardy estetyczne innych, licząc się z problemem akceptacji ze strony otoczenia (rzecz jasna, nie bez wyjątku). Ma to oczywiście związek z kompletnie różnym znaczeniem i funkcją wyglądu w patriarchalnych koncepcjach kobiecości i męskości, ale pozostaje aktualne już tylko w najstarszym i w średnim pokoleniu (one powinny, a oni nie muszą się podobać innym) (por. podrozdz. 3.1.3). 
W przypadku zbiorowości mężczyzn, podobnie zresztą jak było to wśród kobiet, wiek różnicował wypowiedzi. Przykładem może być rodzaj preferowanego stylu ubierania oraz jego definiowanie. I tak, starzy mężczyźni wymienili przede wszystkim styl tradycyjny, utożsamiając go $\mathrm{z}$ odrzucaniem mody lub z „trzymaniem się klasyki”. Młodszym mężczyznom bardziej zależało na byciu modnym, ale cenili przede wszystkim własny styl: „[...] uważam, że wyrobiłem sobie swój styl, taki zdefiniowany w mojej głowie i tego stylu się trzymam, jak idę do jakiegoś sklepu, bo muszę sobie coś kupić, to wybieram rzeczy, które bardzo mi się podobają i tworzą jakąś spójną całość" (MM_15_37). Mężczyźni w średnim wieku opisali preferowany przez siebie styl jako luźny: „[...] tak, jak teraz, na krótko, krótkie spodenki, na lajcie totalnym, [...]" (MSR_9_54), ale także jako szczególne połączenie stroju sportowego z formalnym: „[... więc dla mnie idealny jest taki ciuch na pograniczu elegancki i casualu, w tym czuję się absolutnie najlepiej" (MSR_1_38). Młodzi mężczyźni najczęściej określali swój styl jako luźny i młodzieżowy, informując, że zazwyczaj noszą bluzy, t-shirty lub jeansy. Rzadziej hołdowali tradycyjnej elegancji: tylko dwóch spośród piętnastu respondentów zadeklarowało wybór "gustownych" marynarek i koszul, ich zdaniem będących symbolem elegancji.

Przypomnijmy po raz kolejny, stosowane już przez nas za G. Bokszańską jako przydatne z punktu widzenia omawianej problematyki, jedno z kryteriów pozwalających klasyfikować ubiory. Chodzi o „stosunek do reguł, standardów i wzorów obowiązujących w danej zbiorowości" czy też ogólniej - w danym porządku społecznym. Przy jego pomocy można wyróżnić ubiory świadczące o konformizmie i nonkonformizmie. Styl spokojny, klasyczny jest uważany za oznakę akceptacji obowiązujących norm i zasad, wyraża konserwatyzm (Bokszańska 2004: 29). Preferując klasyczny, stonowany styl ubierania, starzy mężczyźni ujawnili zatem akceptację patriarchatu jako porządku społecznego. Jest to racjonalne, skoro ów reżim gwarantuje im status podmiotu, status grupy dominującej. Mężczyźni w średnim wieku wydali się przywiązani do patriarchalnej koncepcji męskości (ta atrakcyjna podmiotowość!), ale i otwarci na zmiany (być może dlatego, aby uchodzić za młodszych niż wskazuje na to ich wiek), zaś młodzi mężczyźni okazali się konformistyczni i nonkonformistyczni jednocześnie: przejęci byli dokonywaną właśnie w tym okresie życia poważną już aktywacją swego podmiotowego statusu, a jednocześnie poddawali się presji indywidualizacji oraz nowej koncepcji męskości uwzględniającej atrakcyjny wygląd jako składnik również męskiego kapitału ludzkiego.

Zdecydowanie najwięcej mężczyzn z każdej kategorii w wieku deklarowało jednak ubieranie się stosownie do sytuacji. Porządkując owe 
sytuacje, nawiązywali do pełnionych przez siebie ról społecznych i/lub typologizowali przestrzeń społeczną, w której ogrywali te role. Powtórnie przypomnijmy tutaj, że, jak pisze G. Bokszańska, umiejętność dostosowywania ubrania do wymogów określonej sytuacji lub miejsca wymaga znajomości konkretnych kodów kulturowych i konwencji dotyczących komponowania strojów. Strój może być jednak nie tylko integralnym elementem wizerunku, ale także nośnikiem informacji na temat pozycji społecznej, statusu ekonomicznego, a także przynależności jednostki do określonych grup i subkultur. Decyzje dotyczące zakresu komunikowanych informacji o sobie należą jednak do jednostki. Może ona zatem wykazywać się konformizmem, a więc ubierać się zgodnie z ogólnie przyjętymi zasadami i konwencjami estetycznymi, lub też w sposób oryginalny i odbiegający od konwencji, co często stanowi wyraz indywidualizmu i potrzeby manifestacji swojej odrębności (Bokszańska 2004: 40). Mężczyźni biorący udział w badaniu realizowali głównie pierwszy typ zachowań, różnicując ubiór przede wszystkim w zależności od sytuacji, ale także od sfery aktywności: prywatnej lub publicznej. W pierwszym przypadku wymieniano „ubiór domowy”, w drugim - ubiór „wyjściowy”. Strój odpowiadający wyłącznie sferze prywatnej charakteryzowała przede wszystkim funkcjonalność i prostota formy. Można powiedzieć, że przynależność do kategorii wieku nie różnicowała stylu; najwyżej inaczej określano ten sam typ ubioru (np. „koszulka” albo „t-shirt”). Drugi rodzaj przestrzeni odnoszono przede wszystkim do pracy, ale również do spotkań towarzyskich - także w cudzych domach oraz „wyjść”, np. do teatru. Wielu respondentów biorących udział w badaniu opisywało sposób ubierania się do pracy, nawiązując do panującego, a nawet narzuconego pracownikom odgórnie, dress codu: ,jak prowadzę szkolenie - to na pewno nie przyjdę $\mathrm{w} t$-shirtcie, tylko zawsze to musi być koszula: czy koszula $\mathrm{z}$ krawatem, czy bez krawata - nad tym się zastanawiam. I [...] dla kogo prowadzę [...], z kim się spotykam, czy mam porady indywidualne, czy nie mam. Czy będę jechał daleko w trasę, czy nie będę jechał" (MSR_4_40). Czasem jednak dawano wyraz swemu gustowi oraz sygnalizowano, że nawet ubierając się „formalnie”, realizuje się indywidualne upodobanie lub potrzebę. Chodziło tu zwłaszcza o to, aby „uniform” był jednak wygodny (o czym wspominali głównie mężczyźni $\mathrm{w}$ średnim wieku).

O stroju odpowiednim do charakteru pracy i stanowiska (a jak wynika z niektórych wywiadów nawet lepszym niż oczekiwany, jakby w myśl zasady „jeśli chcesz awansować na kierownika - wpierw wyglądaj jak kierownik") i o eleganckim ubiorze w sytuacjach ważniejszych wyjść, na przykład do teatru, mężczyźni w starszym wieku mówili jak o zinternalizowanym standardzie estetycznym. Niektórzy z nich podkreślali 
dbanie o odpowiedni ubiór właśnie po to, aby zaznaczyć swoją pozycję społeczną (a snując refleksję na temat genezy postawy wobec swego wyglądu, wspominali z młodości swoje aspiracje dotyczące awansu społecznego utożsamianego przez nich $\mathrm{z}$ innym stylem ubierania) (por. podrozdz. 3.1.3). W najstarszym pokoleniu dostrzeżono także zmianę w sposobie komponowania oficjalnego, wyjściowego ubioru oraz konieczność unowocześnienia realizowanego dotąd wzoru zachowania: „No tak, w tej chwili tak się moda zmieniła, że już do teatru założę marynarkę, załóżmy bez krawata i w dżinsach pójdę. A przedtem trzeba było już ten garnitur i taki pełen rynsztunek, a dzisiaj już nie i trzeba to też podpatrywać ludzi” (MST_9_70).

Młodzi respondenci także wyraźnie oddzielali strefę prywatną - domową od publicznej i zaznaczali, że ich sposób ubierania się jest inny w zależności od miejsca i okazji, w której biorą udział. Młodzi bardzo dokładnie opisywali sposób ubierania się w „sytuacjach oficjalnych”; strój składał się wtedy z koszuli, odpowiednich spodni oraz eleganckich butów. Pojęcie „sytuacje oficjalne”, oznaczało dla nich przede wszystkim spotkania i wyjścia w miejsca publiczne, do urzędów i pracy. Co wydaje się istotne, jeden $\mathrm{z}$ tych respondentów zaznaczył ponadto, że „[...] można ubiorem podkreślić swoją atrakcyjność" (MM_6_27). W ten sposób kulturowo typowo kobiece przekonanie o istotnym i pozytywnym społecznym znaczeniu dobrego wyglądu staje się częścią realizowanego wzoru męskości.

Również kilku mężczyzn w średnim wieku podniosło kwestię dostosowania swojego ubioru do określonej sytuacji. Podobnie jak młodzi mężczyźni, również ci respondenci wyraźnie oddzielali sferę prywatną od publicznej, podkreślając, że przestrzegają ogólnie uznanych norm dotyczących "formalnego" sposobu ubierania się. Wydaje się, że przywiązują oni do tej sprawy duże znaczenie, stąd asekuracyjnie bywają przygotowani nawet do szybkiej reakcji na zmieniające się sytuacje i oczekiwania co do ich ubioru: ,jak mam spotkanie oficjalne to wiadomo, że jest marynarka, krawat dyżurny w samochodzie i biała koszula w samochodzie cały czas czeka. [...] podwójne ubranie wożę [...]. Natomiast jeśli jest w planie jakiekolwiek spotkanie o którejkolwiek godzinie, no to jeszcze czasami przybory do golenia tzn. sprzęt do higieny codziennej ze sobą" (MSR_12_58). Inny z mężczyzn w średnim wieku zwrócił ponadto uwagę na odpowiednie ubranie się na spotkanie $\mathrm{z}$ kobietą.

Tak więc, choć mężczyźni w każdej grupie wiekowej byli świadomi znaczenia różnicy między strojami oficjalnymi i nieoficjalnymi, to o potrzebie dostosowania ubioru do wymogów sytuacyjnych mówili głównie młodzi respondenci i respondenci w średnim wieku. Po pierwsze jest to związane z ich aktywnością zawodową, która wycisza się lub wygasa już 
w przypadku starych mężczyzn. Młodzi i średni wiekiem zauważyli także wpływ wyglądu na atrakcyjność zawodową i towarzyską, a w związku z tym także taki „drobiazg”, że odpowiednio dobrany strój może podkreślić walory sylwetki lub maskować jej mankamenty: „[...] oczywiście [...] na pewno to jest i ten przejaw, że odkąd mam brzuszek to staram się chodzić z koszulami na wierzchu rozpuszczonymi, które w jakimś sensie ten brzuszek maskują" (MSR_15_61). Mężczyźni w starszym wieku w ogóle nie wspomnieli natomiast o wybieraniu takich ubrań, które podkreślałyby ich sylwetkę, jednak niektórzy zaznaczyli, że starają się ubierać stosowanie do swojego wieku. Przede wszystkim dotyczyło to tradycyjnych, eleganckich ubrań, pozbawionych ekstrawagancji: „ubieram się tak, jak starszemu panu wypada w tym wieku. Spodnie w kant, koszula, jakaś marynarka, buty klasyczne" (MST_8_70).

Jak już wspomniano, wygoda ubrań była dla mężczyzn jednym z trzech najistotniejszych (obok własnego stylu i dostosowania stroju do sytuacji) czynników, którymi kierowali się przy kupnie i komponowaniu stroju. Wiek różnicował te wypowiedzi: najczęściej o wygodzie mówili młodzi i starzy mężczyźni.

Pod określeniem „wygodny ubiór” młodzi mężczyźni rozumieli bluzy, t-shirty, dopasowane obuwie. Komfort był dla nich nie tylko ważnym, ale często najistotniejszym kryterium doboru ubrań: „dla mnie najważniejsza jest wygoda. Atrakcyjność jest rzeczą [...] drugoplanową. Jak powiedziałem, ja się nie wyróżniam $z$ tłumu i nie chcę się wyróżniać z tłumu [...], mam mieć wygodne buty, rzeczy, w których się dobrze czuję [...]" (MM_5_26). Taka wypowiedź potwierdza aktualność modelu patriarchalnej koncepcji męskości, w którym wygląd mężczyzny ma niewielkie znaczenie wobec określonych cech jego osobowości. Może także świadczyć o tym, że respondent nie ma problemu $\mathrm{z}$ atrakcyjnością swego wyglądu (wie, że jest akceptowany i sam go akceptuje), a wobec tego, może go uznać za drugorzędny. Empirycznym faktem jest natomiast, że $\mathrm{w}$ przeciwieństwie do młodych mężczyźni w starszym wieku pojęcie „wygodny strój” odnosili zasadniczo do ubrań noszonych w domu i jego najbliższym otoczeniu.

Dbanie o ciało, jeszcze bardziej niż starania o atrakcyjne ubieranie się, jest współcześnie przejawem procesu androgynizacji wzorów genderowych. Zacieranie się niektórych różnic między kobiecością a męskością wydaje się jednak dotyczyć głównie młodego pokolenia. Między innymi z tego względu podjęto referowane tutaj badania dotyczące uwzględniania w kulturowych definicjach płci, kategorii wieku kobiet i mężczyzn (gendered age). Powracając do przedmiotu analizy - w tym fragmencie rozdziału interesuje nas współwystępowanie $\mathrm{z}$ wiekiem respondentów ( $w$ kategoriach młodzi, średni, starzy) zróżnicowania 
zachowań związanych z dbaniem o ciało czyli do niedawna kulturowo kobiecą sferą działań.

Mężczyźni biorący udział w badaniach, bez względu na wiek, pielęgnację ciała utożsamiali najczęściej z utrzymywaniem higieny osobistej (regularne kąpiele, mycie zębów) oraz wykonywaniem codziennie takich czynności, jak golenie się i używanie kosmetyków po goleniu: „na przykład po goleniu korzystam ze świetnych balsamów, bo one rzeczywiście pomagają itd. natomiast te wyższe stopnie tej, tej [...] to już niestety finansowy problem" (MSR_15_61). Deklarowali także dbanie o włosy i fryzurę. W przypadku młodych mężczyzn dbanie o włosy dotyczyło zarówno ich mycia, jak i strzyżenia, wykonywanych przede wszystkim w zaciszu domowym: samodzielnie albo z pomocą bliskiej osoby, na przykład żony. Zdecydowanie rzadziej na ten temat wypowiadali się mężczyźni $\mathrm{w}$ średnim wieku, przy czym $\mathrm{w}$ ich przypadku pielęgnacja włosów dotyczyła utrzymywania odpowiedniej długości włosów, regularnego strzyżenia; niektórzy regularnie korzystali z usług fryzjera. Mężczyźni w starszym wieku mówili natomiast zarówno o strzyżeniu, o używaniu odpowiednich kosmetyków do włosów oraz zapewniali o regularnych wizytach u fryzjera. Jeden z respondentów zaznaczył ponadto, że nie używa kobiecych kosmetyków do włosów: „szampon dobry do mycia włosów, odpowiednio dobrany do moich włosów, gdzie nie będzie o jakiś zapachach różanych się kojarzyło" (MST_11_77).

Mężczyźni, bez względu na wiek, rzadko jednak wspominali o wykonywaniu określonych zabiegów związanych z pielęgnacją włosów. Być może właśnie dlatego, że jak wskazują niektórzy badacze (Synnott 1987), ten rodzaj troski o wygląd jest działaniem kulturowo przypisywanym kobietom, a po drugie - istnieje większa kulturowa akceptacja dla poddawania się przez kobiety zabiegom pielęgnacyjnym dotyczącym włosów niż w przypadku mężczyzn. Wydaje się, że to ustalenie nie dotyczy już przynajmniej młodego pokolenia. Jest jednak faktem potwierdzonym również w naszych badaniach, że mężczyźni najczęściej deklarowali jedynie wykonywanie elementarnych zabiegów. Zupełnie inaczej można natomiast interpretować wspominaną przez respondentów dbałość o zarost, który jest jedną $\mathrm{z}$ zewnętrznych oznak męskości, a nawet jednym z podstawowych atrybutów, często przeciwstawianym temu co kobiece (Synnott 1987).

Zabiegi pielęgnacyjne dotyczące całego ciała najczęściej i najdokładniej opisywali mężczyźni w młodym wieku, mówiąc na przykład o stosowaniu wybranych kremów do twarzy, w tym także produktów specjalistycznych do peelingu oraz maseczek i żelów oczyszczających.. Zaznaczali przy tym często, że korzystają tu z pomocy swoich partnerek: „Tak, kremy do twarzy i mam o tyle dobrze, że może raz w miesiącu, 
a może dwa razy w miesiącu, jak żona ma czas to mi nałoży jakąś maseczkę i sobie oglądam telewizję, także ona działa. I tak naprawdę zdarza nam się z żoną, jak się gdzieś tam wyjedzie, to jakiś masaż złapać" (MM_11_31). Mężczyźni w średnim wieku zdecydowanie rzadziej wypowiadali się na temat używania kremów i produktów pielęgnacyjnych przeznaczonych do skóry twarzy. Wspomniano na przykład o sporadycznym używaniu kremów pod oczy: „Czasem zdarzało mi się używać kremu pod oczy, kiedy jestem mocno zaspany, ale to też nauczyłem się tego od kobiet po prostu" (MSR_1_38) oraz o stosowaniu balsamów do twarzy: „Na twarzyczkę balsamy, żona też, żeby jakieś tam zmarszczki już tam ukrywać" (MSR_7_49). Podobnie jak to było w przypadku młodych mężczyzn, w wypowiedziach panów w średnim wieku można odnaleźć potwierdzenie wpływu ich partnerek życiowych na zmianę sposobu codziennej pielęgnacji ciała. Kobiety stanowiły zarówno wzór do naśladowania, jak i występowały w roli konsultantek. Jeśli chodzi o mężczyzn w starszym wieku, tylko nieliczni wspomnieli o używaniu kosmetyków do twarzy; podobnie jak w poprzednich przypadkach, niektórzy zaznaczali kierowanie się opiniami i wskazówkami kobiet, w tym córek.

$\mathrm{W}$ naszej kulturze perfumowanie się jest tradycyjnie uważane za zachowanie właściwe kobietom (Melosik 2006: 23). Jeśli chodzi o mężczyzn biorących udział w badaniu, najczęściej deklarowali używanie ulubionych zapachów młodzi mężczyźni; zaznaczali, że jest to dla nich istotna część codziennej pielęgnacji ciała: „Używam stosownych, według mojego uznania [...]. Wody po goleniu nie jakiejś tam najtańszej z kiosku ruchu, chociaż akurat nic nie mam do tej wody, ale uważam, że [...] zapach jest istotny" (MM_7_28). Zdecydowanie rzadziej na temat używania perfum wypowiadali się respondenci $\mathrm{w}$ średnim wieku i tylko pojedynczy panowie z kategorii najstarszej wiekiem. Dla wszystkich respondentów wody kolońskie i perfumy były dodatkiem mającym na celu uatrakcyjnienie wyglądu i wpłynięcie na pozytywne postrzeganie przez innych ludzi, w tym przede wszystkim przez kobiety. Nie tyle perfumowanie, co ów powód, dla którego nieliczni mężczyźni deklarowali używanie „pachnideł”, jest przejawem feminizacji męskiego kulturowego wzoru dbania o wygląd, a więc zarazem nonkonformizmu i indywidualizacji sposobu podejścia do swej fizyczności.

Mężczyzn w różnym wieku pytano także o dbanie o kondycję fizyczną, a więc o aktywność sprzyjającą utrzymywaniu sprawności, siły, zdrowia - typowo męskich, zgodnie z kulturową koncepcją tej płci, atrybutów. Nad doskonaleniem sprawności ruchowej pracowali przede wszystkim młodzi mężczyźni - ćwicząc w domu oraz na siłowni. Młodzi respondenci szczegółowo i wyczerpująco wypowiadali się na temat aktywności, którą podejmują, zarówno każdego dnia, jak i rzadziej: w większości dotyczyło 
to różnych form sportów rekreacyjnych, takich jak pływanie, gra w siatkówkę, jazda rowerem i bieganie. Wskazywali ponadto na potrzebę szeroko rozumianego treningu swojego ciała, który prowadzi zarówno do korygowania wagi ciała i sylwetki oraz do utrzymania odpowiedniej kondycji fizycznej i zdrowia. Z wiekiem było jednak coraz gorzej. Mężczyźni w średnim wieku wymieniali różne rodzaje aktywności fizycznej: były to zarówno ćwiczenia wykonywane w domu, jak i te odbywające się w ramach różnych zajęć ruchowych (np. fitness), a także spacery i jazda rowerem, ale najczęściej wykonywane od przypadku do przypadku, nieregularnie. Celem tej aktywności było przede wszystkim utrzymanie odpowiedniej kondycji: „Dbałość o kondycję fizyczną, czyli uprawianie sportów czynnych: jeżdżenie, bieganie, siłownia w domu, jakieś ćwiczenia fizyczne, żeby zachować formę fizyczną" (MSR_2_39). Tylko połowa starych mężczyzn zadeklarowała wykonywanie jakichkolwiek ćwiczeń pozwalających im utrzymywać sprawność ruchową: „Ja zawsze, jak mówię, troszeczkę te kości trzeba rozruszać rano, jak wstaję, więc jakieś tam ćwiczenia robię gimnastyczne" (MST_7_67). Ich aktywność fizyczna przyjmowała także inne, „łagodne” formy, jak np. spacerowanie: „Lubię spacery w ogóle, lubię spacery czasami wolne, ale ja w ogóle dość szybko chodzę, to też jest to" (MST_7_67). Starsi mężczyźni zdecydowanie częściej niż inni mówili natomiast o ograniczeniach, z jakimi muszą się mierzyć z racji swojego wieku: dotyczyło to zarówno problemów ruchowych, jak i związanych z procesem zmian zachodzących w ciele: „ćwiczę żeby nie mieć fałdów, celulitisu, jak się rozbiorę żeby moje ciało nie zwisało, czy pofałdowane, to dbam o to. Miałem okres, że wszystko mnie bolało, musiałem przerwać ćwiczenia" (MST_10_71). Wydaje się, że mężczyźni - zwłaszcza w średnim wieku i starzy - więcej mówili niż czynili w zakresie kultury fizycznej.

Jak wspomniano, uprawianie sportu i szeroko rozumiana aktywność fizyczna, w zależności od wieku miała inne motywacje. W przypadku młodych mężczyzn było to uatrakcyjnienie swojego wyglądu, dbałość o estetykę wyglądu i ciała. Młodzi mężczyźni biorący udział w badaniu motywowali uprawianie sportów przede wszystkim potrzebą spalenia tkanki tłuszczowej i rozwinięcia tkanki mięśniowej. Utrata masy ciała może mieć oczywiście zarówno charakter prozdrowotny, jak i służyć uatrakcyjnieniu wyglądu. Ćwiczenia ukierunkowane na wypracowanie mięśni mają natomiast charakter typowo estetyczny, zmierzający do uatrakcyjnienia wyglądu, a także, w szerszym znaczeniu, są przejawem realizowania tradycyjnego wzorca męskości. Uprawianie sportów i szeroko rozumiana aktywność fizyczna staje się więc współcześnie, szczególnie dla młodych mężczyzn, nie tyle wyrazem dbałości o kondycję i zdrowie, co akceptacją "mody na fitness”. Uprawianie sportów ulega 
komercjalizacji, staje się elementem stylu życia, przynajmniej częściowo zatracając swoją prozdrowotną rolę. Zupełnie inaczej sport postrzegany jest przez mężczyzn w starszym wieku. Po pierwsze nie chodzi im o podobanie się innym, co przewijało się zresztą w różnych fragmentach wywiadów, dotyczących różnych szczegółowych kwestii. Istotne stają się dla nich natomiast pewne aspekty zdrowotne - utrzymanie odpowiedniej sprawności ruchowej jest metodą przezwyciężania dolegliwości ruchowych wynikających z procesów starzenia się: „Bo teraz jak ma człowiek wolne, o, jak teraz wyjść na ogródek, coś tam porobić, nawet pochodzić $\mathrm{z}$ tą kosiarką, [...] dla mnie tym bardziej, jak ja ruchowo jestem trochę [...] po prostu blokowany ruchowo, bo mam blokadę tych, tych nóg" (MST_6_66).

Interesującym wskaźnikiem indywidualizacji i feminizacji wzoru zachowań mężczyzn związanym z dbaniem o wygląd były ich deklaracje dotyczące korzystania z usług kosmetyczek i salonów piękności. Kilku mężczyzn w młodym wieku wspomniało o poddawaniu się profesjonalnym zabiegom kosmetycznym: jeden $\mathrm{z}$ nich przyznał, że korzysta z usług manicurzystek i pedicurzystek, inny zadeklarował chodzenie na saunę, która pozytywnie wpływa na kondycję jego skóry. Mężczyźni w średnim wieku, podobnie jak młodzi respondenci, sporadycznie wymieniali korzystanie ze SPA oraz wykonywanie manicure u kosmetyczki, ale przede wszystkim za namową żony. Panowie w starszym wie$\mathrm{ku}$ zdecydowanie preferowali natomiast samodzielną pielęgnację ciała w zaciszu domowym - żaden z mężczyzn z tej kategorii wieku nie wymienił takiej formy dbania o wygląd, jak korzystanie z usług kosmetyczek i salonów piękności.

Podsumowując, przytoczone w tej części rozdziału wyniki badania pokazały, że przynależność mężczyzn do określonej kategorii wieku współwystępowała ze zmianą realizowanego sposobu dbania o wygląd. Starzy mężczyźni demonstrowali konserwatyzm w podejściu do patriarchalnie zdefiniowanej męskości, a tym samym wykazywali gotowość do reprodukcji tego porządku zapewniającego im, nawet nienazywane wprost, ale i tak miłe, poczucie podmiotowości. W analizowanym aspekcie postawy wobec własnego wyglądu przejawiało się to przede wszystkim w koncentracji na własnych wartościach i normach estetycznych oraz egoistycznej potrzebie samoakceptacji połączonej z psychiczną dyspozycją do przedmiotowego traktowania innych, zwłaszcza kobiet. Mężczyźni w średnim wieku ujawnili pewną skłonność do zmiany patriarchalnego wzoru działań na rzecz swego wyglądu. Dotyczyło to nieśmiałych prób feminizacji podejścia do ubioru (poza konformizmem wobec standardów obwiązujących w sferze pracy) i do dbania o ciało, w przypadku gdy ulegali już pewnym oczekiwaniom ze strony kobiet i korzystali z elementów 
kobiecego wzoru. Indywidualizacja tej sfery zachowań wystąpiła najwyraźniej wśród młodych mężczyzn. Ambiwalencja analizowanego aspektu postawy polegała $\mathrm{w}$ ich przypadku na tym, że młodzi równocześnie uświadamiali sobie dopiero atrakcyjne znaczenie podmiotowego statusu mężczyzny w patriarchalnej kulturze.

\subsubsection{Płeć kulturowa i upłciowiony wiek a dziatania niekorzystnie wpływające na wygląd (Joanna Brzezińska)}

W wywiadach swobodnych kobiety i mężczyzn w różnym wieku pytano również o to, czy podejmują jakieś działania, które są niekorzystne dla ich wyglądu, aby ustalić, czy zdarza się badanym robić coś, co szkodzi ich prezencji. Uczestnicy badania obu płci często niechętnie i nie bez wahania przyznawali się do różnego rodzaju złych nawyków, zdając sobie sprawę z ich negatywnego wpływu na własną aparycję. Jak zauważa bowiem Stefan Nowak w swojej definicji postawy: „model zachowania zawarty $\mathrm{w}$ komponencie behawioralnym i opatrzony odpowiednim ładunkiem afektywnym ma charakter instrumentalny, gdy nie tyle sposób zachowania się, co jego skutki są dla jednostki istotne" (Nowak 1973: 37). Wypowiedzi badanych wskazywały na wyraźnie emocjonalny stosunek do własnych zachowań ze względu na ich przykre konsekwencje właśnie.

Biorąc pod uwagę ogół odpowiedzi udzielonych na pytanie o działania szkodliwe dla wyglądu, można zauważyć, iż respondenci i respondentki odpowiadali podobnie. Wśród czynności wymienianych najczęściej zarówno przez kobiety, jak i mężczyzn znalazły się: złe nawyki żywieniowe, siedzący tryb życia i brak ruchu, korzystanie z używek, deficyt snu czy przepracowanie. Katalog działań niekorzystnych dla wyglądu w dużej mierze pokrywa się z działaniami, które negatywnie wpływają na zdrowie człowieka (patrz rozdział dot. postaw wobec wyglądu), a do których Polacy przyznają się ogółem (CBOS 2012c).

Podobieństwo zachowań uczestników badania okazuje się jednak pozorne, jeśli uwzględni się $\mathrm{w}$ analizie tego elementu postawowe kategorie płci, wieku oraz upłciowiony wiek (gendered age). W pierwszej kolejności omówione zostaną przejawy genderyzacji postaw wobec własnego wyglądu na podstawie porównania wypowiedzi kobiet i mężczyzn na temat czynności niekorzystnych dla ich fizjonomii.

Przede wszystkim należy zauważyć, że nie wszyscy badani przyznawali się do podejmowania działań o negatywnych skutkach dla ich wyglądu zewnętrznego. Co wydaje się interesujące, zdecydowanie częściej do tego typu zachowań przyznawały się respondentki, podczas gdy rzadziej takie deklaracje składali panowie. Zgodnie z patriarchalną koncepcją płci 
kulturowo wygląd zewnętrzny był i w dużej mierze wciąż jest traktowany bardziej jako atrybut kobiety aniżeli mężczyzny. Poprzez swoją atrakcyjną powierzchowność kobieta nie tylko buduje własną tożsamość, ale i uzyskuje akceptację społeczeństwa oraz pozytywną samoocenę. Upiększenie i poprawa określonych elementów twarzy i ciała ma służyć wyeksponowaniu jej kobiecości. W związku z tym patriarchalna koncepcja męskości zakłada znacznie mniejsze zainteresowanie mężczyzn własną aparycją, co znajduje swoje odzwierciedlenie również w świadomości ewentualnych działań niekorzystnych dla ciała człowieka, jakie podejmują respondenci płci męskiej. Fakt, iż blisko jedna czwarta respondentów wywiadów swobodnych (którzy udzielili odpowiedzi na omawiane pytanie) uznała, że nie zdarza im się robić nic, co mogłoby źle wpłynąć na ich powierzchowność, nie oznacza bowiem, że tego typu działań nie podejmują. $Z$ dużą dozą prawdopodobieństwa można przypuszczać, iż znaczna część mężczyzn nie uświadamia sobie niekorzystnych skutków pewnych czynności dla ich wyglądu, gdyż wygląd sam w sobie oraz troska o niego - w myśl patriarchalnej koncepcji męskości - nie mają dla nich tak istotnego znaczenia.

Kobiety, niezależnie od wieku, najczęściej przyznawały się do nieodpowiednich praktyk żywieniowych, głównie do nieregularnego spożywania posiłków: „jadam nieregularnie” (KM_2_24); „Albo nie jem cały boży dzień [...], potem rzucę się na jedzenie wieczorem (KSR_3_42)" oraz do wyboru złej jakości jedzenia, niezdrowych produktów i dań typu fast food: „no na pewno sposób odżywiania się np. rano kawa, to na pewno nie wpływa dobrze, albo cola [...] właśnie takie produkty właśnie żywnościowe, które mogą szkodzić później w przyszłości. Fast foody" (KM_7_28); „źle się odżywiam” (KSR_7_49), w tym - na co wskazywano zauważalnie często, szczególnie w grupie młodych - do nadmiernego spożywania słodyczy: ,jem słodycze” (KM_3_24; KM_10_30); „jem bardzo dużo słodyczy. Jestem absolutnie uzależniona od słodyczy" (KM_6_28); „Objadanie się słodyczami. To zdecydowanie” (KM_14_35); „No i jak się naopycham słodyczami, to sobie wtedy mówię, no Dorotka poszalałaś, znowu się najadłaś słodkiego" (KSR_8_53). Kilka spośród wypowiedzi kobiet wskazuje na to, iż niezdrowe praktyki żywieniowe mają znaczenie dla respondentek ze względu na ich negatywne oddziaływanie na sylwetkę. Niewłaściwa dieta nieodzownie jest bowiem asocjowana $\mathrm{z}$ nadwagą, czyli obfitym, nieatrakcyjnym ciałem, które zgodnie z patriarchalną koncepcją kobiecości powinno być szczupłe i zgrabne. Współcześnie najbardziej pożądany kulturowy wzorzec kobiecej figury w odniesieniu do rygorystycznych ograniczeń cielesności dobitnie charakteryzuje Sandra Lee Bartky: „Dzisiaj kobiece ciało, które jawi się jako masywne, silne czy też obfite, przyjmowane jest $\mathrm{z}$ niesmakiem. Modne jest ciało jędrne, 
o niewielkich piersiach i wąskich biodrach, tak szczupłe, że niemal zanikające; to sylwetka wydająca się właściwsza dla dorastającego chłopca albo dziewczynki w okresie dojrzewania niż dla dorosłej kobiety" (Bartky 2007: 53). Jak stwierdzają bowiem wprost respondentki, przyznając się do podejmowania działań sprzyjających tyciu lub dostrzegając taką zależność: „Jadam nieregularnie, mało piję, to jest niszczące dla organizmu, ale również może przyczynić się do otyłości. A otyłość jest zarówno niezdrowa, ale również nieestetycznie wygląda” (KM_2_24); „lubię czasami zjeść tak na tłusto, (a to jedzenie - przyp. aut.) odkłada się tam, gdzie nie powinno (KM_9_30)".

Uczestniczki wywiadów swobodnych zadeklarowały ponadto do niską aktywność fizyczną, co przede wszystkim negatywnie odbija się na ich sylwetce. Choć było to drugie najczęściej wymieniane niekorzystne dla wyglądu działanie, to należy zauważyć, że na brak ruchu sprzyjający pogorszeniu się figury wskazały wyłącznie kobiety młode oraz w średnim wieku: „Niestety nie ćwiczę [...]. Niestety nie uczęszczam na żadne fitnessy, które raczej są mi potrzebne, nie tylko dla wyglądu (KM_13_34)”; „żeby mieć dobrą fajną sylwetkę, to trzeba byłoby chodzić na siłownię codziennie, po kilka godzin się męczyć” (KSR_2_41); „jestem za gruba [...] nie uprawiam sportu, bo nie mam na to czasu ostatnio" (KST_7_49). Brak regularnego ruchu respondentki rzadziej wiązały z chęcią zachowania dobrej kondycji organizmu i sprawności fizycznej, co znajduje potwierdzenie również w badaniach społecznych w Polsce, z których wynika, że kobiety i mężczyźni odmiennie motywują swoje zaangażowanie w sport. Panie częściej niż panowie twierdzą, że ćwiczą dla urody - żeby dobrze wyglądać, mieć ładną sylwetkę (28\% wobec 19\%) (CBOS 2013a). Zdaniem Naomi Wolf piękno ciała stało się jednym z ważniejszych elementów konstruujących obowiązującą współcześnie patriarchalną koncepcję kobiecości. Nieustanna dbałość o dietę, restrykcyjne przeliczanie wartości energetycznej posiłków, mniej lub bardziej regularne ćwiczenia fizyczne oraz poddawanie się zabiegom kosmetycznym dla zachowania lub zdobycia nienagannej figury to przykłady działań służących utrzymaniu piękna kobiecego ciała. Podejmując szereg czynności związanych z troską o własną sylwetkę, kobiety chcą nie tylko przypodobać się mężczyznom i spełnić ich standardy estetyczne, ale również zostać społecznie dostrzeżone i zapobiec swojej marginalizacji (Wolf 2014). Sylwetka kobieca nadal jest poddawana większej presji piękna niż ciało męskie. Mężczyźni znacznie miej uwagi przykuwają do swojej diety, apetyt traktują jaką swoistą potrzebę ludzką, a ich korpulencja nie jest publicznie piętnowana, podczas gdy kobiece apetyty i ponadwymiarowe kształty stają się społecznym wyrazem wstydu. W rozmowach na temat nadwagi związanych $\mathrm{z}$ folgowaniem własnym pokusom jedzeniowym oraz brakiem 
ruchu kobiety ujawniają poczucie winy. Ideał piękna nie może wszak się obyć bez grzechu, co potwierdzają uczestniczki wywiadów:

No pizzę lubię jeść. [...] później żałuję, że to jadłam, bo się znowu ciężko (czuję - przyp. aut.), bo znowu tyle kalorii (KST_3_65). Nie podoba mi się [...] mój brzuch i moje powiedzmy uda, powiedzmy od pępka w dół do kolan, o, może te partie, które troszeczkę mniej, ale to jest też częściowo moja wina, bo nie ćwiczę. I straciło to wszystko na jędrności i atrakcyjności (KM_8_29).

Jak bowiem zauważa autorka Mitu urody, my, kobiety „czujemy się winne $\mathrm{z}$ powodu tuszy, ponieważ w głębi duszy zdajemy sobie sprawę $\mathrm{z}$ tego, że w warunkach mitu urody nasze ciała nie są nasze, lecz należą do społeczeństwa, szczupłość zaś nie jest prywatną estetyką, lecz społecznym wymogiem" (Wolf 2014: 237). To swego rodzaju kulturowe uwikłanie ciała w patriarchalnej koncepcji kobiecości trafnie podsumowuje psycholożka Ellyn Kaschack, zdaniem której „wygląd nie jest po prostu jej (kobiety - przyp. aut.) cechą, jak w przypadku mężczyzny; ona jest swoim wyglądem" (Kaschack 2001: 77).

Respondentki inaczej niż respondenci wyjaśniały swoją niską aktywność fizyczną, podając jako źródło subiektywną cechę własną - niemoc bądź niechęć, a nie czynnik obiektywny. Rzadziej wymawiały się brakiem czasu, a częściej przyznawały się do własnej słabości i lenistwa, co niewątpliwie wpisuje się w model patriarchalny, który zakłada orientację do wewnątrz, bierność i pasywność kobiety:

Nie potrafię się wziąć za siebie, nie potrafię trenować. Ćwiczenia i aktywność fizyczna nie sprawiają mi przyjemności (KM_2_24). Niestety nie ćwiczę [...]. Niestety nie uczęszczam na żadne fitnessy, które raczej są mi potrzebne, nie tylko dla wyglądu, ale i dla mojego zdrowia. (Próbowałam - przyp. aut.) kilkukrotnie, ale zawsze coś się zadziało, że albo nie miałam czasu, albo coś ze zdrowiem było nie tak, albo jeszcze czasami z lenistwa [...] i pochodziłam trochę, a potem rezygnowałam (KM_13_34). No właśnie z tym mam trochę problem, mam słaby zapał, słomiany, jak to się mówi, z tańcem faktycznie to bym chętnie wróciła, ale był czas, że chodziłam na aerobik i cały czas mam w głowie, żeby do tego wrócić, żeby jednak się trochę poruszać, ale nie jest to regularne, nie (KSR_2_41).

Inna z pań w średnim wieku, wyrażając swoje zatroskanie skłonnością do tycia, zauważa ponadto związek między metabolizmem a metryką, a także stanem zdrowia człowieka: „Przede wszystkim jestem świadoma, że w moim wieku już ciężej jest spalić, inne jest przyswajanie tego, co się je, inne przetwarzanie materii. Jestem też świadoma problemów z tarczycą, które miałam, które w każdej chwili mogą powrócić, z wagą, której nie chcę" (KSR_1_38). W społeczeństwie konsumpcyjnym 
i kulturze patriarchalnej szczupła sylwetka wiąże się z subiektywnym poczuciem atrakcyjności fizycznej kobiety, również $z$ atrakcyjnością seksualną. Automatycznie sprawia to, że wraz ze wzrostem masy ciała - towarzyszącym często procesowi starzenia się - kobiety tracą we własnych oczach, gdyż nadwaga oddala je od społecznego ideału piękna (Montemurro, Gillen 2013).

Kobiety w różnym wieku, znacznie częściej niż mężczyźni, odnotowały wpływ palenia papierosów na wygląd zewnętrzny i wyjaśniały, w jaki sposób działanie to niekorzystnie odbija się na przedmiocie postawy. Dostrzegano zarówno negatywne skutki biernego palenia dla wyglądu zewnętrznego i całego organizmu osoby przebywającej w towarzystwie palaczy: „jak się siedzi w jakichś zatłoczonych miejscach może dym papierosów, bierne palenie w jakiś sposób wpływa źle na nasz organizm” (KM_3_24), jak i niekorzystne oddziaływanie palenia czynnego przede wszystkim na kondycję skóry:

Palę czasem papierosy. To zdecydowanie niekorzystnie wpływa na mój wygląd [...], wysusza mi się bardzo skóra. Jeżeli palę papierosy i mam po prostu takie przesuszone ciało (KM_4_27). Kiedyś paliłam niestety papierosy, ale to już od dobrych dziesięciu albo więcej lat nie palę i to mi bardzo dobrze zrobiło. To jednak wie pani, niszczy bardzo, zwłaszcza kobiecą cerę i wygląd (KST_8_70).

Fakt, iż respondentki częściej i bardziej wyczerpująco opisywały nałóg palenia i przebywanie w bliskości dymu papierosowego jako zachowania negatywne względem ich wyglądu wynika z większej świadomości zdrowotnej kobiet oraz większej wiedzy na temat czynników niekorzystnie oddziałujących na cerę człowieka od wewnątrz i zewnętrznie, co jest zgodne z patriarchalną koncepcją ich płci. Kobiety bowiem częściej i z większą łatwością były w stanie powiązać zależność między zdrowiem a wyglądem zewnętrznym, poprzez odwoływanie się do zachowań związanych ze zdrowym stylem życia i wskazywaniem praktyk szkodliwych bezpośrednio dla zdrowia, a pośrednio dla wyglądu. Z podobnego względu respondentki częściej przyznawały się do spożywania alkoholu w niedużych ilościach i raczej okazjonalnie, ale ze świadomością ogólnego niekorzystnego wpływu napojów wyskokowych na organizm człowieka: „na pewno piję alkohol, nie w mega wielkich dawkach, ale tak, jest to szkodliwe (dla wyglądu - przyp. aut.)” (KM_10_30); „Czasami piję alkohol” (KSR_14_61); „Papierosów nie palę, no alkohol, no przecież jak się pójdzie na wesele, to trzeba za zdrowie młodych też wypić" (KST_14_86).

Mężczyźni zapytani o podejmowanie działań o negatywnym skutku dla ich aparycji nieco rzadziej niż biorące udział w badaniu kobiety 
przyznawali się do tego typu czynności. Znaczna część badanych, którzy odpowiedzieli na przedmiotowe pytanie, uznała, iż nie robi nic, co mogłoby mieć negatywny wpływ na ich powierzchowność. Pozostali wymieniali różne zachowania szkodzące ładnemu wyglądowi, a mimo to przez nich realizowane. Najpowszechniejszym grzechem - podobnie jak w przypadku kobiet - okazało się niewłaściwe, niezdrowe odżywianie się, w tym spożywanie posiłków typu fast food i słodyczy:

Nie przywiązuję uwagi do diety, chociaż staram się nieraz [...]. Bo nie umiem sobie odmówić na przykład, powiedzmy fast foodów, co jest niezdrowe (MM_9_30). Objadam się słodyczami, neurotycznie. Jak wpadnę w taką pułapkę, to mogę zeżreć całą czekoladę 10og. Albo objadam się fast foodami, wszystkie Big Maki, Whoopery nie są mi obce, wręcz przeciwnie. Także słodkie i fast foody to są dwie rzeczy (MSR_3_40).

Jednak krytyczne wypowiedzi mężczyzn w tym kontekście - w porównaniu do argumentów przytaczanych przez respondentki wywiadów swobodnych - były i rzadsze, i mniej zdecydowane, a dotyczyły przede wszystkim nieregularności i obfitości posiłków: „Nie, raczej nie (robię nic, co sprawia, że wyglądam gorzej - przyp. aut.), chyba. O ile traktować niezdrowe jedzenie czasem jako coś, co może zepsuć (wygląd - przyp. aut.)” (MM_1_21); „Słodycze, ale mi nie przeszkadzają w ogóle. Nie kojarzę dalej [...]" (MM_11_31).

Niektóre wypowiedzi świadczą nie tylko o większej nonszalancji, $\mathrm{z}$ jaką panowie traktują odżywianie, ale i zdecydowanie mniejszej dyscyplinie względem jakości i wartości energetycznej posiłków, które mają być przede wszystkim smaczne (o co również dbają kobiety - matka w przypadku jednego z młodych uczestników badania), a nie niskokaloryczne i pożywne, na co znacznie częściej zwracają uwagę osoby płci żeńskiej. Respondenci reprezentujący wszystkie kategorie wiekowe zdają się mniej zważać na kwestie dietetyki, mimo iż mają świadomość negatywnego wpływu niewłaściwego odżywiania się na wygląd człowieka:

Lubię polską kuchnię, żeby podsmażyć, lubię takie smażone. Wiem, że jest niezdrowe, ale lubię (MM_2_22). Jedno. Wraca się bardzo późno i to jedzenie wieczorne. Głód robi swoje (MSR_14_61). No, w życiu trzeba było różnych rzeczy spróbować, nie, już nie mówię o tych, o narkotykach, czy tego [...]. No ale, ja wiem, no [...] przede wszystkim jak młodszy człowiek był, jeszcze jak ja sam byłem na wyjeździe, to niezdrowe odżywianie, bo to wszystko bary, knajpy, naprędce, a co, się najeść (MST_6_66). Siedzenie przed telewizorem i do tego jakieś dobre piwo i ta pierś marynarza się powiększa (MST_11_71).

Powyższe wypowiedzi świadczą o dużej swobodzie, z jaką badani podchodzą do sposobu odżywania się, co wpisuje się w patriarchalny model 
ich płci, zgodnie z którym reżim odchudzania i ciągłej kontroli wagi i posiłków nie obowiązuje mężczyzn - ci mają większe społeczne przyzwolenie na folgowanie swoim pokusom w zakresie jedzenia. Kobieca otyłość wzbudza publiczne namiętności, podczas gdy tusza mężczyzny nie jest tak społecznie piętnowana i przez nich samych dostrzegana (tylko jeden $\mathrm{z}$ badanych, $\mathrm{z}$ najstarszej grupy wiekowej wskazał bezpośrednio na przyrost masy ciała, a ściślej na otyłość brzuszną w kontekście wysokokalorycznego alkoholu). W myśl koncepcji patriarchalnej krępa sylwetka mężczyzny nie zawsze niesie negatywne konotacje, świadcząc np. o materialnym dobrobycie i powodzeniu. Według Naomi Wolf kulturowy nacisk na szczupłość kobiet nie wynika z obsesji na punkcie urody dla niej samej, ale na punkcie kobiecego posłuszeństwa. Nadwaga czy przysadzista budowa, szczególnie u dojrzałych mężczyzn, nie ma znaczenia, gdyż męskość traktowana jako indywidualność może wyrażać się na różne sposoby, a dysproporcja społecznych oczekiwań względem ideałów sylwetki kobiecej i męskiej podkreśla relację władzy i podległości między płciami (Wolf 2014: 57, 236). Wzorzec ten wzmacniają również kobiety z najbliższego otoczenia badanych, pełniąc tradycyjną rolę matki - opiekunki i karmicielki, troszczącej się o zaspokojenie potrzeb żywieniowych i sytość posiłków ich podopiecznych, jak w przypadku jednego z cytowanych wyżej młodych respondentów.

Mężczyźni rzadziej przyznawali się również do korzystania z używek, dostrzegając ich ujemny wpływ na powierzchność. Spośród tych, którzy zadeklarowali palenie papierosów jako zły dla wyglądu nawyk, żaden nie dostrzegł negatywnych skutków bycia biernym palaczem. Wspominając o spożywaniu alkoholu, respondenci ze wszystkich grup wiekowych wskazywali raczej na szerszy trend związany z określonym „męskim” stylem życia, w który wpisuje się okazjonalne, sporadyczne „imprezowanie”: „Palę na imprezach [...] Spożywam alkohol, palę papierosy na imprezach” (MM_5_26); „Imprezy, imprezy całonocne z dużą ilością picia, kiedyś wystarczyło 2-3 godziny żeby się regenerować, teraz potrzebuję cały dzień, jak rano wstanę i w lustro popatrzę to masakra, napuchnięty, przekrwione oczy, straszne" (MSR_9_54). W świetle powyższej argumentacji daje się zauważyć, iż uczestnicy wywiadów swobodnych, w przeciwieństwie do badanych kobiet, nie dostrzegają w równie ostry sposób negatywnego wpływu środków odurzających na wygląd zewnętrzny człowieka i wydają się bagatelizować ich skutki dla urody jednostki.

Mężczyźni deklarowali ponadto niską aktywność fizyczną jako działanie, a raczej jego brak, które może mieć negatywny wpływ na ich wygląd. W nieco odmienny sposób uzasadniali jednak swoją bierność w tym zakresie. Częściej odwoływali się do czynników zewnętrznych, wymawiając się brakiem czasu związanym z aktywnością zawodową lub siedzącym 
trybem pracy, rzadziej zaś niską motywacją własną jako przyczyną wewnętrzną:

Uważam, że na przykład, no każdy powinien wykazywać jakiś ruch fizyczny, poćwiczyć, co może wydawać się też komiczne, bo na przykład ja, no tak średnio to robię, bo nawet [...] no nie mam czasu, jak mam czas to już nie mam ochoty, bo jestem zmęczony (MM_1_21). Czasami staram się (poruszać się - przyp. aut.). Nie ma czasami po prostu czasu [...], czyli jakby z braku czasu, można powiedzieć, że zaniedbuję swoje obowiązki, które sam sobie narzuciłem, ale staram się jakieś tam ćwiczenia podstawowe wykonywać. Czasami po prostu w domu sobie ćwiczę, jeżeli mi się przypomni i nie zapomnę (MM_4_24). Pewno to wszystkiego jest po trochę, na pewno łakomstwo i brak ruchu. Bo zależnie, gdy pracowałem, to ten brak ruchu, bo praca siedząca (MST_11_71).

W przypadku jednego respondenta brak czasu na uprawianie sportu wynikał z innej jeszcze „zewnętrznej” przyczyny, jaką było zaangażowanie się w nową rolę rodzicielską, która wymaga większej obecności ojca w domu: „Trochę z braku czasu zaprzestałem większej aktywności fizycznej, tak jak było kiedyś. Ze względu na to, że pojawiło się dziecko i więcej czasu spędzam w domu. Pewnie bym więcej ćwiczył, wygląd ciała by się poprawił" (MM_12_32).

Uwzględniając wiek respondentów w analizie wypowiedzi kobiet i mężczyzn, daje się zauważyć, że osoby młode, w średnim wieku i stare różnią się w swoich deklaracjach działań podejmowanych ze szkodą dla wyglądu zewnętrznego. W pierwszej kolejności omówione zostaną różnice w wypowiedziach względem przedmiotu postawy w zbiorowości kobiet, a następnie w zbiorowości mężczyzn w trzech wyodrębnionych kategoriach wiekowych.

Analizując wypowiedzi respondentek udzielonych na omawiane pytanie, od razu można dostrzec, iż reprezentantki najmłodszej kategorii wiekowej oceniły swoją postawę wobec wyglądu najbardziej krytycznie. W tej grupie badanych wszystkie uczestniczki zadeklarowały, że podejmują działania szkodliwe dla aparycji i wymieniały ich zdecydowanie najwięcej. W odróżnieniu od nich kobiety w wieku średnim i stare miały większą trudność ze sformułowaniem ewentualnych zarzutów do własnego zachowania względem wyglądu zewnętrznego. Niektóre ze starszych badanych uznały bowiem, że nie zdarza im się robić niczego, co mogłoby negatywnie odbić się na ich powierzchowności, a wiele kobiet z tej grupy wiekowej podało jedną, maksymalnie dwie niekorzystne w tym ujęciu czynności i to po chwilowym zastanowieniu.

Młode kobiety, rozważając działania podejmowane przez siebie na niekorzyść wyglądu, jako jedyne wskazały na własną nerwowość i uleganie 
sytuacjom stresowym, co negatywnie odbija się na ich wizerunku, wpływając również na procesy starzenia się skóry: „Przejmuję się niektórymi rzeczami, jestem nadal osobą nerwową i chyba już mi zmarszczki z tego powodu wychodzą” (KM_8_29); „Działania, jakie szkodzą mojemu wyglądowi to, to przede wszystkim dużo pracy, stresów, niewysypianie się i objadanie słodyczami, a w stresie objadanie się czym popadnie" (KM_13_34). Fakt, iż wyłącznie część młodych respondentek odwołała się do stresu jako czynnika szkodzącego wyglądowi, być może wynika z tego, że współcześnie w mediach więcej mówi się o negatywnych jego skutkach, stąd i większa świadomość uczestniczek z tej grupy wiekowej.

Ponadto pojawiły się również głosy świadczące o zmianie stosunku młodych kobiet do ich wyglądu. W badaniu wzięły udział i takie respondentki, które otwarcie i bez wyrzutów sumienia przyznały się do niskiej aktywności na rzecz dbania o własny wygląd, szczególnie w zakresie pielęgnacji skóry twarzy i ciała:

Mnie często brakuje czasu, bo mi go np. szkoda na te wszystkie zabiegi [...], bardzo często zapominam się smarować (twarz kremem - przyp. aut.), albo jestem po kąpieli zmęczona i mi się nie chce (KM_2_24). O ciało nie dbam w ogóle, nienawidzę balsamów, brzydzę się nimi i ogólnie wszystko się do mnie przykleja, więc o ciało prawie że w ogóle nie (dbam - przyp. aut.) (KM_6_28).

S.L. Bartky, odwołując się do rozważań Foucault na temat „praktyk dyscyplinarnych”, jakim poddawane jest ciało kobiet i mężczyzn, wpływając na ich postawy względem tego zasobu (Foucault 1998), analizowała katalog działań podejmowanych przez kobiety, które ich podatnym ciałom nadają płeć kulturową. Zdaniem amerykańskiej badaczki kulturowe wymogi dotyczące kobiet i kobiecego ciała i związane z nimi praktyki dobitnie pokazują, jak ciało to podlega kontroli społecznej i jest zarządzane przez surowy reżim kobiecości. Bartky wyróżnia trzy kategorie praktyk dyscyplinarnych, których celem jest: 1) wyprodukowanie ciała o określonym rozmiarze i kształcie, 2) wyrobienie specyficznych gestów, postaw i sposobów poruszania się, 3) przedstawienie ciała jako ozdobnej powierzchni (Bartky 2007). Mając na uwadze zarówno wyżej wymienione kategorie praktyk, jak i deklaracje respondentek o niepodejmowaniu działań pielęgnacyjnych oraz wcześniej przytoczone liczne wypowiedzi młodych respondentek karcących siebie za niewłaściwą dietę i brak aktywności fizycznej (sprzyjającym tyciu), można pokusić się o refleksję, że być może młode kobiety przestają godzić się na tę formę społecznego podporządkowania w kulturze patriarchalnej. Część z nich zaprzestaje realizacji owych praktyk dyscyplinarnych stanowiących element procesu, w ramach jakiego $\mathrm{z}$ ciała kobiety konstruowane jest „idealne ciało 
kobiece”, w które „został już wpisany podrzędny status” (Bartky 2007: 60) i odrzucając określony styl ciała, być może niebezpośrednio i nieświadomie kwestionuje normatywny porządek społeczny z nim asocjowany, deprecjonujący płeć żeńską.

Z drugiej jednak strony wciąż znacząca ilość kobiet młodych oraz tych w średnim wieku zdaje się być podporządkowana patriarchalnemu modelowi swojej płci i w sferze deklaratywnej obnaża chęć i powinność dążenia do ideału piękna. Zdaniem S. Nowaka, „kiedy komponent afektywny jest związany $\mathrm{z}$ komponentem behawioralnym postawy, znajduje to wyraz werbalny w postaci takich terminów normatywnych jak »należy«, "powinienem « lub terminów wolnych od normatywnego znaczenia jak "chcę«, "zamierzam« itp." (Nowak 1973: 33-34). W przypadku wypowiedzi respondentek wywiadów swobodnych na temat ich ciała i działań niekorzystnie na nie wpływających, zdecydowanie częściej pojawiały się deklaracje pierwszego typu, jako że ciało - przede wszystkim kobiece - jest efektem i miejscem oddziaływania surowych norm społecznych. Uczestniczki badania $\mathrm{z}$ grupy młodych i w średnim wieku mówiły bowiem:

Powinnam chyba uważać na to, co jem. Tak przeczytałam w gazecie (KM_1_21). Nie zawsze się zdrowo odżywiam, tak jak powinnam, bo to też jest różnie i z jakością tego jedzenia i z częstotliwością i ze wszystkim (KM_4_27). Nie powinnam jeść, bo za gruba jestem, a jem (KSR_15_62). Mało fizycznie się ruszam, brak tego ruchu i mam tego świadomość i tego nie robię, a powinnam bardziej (KSR_2_41). Powinnam mieć więcej ruchu (KSR_5_47).

Niemniej wypowiedzi dotyczące ewentualnie podejmowanych działań - w tym przypadku powstrzymywania się od określonego działania - sformułowane nakazowo jako powinności, również mogą świadczyć o niepoddawaniu się praktykom dyscyplinarnym przez kobiety młode i w średnim wieku. Ich deklaracje "niewypełniania obowiązku” względem własnego ciała mogą bowiem świadczyć nie tylko o znajomości korzyści płynących z wykonywania pewnych czynności, ale i o wewnętrznej odmowie realizacji tego kulturowego wzorca zachowań, choć odmowa ta niesie ze sobą koszt emocjonalny.

Respondentki wywiadów swobodnych reprezentujących wszystkie przedziały wiekowe przyznawały również, że niedobór snu może niekorzystnie oddziaływać na wygląd zewnętrzny. Co wydaje się jednak interesujące, jedynie kobiety $\mathrm{w}$ średnim wieku i stare wspominały o negatywnym wpływie niedostatecznej ilości snu wynikającej z przemęczenia, przepracowania:

Powinnam więcej wypoczywać, więcej spać, mniej ślęczeć nad książkami i w pomieszczeniach, więcej być na zewnątrz (KSR_5_47). Brak snu 
zdecydowanie i długa praca. Jeżeli mam dużo pracy, to jestem zmęczona. To właśnie to zmęczenie. No wynika to też z wieku, bo to kiedyś mogłam pracować 10 godzin i nie odczuwałam tego, a teraz jednak widać po mnie, że pracowałam i buzię mam szarą (KST_7_70).

Druga z cytowanych wyżej uczestniczek badania dostrzega również zależność między wyglądem a metryką, która przejawia się w wolniejszej regeneracji organizmu i skóry twarzy po wielogodzinnej pracy i nieprzespanej nocy. Wydaje się, iż podstawowym czynnikiem różnicującym odpowiedzi dotyczące niedoboru snu w zbiorowości kobiet jest prowadzony styl życia, związany również z niższą bądź wyższą aktywnością zawodową na określonym etapie życia. W przypadku młodych respondentek niewysypianie się wynika najczęściej z bardziej elastycznego trybu życia, który z racji braku zobowiązań rodzinnych pozwala na większą swobodę, w tym nocne rozrywki. Kobiety w średnim wieku i stare deklarowały intensywniejsze zaangażowanie zawodowe i konieczność godzenia kilku ról społecznych. Jedna kobieta w średnim wieku, opisując swoje złe praktyki żywieniowe, odwołała się do roli społecznej matki, opiekunki, która to wymaga na niej podporządkowanie się kaprysom smakowym dzieci i nie pozwala na zachowanie zdrowej diety: „Czasami jakieś frytki głupie, bez sensu zjem. Jakiś tam McDonald, bo dzieci jedzą, to ja też (KSR_3_42)”.

Z kolei najstarsze uczestniczki badania, na tle młodszych grup badanych, wyróżniły się wyraźnie niższym zainteresowaniem własnym wyglądem zewnętrznym, o czym świadczą wypowiedzi o niepodejmowaniu działań niekorzystnych dla powierzchowności oraz ich skromniejszy katalog w przypadku udzielenia odpowiedzi twierdzącej. Stare kobiety jako jedyne odwoływały się do sposobu ubierania się jako rodzaju zachowania negatywnie wpływającego na ich atrakcyjność. Wskazywały jednak na kwestie związane $\mathrm{z}$ dyskomfortem noszenia określonej odzieży (butów) oraz niedostosowanie ubioru do warunków pogodowych, a nie np. do sylwetki, typu urody czy trendów modowych:

Czasami po prostu, jak się robi bardzo zimno, a ja mam takie rękawiczki, że mi bardzo ręce zmarzną, to myślę, że mogłabym mieć cieplejsze rękawiczki [...]. Może nieraz założenie szpilek nie wpływa dobrze (KST_6_69). Czasami mam stopy zmęczone i muszę założyć nie te buty, które chciałabym założyć na przykład i wtedy no nie mam tego komfortu (KST_4_66).

Nacisk na względy praktyczne - pozornie na względy estetyczne - określonych elementów garderoby świadczy o instrumentalnym stosunku do odzieży obserwowanym w grupie starych respondentek, które najdłużej i najskuteczniej podlegały patriarchalnej socjalizacji, promującej uprzedmiotowienie kobiet. W pewnych sytuacjach wymaga się 
bowiem od kobiet określonego typu stroju, jak noszenie butów na obcasie, zgodnego z kanonem kobiecej mody, do jakiego najstarsze uczestniczki wywiadów starają się dostosować.

Analizując wypowiedzi mężczyzn należących do trzech kategorii wiekowych na temat podejmowanych przez nich działań szkodzących wyglądowi zewnętrznemu, również można dostrzec wiele różnic w ich stosunku do przedmiotu postawy.

Młodzi mężczyźni, podobnie jak młode kobiety, wyróżnili się najbardziej krytyczną oceną własnych zachowań, mających negatywny wpływ na atrakcyjność. Podawali przy tym inne przykłady czynności ujemnie odbijających się na ich powierzchowności. Tylko w tej grupie wiekowej badani zwrócili uwagę na szpecący nawyk obgryzania paznokci, m.in.: „Obgryzam paznokcie [...]. Dużo ludzi mi to mówi, że nie należy tego robić, to brzydko wygląda i biorę to trochę do serca i walczę ze sobą" (MM_4_24). Co wydaje się interesujące, młodzi wskazywali na tę manierę nie tyle z samokrytyki płynącej z wewnątrz, ile z racji jej powszechnego piętnowania przez osoby $z$ otoczenia.

Ponadto również $w$ grupie młodych mężczyzn - analogicznie jak to miało miejsce $\mathrm{w}$ grupie kobiet $\mathrm{z}$ tej kategorii wiekowej - wyjątkowo często wymieniano nieprawidłowe odżywianie się jako działanie szkodliwe dla wyglądu, podkreślając nadmierne spożycie słodyczy: „Jem bardzo dużo słodyczy, co jest niekorzystne dla wyglądu, jak i dla zdrowia (MM_12_32)”; „Tak, tak, uwielbiam słodycze i wcinam je na potęgę (MM_15_37)”. Można wnioskować ogólniej, iż najbardziej krytycznie do własnej diety odnosili się ludzie młodzi. W tej grupie wiekowej zdecydowanie najczęściej wymieniano zachowania żywieniowe zazwyczaj piętnowane przez dietetyków, co wpisuje się w szerszy trend obserwowany w społeczeństwie polskim. Zgodnie z badaniem CBOS negatywne oceny własnego sposobu odżywiania się są nieco częstsze wśród młodszych ankietowanych, w tym uczniów i studentów, niż wśród starszych (mających 55 lat i więcej). Co więcej, między posiłkami po słodkie przegryzki stosunkowo częściej sięgają ludzie młodzi niż respondenci ze starszych grup wiekowych (CBOS 2014).

Ponieważ najwięcej mężczyzn z grupy młodych wspomniało o złych praktykach żywieniowych i niskiej aktywności ruchowej w kontekście własnego ciała, można pokusić się o stwierdzenie, że perspektywa najmłodszego pokolenia respondentów w odniesieniu do własnego wyglądu ulega zmianie i oddala się od koncepcji patriarchalnej. Większość badanych $\mathrm{z}$ najmłodszej kategorii wiekowej w swoich odpowiedziach ujawniło wysokie poczucie własnej cielesności i zadeklarowało powinność utrzymania sylwetki o określonym kształcie. Jak zauważa Zbyszko Melosik, współczesna reklama coraz częściej jest adresowana do mężczyzn, 
przedstawiając ich wizerunki jako obiekty seksualnego pożądania, uprzedmiotawiając niejako również męskie ciało, co dotychczas dotyczyło wyłącznie kobiet. W społeczeństwie konsumpcyjnym jednostki są oceniane przez pryzmat swojej prezencji, przez co mężczyźni coraz częściej zaczynają zwracać uwagę na swoje ciało i stosować te same techniki upiększania co kobiety (Melosik 2002).

Choć młodość jako etap w życiu człowieka charakteryzuje się dużą swobodą działań, czasem wolnym na zainteresowania i rozrywki oraz „imprezowym” stylem życia w ogóle, to respondenci w średnim wieku oraz z grupy najstarszych częściej przyznawali się do spożywania alkoholu i palenia papierosów, wymieniając podejmowane przez siebie działania niekorzystne dla wyglądu, aniżeli ci z najmłodszej grupy badanych (wyłącznie jeden młody respondent przyznał się do korzystania z używek). Trudno wnioskować na temat młodych mężczyzn i hipotetyzować, czy jako młodsza generacja, prowadząc aktywne życie towarzyskie przy dobrym zdrowiu i młodzieńczym wyglądzie, nie dostrzegają podobnej zależności. Niemniej jednak, zgodnie z patriarchalną koncepcją męskości, z pewnością silniej oddziałującą na pokolenia starsze, wypowiedzi badanych w średnim wieku i starych obnażały ich niskie poczucie winy w tym względzie i (mimo świadomości pewnych negatywnych zależności) wyraźnie swobodny stosunek do danego nawyku, którego skutki nieświadomie minimalizowali: „Palę. I tylko to” (MSR_8_53); „Podobno picie alkoholu nie jest korzystne dla wyglądu, ale to ma tyle samo przeciwników, co i zwolenników” (MSR_1_38); „No co, działania, działania? Człowiek niby, wszystkie działania mogą być niekorzystne, tylko człowiek nie ma tego świadomości, nie? Pić alkohol też jest niekorzystne, nie?” (MST_6_66). Wyłącznie jeden respondent, spośród starych, wyraźnie potępił siebie za palenie papierosów, lecz wydaje się, że jego krytycyzm wynika z problemów zdrowotnych związanych z nałogiem, a nie z troski o wygląd: „Tylko najgorsze, że palę papierochy. To jest najgorsze [...]. Rano się kaszle itd. na zdrowie, po zawale tym bardziej” (MST_1_63).

Pojedyncze wypowiedzi w zbiorowości badanej mężczyzn dotyczyły również nadmiaru pracy i zmęczenia wynikającego z przepracowania, które zmniejszają atrakcyjność fizyczną. W tym tonie wypowiadali się jednak wyłącznie respondenci młodzi i w średnim wieku: „Czasami za dużo pracuję, No jak mam zarwany cały tydzień, to wyglądam jak zdjęty z krzyża (MM_5_26)”; „Za dużo pracuję, ale muszę [...]. Raczej nie podejmuję takich działań poza nadmierną pracą" (MSR_10_56). Żaden ze starych uczestników badania nie wskazał na taką zależność.

W odpowiedziach najstarszych respondentów pojawiły się z kolei pojedyncze argumenty dotyczące oszczędnej pielęgnacji ciała - w jednym przypadku wynikającej $\mathrm{z}$ ograniczonych potrzeb badanego: „Nie, no 
chyba nie [robię nic niekorzystnego dla wyglądu - przyp. aut.]. No, może córka mówi czasami, że mógłbym też jakichś kremów na twarz stosować. Ale woda, balsam po goleniu mi wystarczą. Jakoś mi te kremy nie pasują" (MST_8_70), na co zwraca uwagę kobieta z rodziny, powielając patriarchalny model męskości i relacji płci, zgodnie z którym mężczyzna ma mniejszą wiedzę na temat zabiegów upiększających i niższe poczucie obowiązku dbania o wygląd, podczas gdy kobieta - spokrewniona z nim, najbliżej związana - troszczy się o ten jego zasób za niego. W drugim przypadku było to działanie celowe, choć negatywne w skutkach, wynikające z braku obowiązkowości czy regularności w podejmowaniu działań pielęgnacyjnych: „No nie wiem, może tak jak nie jestem ze dwa, trzy dni ogolony. No bo, bo trzeba czasem dać i skórze odpocząć, no to wtedy może tak. Albo włosy już za długie. Bo trzeba je po prostu, częściej bywać tam u fryzjera z tym, z tą głową" (MST_9_70).

Rozważając wypowiedzi uczestników wywiadów swobodnych w podziale na kategorie wiekowe bez uwzględnienia zmiennej płci, daje się zaobserwować kilka ogólnych różnic ich stosunku wobec przedmiotu postawy. Najbardziej wyraźnie zaznaczają się - wspomniane już wcześniej - dysproporcje w krytycznej ocenie własnych zachowań mających negatywny wpływ na wygląd zewnętrzny. Najsurowiej oceniali siebie ludzie młodzi, niezależnie od płci, najłagodniej zaś osoby należące do grupy starych, które z najmniejszą swobodą wymieniały ewentualne działania negatywnie wpływające na ich atrakcyjność.

Młodzi zdecydowanie najczęściej ganili siebie za niewłaściwą dietę i nadmierną konsumpcję słodyczy, a w dalszej kolejności za brak ruchu. Choć niską aktywność fizyczną deklarowali reprezentanci każdej z grup wiekowych, oczywiste jest, iż wszelkiego rodzaju ruch wiąże się wiekiem i wydolnością organizmu, przez co sport jest domeną ludzi młodych (CBOS 2009a). Stąd i obydwa działania relatywnie często pojawiają się $\mathrm{w}$ wypowiedziach respondentów w wieku średnim, ale już marginalnie w grupie najstarszych badanych. Młodzi wydają się najbardziej skupieni na posiadaniu sylwetki o określonym kształcie - choć nie zawsze przekłada się to na regularną realizację praktyk dyscyplinarnych temu służących. Wydaje się, iż $\mathrm{w}$ tym przypadku różnice $\mathrm{w}$ postawach badanych reprezentujących różne przedziały wiekowe mogą wynikać zarówno z kulturowych koncepcji wieku: młodości, wieku średniego i starości, związanych ściśle $\mathrm{z}$ wizerunkiem ciała $\mathrm{w}$ określonym wieku biologicznym, jak i z różnic pokoleniowych wynikających z procesu socjalizacji w innych warunkach społeczno-kulturowych. Młodzi ludzie dorastali w świecie, w którym w mediach eksponowano kult ciała i młodości w szczególny sposób, przez co mają większą świadomość istoty tego zasobu dla funkcjonowania społecznego i odczuwają silniejszy imperatyw dbania o niego, szczególnie 
w kontekście otyłości. Mimo iż badani nieczęsto mówią wprost o powodach zatroskania niezdrową dietą oraz brakiem ruchu, można śmiało założyć, iż wymieniając te praktyki na szkodę własnego wyglądu zewnętrznego, mają na myśli groźbę przybrania na wadze i własną niechęć wobec tęgiej sylwetki. Kulturowy gorset szczupłego ciała, choć ciaśniej oplata kobiety, dotyczy również sylwetki męskiej, współcześnie bowiem coraz częściej stygmatyzuje społecznie przedstawicieli obu płci (Owen 2015).

Niewiele podobieństw znaleźć można wśród badanych należących do osób w wieku średnim. W tej grupie wiekowej - tak kobiety, jak mężczyźni - opisując podejmowane przez siebie działania o negatywnym wpływie na atrakcyjność własną, często odwoływali się do nadmiernego obciążenia pracą i ogólnego przemęczenia. Taki rozkład odpowiedzi wynika najprawdopodobniej z faktu, iż osoby w tym wieku znajdują się na szczytowym etapie swojej kariery zawodowej i muszą nierzadko pogodzić odmienne role społeczne w sferze publicznej i prywatnej - obowiązki zawodowe i role rodzicielskie. Być może również z tego względu w pojedynczych wypowiedziach reprezentantów wieku średniego pojawiły się refleksje dotyczące trudnych sytuacji życiowych i napięcia uniemożliwiającego zdrowy sen:

No w nocy nie śpię i wtedy wstaję z worami. Zdarza mi się, że są takie momenty, kiedy mało śpię i jak to jest dłużej, no to wtedy niekorzystnie wyglądam, jak trup (KSR_8_53). Generalnie braki snu zawsze się odbijają na tym, jak się wygląda. Czasami mówią o mnie, że wyglądam jakoś tak szaro, więc myślę, że to też jest skutek niedospania, a czasem też jest takiej sytuacji, w jakiej stawia życie, stresowych, ekstremalnych i tego typu historii (MSR_1_38).

Na podstawie wypowiedzi badanych można wychwycić tendencję, iż z wiekiem maleje znaczenie wyglądu zewnętrznego jako elementu kapitału społecznego człowieka, jak również spada krytycyzm względem działań własnych podejmowanych na niekorzyść utrzymania tego zasobu. Starzy respondenci wykazali bowiem najmniej surowy stosunek do przedmiotu postawy. Część z badanych w tej kategorii wiekowej stwierdziła, że nie zdarza im się robić niczego, co może źle wpływać na wygląd zewnętrzny. Pozostali, którzy wymienili działania o negatywnym skutku dla wyglądu, podali mniej przykładów w porównaniu do badanych z młodszych grup wiekowych. Wyłącznie osoby stare odwołały się do doboru niestosownego ubioru jako działania niekorzystnego. O ile jednak stare kobiety ujawniały podporządkowanie patriarchalnym rygorom kobiecego stroju, wymagającym m.in. noszenia obuwia na obcasie, o tyle jeden ze starych mężczyzn zwrócił uwagę na niewłaściwy dobór dodatków: „No na pewno, jak nieodpowiedni ubiór, a szczególnie, może nie tak ogólnie, tylko dodatki” (MST_13_77). Ten sam badany 
wnioskował ponadto, iż niestosowne zachowanie może obniżać atrakcyjność człowieka w oczach innych ludzi: „No negatywny wpływ to jest właśnie nieodpowiednie zachowanie. Będzie palił papierosa, rzuci i ktoś to zauważy na pewno i sobie pomyśli o nim nie najlepiej, prawda, źle świadczy już od razu" (MST_13_77). Z kolei jedna stara kobieta powiązała nie tyle własne postępowanie, co cechującą ją i trudną do opanowania skłonność do płaczu jako czynność o negatywnym skutku dla urody: „No, niestety mam oczy na mokrym miejscu. Jestem typem płaczki i zdecydowanie szkodzi mojemu wyglądowi, bo mam oczy czerwone jak królik" (KST_5_67). Powyższe wypowiedzi świadczą przede wszystkim o niższej refleksyjności ludzi starszych w kwestii ich wyglądu, który nie jest postrzegany stricte jako cielesność, o jaką należy w sposób szczególny się troszczyć. Ewentualne działania szkodzące wizerunkowi człowieka nie dotyczą bowiem praktyk dyscyplinujących sylwetkę i zabiegów pielęgnacyjnych w takiej intensywności, jak to przejawia się w wypowiedziach respondentów z grupy młodych i w wieku średnim. Ludzie młodzi skupiają się na wybranych elementach wyglądu zewnętrznego człowieka, przede wszystkim na ciele, które stanowi atrybut urody zarówno młodej kobiety, jak i młodego mężczyzny. Starzy ludzie postrzegają atrakcyjność człowieka w szerszej perspektywie, zwracając uwagę np. na ubiór, zachowanie czy własne cechy osobowe, a deklarowane przez nich działania na niekorzyść aparycji wydają się być częściej skorelowane z dolegliwościami i fizycznym dyskomfortem (u starych kobiet zmęczenie nóg w butach na obcasie, zmarznięte dłonie bez rękawiczek), i szerzej ze zdrowiem aniżeli z wyglądem, o czym świadczą wypowiedzi o: „niezdrowym odżywianiu się”, „, niezdrowym biernym paleniu” czy paleniu czynnym źle wpływającym „na zdrowie” szczególnie „po zawale”.

Podsumowując analizę wypowiedzi kobiet i mężczyzn reprezentujących trzy kategorie wiekowe: młodości, wieku średniego i starości na temat podejmowanych przez siebie działań, które negatywnie wpływają na wygląd zewnętrzny, można wnioskować, iż kobiety są bardziej świadome znaczenia wyglądu jako zasobu jednostki, a tym samym bardziej refleksyjne i krytyczne, jeśli chodzi o swoje zachowania względem tego zasobu. Liczne i różnorodne czynności o skutkach niekorzystnych dla ciała i prezencji człowieka, do jakich wykonywania przyznawały się kobiety - wobec mniej zróżnicowanych odpowiedzi mężczyzn na ten temat - świadczą przede wszystkim o większej aktywności kobiet względem przedmiotu postawy. Mężczyźni prezentują mniejsze zainteresowanie troską o własny wygląd, który nie jest podstawą definicyjną ich wzorca płci. W przekroju kategorii wiekowych okazuje się jednak, że płeć słabo różnicuje postawy ludzi młodych i nieznacznie wpływa na postawy osób w starszym wieku. Młode respondentki i respondenci w swoich 
wypowiedziach jawią się jako androgyniczni, gdyż zarówno kobiety, jak i mężczyźni z najmłodszej grupy badanych mają wysoką świadomość negatywnych skutków realizowanych bądź nierealizowanych przez siebie praktyk dyscyplinujących ciało i tym samym prezentują aktywne postawy wobec wyglądu. Kobiety i mężczyźni w średnim wieku i starzy, wymieniając skromniejszy katalog działań niekorzystnych dla wyglądu, ujawniają bardziej pasywny stosunek do przedmiotu postawy. Należy jednak zauważyć, że realizując patriarchalne wzorce kobiecości i męskości, kobiety z dwóch starszych kategorii wiekowych wykazały większą refleksyjność w tym zakresie aniżeli ich rówieśnicy. 